\title{
The Essential Oil-Bearing Plants in the United Arab Emirates (UAE): An Overview
}

\author{
Suzan Marwan Shahin ${ }^{1,2}$, Abdul Jaleel ${ }^{1}$ and Mohammed Abdul Muhsen Alyafei ${ }^{1, *}$ \\ 1 Department of Integrative Agriculture, College of Agriculture and Veterinary Medicine, \\ United Arab Emirates University, Al Ain 15551, United Arab Emirates; drsuzan.s@uaqu.ac.ae (S.M.S.); \\ abdul.jaleel@uaeu.ac.ae (A.J.) \\ 2 Research and Development Head, Umm Al Quwain University, Umm Al Quwain 536, United Arab Emirates \\ * Correspondence: mohammed.s@uaeu.ac.ae
}

Citation: Shahin, S.M.; Jaleel, A.; Alyafei, M.A.M. The Essential Oil-Bearing Plants in the United Arab Emirates (UAE): An Overview. Molecules 2021, 26, 6486. https:// doi.org/10.3390/molecules26216486

Academic Editors: Marcello Iriti and Md. Moshfekus Saleh-E-In

Received: 18 September 2021

Accepted: 18 October 2021

Published: 27 October 2021

Publisher's Note: MDPI stays neutral with regard to jurisdictional claims in published maps and institutional affiliations.

Copyright: (c) 2021 by the authors. Licensee MDPI, Basel, Switzerland. This article is an open access article distributed under the terms and conditions of the Creative Commons Attribution (CC BY) license (https:// creativecommons.org/licenses/by/ $4.0 /)$.

\begin{abstract}
Essential Oils (EOs) are expensive hydrocarbons produced exclusively by specific species in the plant kingdom. Their applications have deep roots in traditional herbal medicine, which lacks scientific evidence. Nowadays, more than ever, there is a growing global interest in researchbased discoveries that maintain and promote health conditions. Consequently, EOs became a much attractive topic for both research and industry, with revenues reaching billions of dollars annually. In this work, we provide key guidance to all essential oil-bearing plants growing in the United Arab Emirates (UAE). The comprehensive data were collected following an extensive, up-to-date literature review. The results identified 137 plant species, including indigenous and naturalized ones, in the UAE, citing over 180 published research articles. The general overview included plant botanical names, synonyms, common names (Arabic and English), families and taxonomic authority. The study acts as a baseline and accelerator for research, industry and discoveries in multiple disciplines relying on essential oil-bearing plants.
\end{abstract}

Keywords: arid lands; essential oil-bearing plants; indigenous and naturalized plants; United Arab Emirates (UAE)

\section{Introduction}

Globally, the essential oils (EOs) industry creates billions of dollars of revenue annually. Therefore, more attention has been given recently to this sector, as a natural primary resource for phytochemicals. Indeed, the EOs industry has a wide range of enormous applications in various fields, such as pharmaceuticals, aromatherapy, healthcare, cosmetics, food flavoring, food preservation and the fragrance industry [1].

Briefly, EOs are concentrated phytochemicals comprised mostly of terpenes, oxygenated terpenes, sesquiterpenes and oxygenated sesquiterpenes [2,3]. EOs are volatiles associated with a characteristic aroma resulting from the complex interaction between hundreds of volatiles. These hydrophobic compounds are produced exclusively from certain plant species as secondary metabolites, acting as defense phytochemicals [4].

In fact, EOs applications have deep roots in old traditional practices, in which they were a natural resource to treat infections and sicknesses for hundreds of years [3,4]. However, such traditional practices lack scientific validation, and thus have to be remarkably studied and tested, looking for scientific justification. The studies about essential oils from UAE plants and their biological activities are scanty when compared to other research in plant-based fields. There are studies such as extraction of essential oil of Haplophyllum tuberculatum [5], Teucrium stocksianum [6], Pulicaria glutinosa [7], Cleome amblyocarpa [4] and Moringa peregrina [8] from the United Arab Emirates.

The main objective of this work is to provide key guidance to all EO-bearing plants indigenous and naturalized to the United Arab Emirates (UAE), which included highlights on all available EO-bearing plant species, their families, botanical names, common names 
(Arabic and English) and taxonomic authority. It worth mentioning that this is the first record in the literature that provides the essential oil-bearing plants of the UAE. The value of such data will accelerate research, knowledge and discoveries in multiple disciplines (e.g., environment, biology, chemistry, chemical engineering, pharmacognosy, pharmacology and healthcare). The findings are key knowledge to justify the rich ethnomedicinal applications of the aromatic medicinal plants of the UAE. Additionally, this study will be supportive to decision-makers in strategic and sustainable planning for essential oil-bearing plants of the region.

\section{Study Location}

This work covered the UAE as a study location (land area of around $82,880 \mathrm{~km}^{2}$ ), which is located in the arid Western parts of Asia at the southeast end of the Arabian Peninsula on the Arabian/Persian Gulf (Latitude $22^{\circ} 30^{\prime}$ and $26^{\circ} 10^{\prime} \mathrm{N}$ and longitude $51^{\circ}$ and $\left.56^{\circ} 25^{\prime} \mathrm{E}\right)$.

\section{Weather Conditions and Soil Analysis}

The study location belongs to the arid zone; the climate is characterized by high summer temperatures (around $46^{\circ} \mathrm{C}$ ) and high humidity rates along the two coastal lines. It is characterized by a low and irregular precipitation rate $(60$ to $160 \mathrm{~mm})$ [9].

The soil is classified as sandy sodic soil with a high permeability rate, low water holding capacity, low moisture content and low fertility rate $[9,10]$. Soil salinity is one of its major problems, especially in the coastal lines [11].

Conventional surface water resources include seasonal floods, springs and Falajes. The only groundwater resource comes from aquifers [12]. The high dependency on groundwater aquifers with low recharging rates causes both groundwater depletion and saline water intrusion, creating concerns that aquifer supplies may soon be depleted [13] and indicating a challenging future for the sustainability of the agricultural sector [12].

\section{Data Collection Methodologies}

To best of our knowledge, all existed references "online and hardcopy printed sources" related to the UAE flora were reviewed to collect the botanical names of all the UAE indigenous and naturalized plants, which were around 800 plant species. The references included Batanouny [14], Western [15], Tanira et al., [16], Wasfi [17], Karim [18], Emirates Natural History Group [19], Böer and Chaudhary [20], Jongbloed et al., [21], Brown and Sakkir [22], Aspinall [23], Zayed Complex for Herbal Research and Traditional Medicine (ZCHRTM) [24], Handa et al., [25], Karim and Dakheel [26], Mousa and Fawzi [27], Sakkir et al., [28], Fawzi and Ksiksi [29], Hurriez [30], Feulner [31], El-Keblawy et al., [32] and the Environmental Agency of Abu Dhabi [33,34].

After collecting the botanical names and synonyms of all documented Emirati indigenous and naturalized plants, each plant was subjected individually to an extensive literature review. The literature was collected using the online resource "Google Scholar", in which all the published works indexed in "Scopus", "Web of Science" and "PubMed". Each plant was searched individually using the keywords "botanical name/synonyms + essential oil". To the best of our knowledge, all existed published articles were carefully screened and over 180 of the latest articles were cited.

\section{Results and Discussions}

\subsection{A Comprehensive Overview}

All the indigenous and naturalized plants of the study location were evaluated and the result was establishing a full list of all Emirati EO-bearing plants (Table 1), including an overview of 137 Emirati EO-bearing plants belonging to 46 families, all cited based on up-to-date literature (over 180 references). Meaning that, EO-bearing plants comprise 17\% of the estimated 800 indigenous and naturalized plants. 
Table 1. An overview of indigenous and naturalized essential oil-bearing plants of the UAE.

\begin{tabular}{|c|c|c|c|c|c|c|}
\hline & Family & Binomial & $\begin{array}{l}\text { Taxonomic } \\
\text { Authority }\end{array}$ & $\begin{array}{l}\text { Synonyms "Syn." and/or Common } \\
\text { Names (English "Eng." and/or } \\
\text { Arabic "Arb.") }\end{array}$ & $\begin{array}{c}\text { Reference } \\
\text { Categorizing the } \\
\text { Plant as Essential } \\
\text { Oil-Bearing Plant }\end{array}$ & $\begin{array}{l}\text { Reference for UAE } \\
\text { Nativity/ } \\
\text { Natuaralization }\end{array}$ \\
\hline 1 & $\begin{array}{l}\text { Aizoaceae/Ficoidaceae } \\
\text { (Mesembryanthemum, } \\
\text { carpetweed family) }\end{array}$ & $\begin{array}{c}\text { Sesuvium } \\
\text { portulacastrum }\end{array}$ & $\mathrm{L}$. & $\begin{array}{l}\text { Sesuvium verrucosum Raf. (Eng. } \\
\text { Shoreline purslane, sea } \\
\text { purslane, sesuvium) }\end{array}$ & [35] & {$[21,22]$} \\
\hline 2 & \multirow{3}{*}{$\begin{array}{l}\text { Amaranthaceae } \\
\text { (Cockscomb family) }\end{array}$} & Achyranthes aspera & L. & $\begin{array}{l}\text { (Eng. Prickly chaff flower) (Arb. Saif } \\
\text { el-jinn, umdhrese, sehem, ar-ray, } \\
\text { mahoot, na'eem, wazer) }\end{array}$ & [36] & {$[21,22]$} \\
\hline 3 & & Aerva javanica & $\begin{array}{l}\text { (Burm. f.) Juss. ex } \\
\text { Schul. }\end{array}$ & $\begin{array}{l}\text { (Eng. Desert cotton, snow bush) } \\
\text { (Arb. Al ara', twaim, efhe, tirf) }\end{array}$ & {$[37,38]$} & {$[15,18,21-25,27,28,32]$} \\
\hline 4 & & Chenopodium album & $\mathrm{L}$. & $\begin{array}{l}\text { (Eng. Lamb's quarters, melde, } \\
\text { goosefoot, fat-hen, white goosefoot) } \\
\text { (Arb. Shulah, 'aifajan, } \\
\text { rokab al-jamal) }\end{array}$ & [39] & {$[15,21,22]$} \\
\hline 5 & $\begin{array}{l}\text { Anacardiaceae (The cashew, } \\
\text { sumac family) }\end{array}$ & Pistacia khinjuk & Stocks. & & [40] & [21] \\
\hline 6 & \multirow{7}{*}{ Apiaceae/Umbelliferae } & Ammi majus & $\mathrm{L}$. & $\begin{array}{l}\text { (Eng. Bishop's flower, bishop's } \\
\text { weed) (Arb. Sannout, sheeh, khilla } \\
\text { "khilla sheitani", nayniya) }\end{array}$ & {$[41]$} & {$[15,21,22,28]$} \\
\hline 7 & & Anethum graveolens & $\mathrm{L}$. & (Eng. Dill Weed) & [42] & {$[15,21]$} \\
\hline 8 & & Ducrosia anethifolia & (DC.) Boiss. & (Arb. Basbaz, haza) & [43] & {$[15,21,22,28]$} \\
\hline 9 & & Pimpinella eriocarpa & Banks and Sol. & (Arb. Kusaybirah) & [44] & {$[15,21]$} \\
\hline 10 & & Pimpinella puberula & (DC.) Boiss. & & [45] & {$[15,21]$} \\
\hline 11 & & Scandix pecten-veneris & L. & $\begin{array}{l}\text { (Eng. Shepherd's-needle, Crib } \\
\text { Gwener) (Arb. Mushet) }\end{array}$ & [46] & {$[15,21]$} \\
\hline 12 & & Torilis leptophylla & (L.) Reichenb.f. & $\begin{array}{l}\text { (Syn. Caucalis leptophylla) (Eng. } \\
\text { Bristle-fruited hedge-parsley) }\end{array}$ & [47] & {$[21]$} \\
\hline 13 & \multirow{4}{*}{ Apocynaceae (Dogbane family) } & Catharanthus roseus & (L.) G. Don & $\begin{array}{l}\text { (Syn. Vinca rosea) (Eng. } \\
\text { Madagascar periwinkle) }\end{array}$ & [42] & [15] \\
\hline 14 & & Nerium oleander & $\mathrm{L}$. & $\begin{array}{l}\text { (Syn. Nerium mascatense) (Eng. } \\
\text { Rosebay, olender) (Arb. } \\
\text { Defla, haban) }\end{array}$ & [48] & {$[15,21,22,28]$} \\
\hline 15 & & Plumeria rubra & $\mathrm{L}$. & (Eng. Nosegay, frangipan) & [49] & {$[15,21,22,28]$} \\
\hline 16 & & Calotropis procera & (Aiton) W.T. Aiton & $\begin{array}{l}\text { (Eng. Apple of Sodom, Sodom } \\
\text { apple, stabragh, kapok tree, king's } \\
\text { crown, rubber bush, rubber tree, } \\
\text { Sodom's apple milkweed) (Arb. } \\
\text { 'ushar, shakjr, 'asur, ashkhar "askar") }\end{array}$ & [50] & {$[21,22,28]$} \\
\hline 17 & $\begin{array}{l}\text { Arecaceae (Palmae, palmaceae } \\
\text { family, palm trees) }\end{array}$ & Phoenix dactylifera & $\mathrm{L}$. & $\begin{array}{l}\text { (Eng. Date palm, date palm tree) } \\
\text { (Arb. Nakhl, amm-amm) }\end{array}$ & [51] & {$[15,21,22,28]$} \\
\hline 18 & \multirow{12}{*}{$\begin{array}{c}\text { Asteraceae/Compositae/ } \\
\text { Anthemideae (Sunflower family) }\end{array}$} & $\begin{array}{c}\text { Anthemis } \\
\text { odontostephana }\end{array}$ & Boiss. & (Arb. O'qhowan) & {$[52]$} & {$[15,21]$} \\
\hline 19 & & Artemisia sieberi & Besser & (Eng. Wormwood) & [53] & [28] \\
\hline 20 & & Calendula arvensis & $\mathrm{L}$. & $\begin{array}{c}\text { (Eng. Field marigold) (Arb. Ain el } \\
\text { baqr, eqhwan-asfar, hanwa, } \\
\text { hanuwa) }\end{array}$ & [54] & {$[15,21]$} \\
\hline 21 & & Cichorium intybus & $\mathrm{L}$. & $\begin{array}{l}\text { (Eng. Blue daisy, blue dandelion, } \\
\text { blue sailors, blue weed, bunk, } \\
\text { coffeeweed) (Arb. hindibaa bareeya, } \\
\text { chicoria) }\end{array}$ & [55] & {$[15,21,28]$} \\
\hline 22 & & Conyza bonariensis & (L.) Cronq. & $\begin{array}{c}\text { (Syn. Conyza linifolia (Willd.) Tackh) } \\
\text { (Eng. Flax-leaf Fleabane, Wavy-leaf } \\
\text { Fleabane, hairy fleabane) (Arb. } \\
\text { hashishat el-jebal, tebaq) }\end{array}$ & [56] & {$[21,22]$} \\
\hline 23 & & Eclipta prostrata & $\mathrm{L}$. & $\begin{array}{l}\text { (Syn. Eclipta alba (L.) Hassk.) (Eng. } \\
\text { False daisy, Trailing eclipta ). (Arb. } \\
\text { Sa'ada, sauweid, masadate) }\end{array}$ & [57] & {$[15,21]$} \\
\hline 24 & & Grantia aucheri & Boiss. & No Information & [58] & [27] \\
\hline 25 & & Launaea nudicaulis & (L.) Hook. f. & $\begin{array}{l}\text { (Eng. Hawwa Baqrah ara, hindabah } \\
\text { ara, huwah ara, naked launea) (Arb. } \\
\text { Huwah al ghazal, safara, huwah, } \\
\text { hindabah) }\end{array}$ & {$[59,60]$} & {$[15,21,22]$} \\
\hline 26 & & Matricaria aurea & (Loefl.) Sch. Bip. & $\begin{array}{l}\text { (Eng. Golden chamomile) } \\
\text { (Arb. Babunaj) }\end{array}$ & [61] & {$[21,28]$} \\
\hline 27 & & Matricaria chamomilla & $\mathrm{L}$. & $\begin{array}{l}\text { (Syn. Matricaria recutita) (Eng. } \\
\text { Chamomile, camomile, } \\
\text { german chamomile) }\end{array}$ & [62] & [63] \\
\hline 28 & & Pluchea arabica & $\begin{array}{l}\text { (Boiss.) Qaiser } \\
\text { and Lack }\end{array}$ & (Eng. Pluchea) (Arb. godot) & [64] & {$[28]$} \\
\hline 29 & & Pluchea dioscoridis & (L.) DC. & $\begin{array}{l}\text { (Syn. Conyza dioscoridis (L.) Desf., } \\
\text { Baccharis dioscoridis L.) (Eng. } \\
\text { Ploughmans spikenard, marsh } \\
\text { fleabane) (Arb. Sahikee, barnof) }\end{array}$ & [65] & {$[15,21,22]$} \\
\hline
\end{tabular}


Table 1. Cont

\begin{tabular}{|c|c|c|c|c|c|c|}
\hline & Family & Binomial & $\begin{array}{l}\text { Taxonomic } \\
\text { Authority }\end{array}$ & $\begin{array}{l}\text { Synonyms "Syn." and/or Common } \\
\text { Names (English "Eng." and/or } \\
\text { Arabic "Arb.") }\end{array}$ & $\begin{array}{c}\text { Reference } \\
\text { Categorizing the } \\
\text { Plant as Essential } \\
\text { Oil-Bearing Plant }\end{array}$ & $\begin{array}{c}\text { Reference for UAE } \\
\text { Nativity/ } \\
\text { Natuaralization }\end{array}$ \\
\hline 30 & \multirow{10}{*}{$\begin{array}{c}\text { Asteraceae/Compositae/ } \\
\text { Anthemideae (Sunflower family) }\end{array}$} & Pluchea ovalis & (pers.) DC. & (Eng. Woolly camphor-weed) & [66] & {$[15,21]$} \\
\hline 31 & & $\begin{array}{l}\text { Pseudognaphalium } \\
\text { luteo-album }\end{array}$ & (L.) H. and B. & $\begin{array}{l}\text { (Syn. Gnaphalium luteo-album L.) } \\
\text { (Eng. Cudweed) (Arb. } \\
\text { sabount el'afrit) }\end{array}$ & [67] & {$[21,22]$} \\
\hline 32 & & Pulicaria arabica & (L.) Cass. & $\begin{array}{c}\text { (Syn. Inula arabica L./Pulicaria elata } \\
\text { Boiss./Pulicaria laniceps Bornm.) } \\
\text { (Arb. Iqat, abu 'ain safra) }\end{array}$ & [68] & [21] \\
\hline 33 & & Pulicaria glutinosa & Jaub. and Spach & $\begin{array}{l}\text { (Arb. Thal, fal, shajarat fal, } \\
\text { muhayda, mithidi, shajarat } \\
\text { al-mithidi, shneena, zayyan) }\end{array}$ & [7] & {$[15,21,22]$} \\
\hline 34 & & Pulicaria inuloides & (Poir.) DC. & No information & [69-71] & {$[21]$} \\
\hline 35 & & Pulicaria undulata & (L.) C.A. Meyer & $\begin{array}{l}\text { (Syn. Pulicaria crispa (Forssk.) } \\
\text { Benth.) (Eng. Crisp-leaved fleabane) } \\
\text { (Arb. Gathgeth, jithjath, 'urayfijan) }\end{array}$ & [72] & {$[15,21,22]$} \\
\hline 36 & & Rhanterium epapposum & Oliv. & (Eng. Rhanterium) (Arb. Arfaj) & [73] & {$[15,21,22]$} \\
\hline 37 & & Senecio glaucus & $\begin{array}{l}\text { L. ssp. } \\
\text { coronopifolius } \\
\text { (Maire) Al. }\end{array}$ & $\begin{array}{l}\text { (Syn. Senecio desfontanei Druce) (Eng. } \\
\text { Maire alexander, buck's horn } \\
\text { groundsel) (Arb. Qorreis, murair, } \\
\text { zamlooq, shakhees, rejel al ghurab) }\end{array}$ & [74] & {$[15,21,22]$} \\
\hline 38 & & Seriphidium herba-alba & (Asso) Sojak & $\begin{array}{c}\text { (Syn. Artemisia herba-alba } \\
\text { Asso/Artemisia inculta Del) (Eng. } \\
\text { Wormwood, white wormwood) } \\
\text { (Arb. Ata, ghata, shih) }\end{array}$ & {$[75,76]$} & [21] \\
\hline 39 & & Sphagneticola trilobata & & $\begin{array}{l}\text { (Syn. Wedelia paludosa DC.) (Eng. } \\
\text { Singapore daisy, creeping-oxeye, } \\
\text { trailing daisy, wedelia) }\end{array}$ & [77] & [15] \\
\hline 40 & Bignoniaceae (Bignonias family) & Jacaranda mimosifolia & D. Con & $\begin{array}{l}\text { (Eng. Jacaranda, blue jacaranda, } \\
\text { black poui, fern tree) }\end{array}$ & [78] & [15] \\
\hline 41 & \multirow{3}{*}{$\begin{array}{l}\text { Boraginaceae (Borage, } \\
\text { forget-me-not family) }\end{array}$} & Arnebia linearifolia & DC. & No Information & [79] & [21] \\
\hline 42 & & Heliotropium europaeum & $\mathrm{L}$. & $\begin{array}{c}\text { (Syn. Heliotropium lasiocarpum Fisch. } \\
\text { and Mey.) (Eng. European } \\
\text { heliotrope, european turnsole) } \\
\text { (Arb. Karee) }\end{array}$ & [80] & {$[15,21,22]$} \\
\hline 43 & & Trichodesma africanum & & $\begin{array}{l}\text { (Syn. Trichosdesma africana (L.) R. Br.) } \\
\text { (Eng. African barbbell) }\end{array}$ & [81] & [15] \\
\hline 44 & \multirow{9}{*}{$\begin{array}{l}\text { Brassicaceae/Cruciferae (Cress, } \\
\text { mustard family) }\end{array}$} & Capsella bursa-pastoris & (L.) Medik. & $\begin{array}{l}\text { (Eng. Shepherd's-purse) (Arb. Kis } \\
\text { al ra'y) }\end{array}$ & [82] & {$[15,21,22]$} \\
\hline 45 & & Cardaria draba & (L.) Desv. & $\begin{array}{c}\text { (Syn. Lepidium draba) (Eng. } \\
\text { Whitetop, hoary cress) (Arb. lislis) }\end{array}$ & [83] & {$[21,22]$} \\
\hline 46 & & Coronopus didymus & (L.) Sm. & $\begin{array}{l}\text { (Eng. Lesser swine-cress) (Arb. } \\
\text { Rashad al-barr) }\end{array}$ & [84] & {$[21,22]$} \\
\hline 47 & & Erucaria hispanica & & $\begin{array}{l}\text { (Eng. Spanish pink mustard, } \\
\text { erucaria myagroides) (Arb. } \\
\text { Khezaam, saleeh, kromb al sahra) }\end{array}$ & [79] & {$[15,21]$} \\
\hline 48 & & Eruca sativa & Mill. & $\begin{array}{l}\text { (Eng. Salad rocket, rucola, rucoli, } \\
\text { rugula, colewort, roquette, garden } \\
\text { rocket, rocket) (Arb. Girgir, jirjeer) }\end{array}$ & [85] & {$[15,21,22,28]$} \\
\hline 49 & & Savignya parviflora & (Delile) Webb & $\begin{array}{c}\text { (Eng. Jaljalan, kanad al barr, } \\
\text { gulgulan, girgees, small whorled } \\
\text { cheeseweed) (Arb. Khzaymah, } \\
\text { al-thee, jerjees "girgees", gongolan } \\
\text { "qunqulan, jaljelan, } \\
\text { galeigelan, bithman") }\end{array}$ & [86] & {$[15,21,22]$} \\
\hline 50 & & Schimpera arabica & $\begin{array}{l}\text { Hochst. and } \\
\text { Steud. }\end{array}$ & & [79] & {$[15,21]$} \\
\hline 51 & & Sinapsis arvensis & $\mathrm{L}$. & $\begin{array}{l}\text { (Syn. Sinapis arvensis L.) (Eng. } \\
\text { Charlock, charlock mustard, } \\
\text { wild mustard) }\end{array}$ & [87] & {$[15,21]$} \\
\hline 52 & & Sisymbrium irio & $\mathrm{L}$. & $\begin{array}{c}\text { (Eng. London rocket) (Arb. } \\
\text { Howairah, shelyat, figl el-gamal, } \\
\text { harrah) قراص حمار }\end{array}$ & [88] & {$[21,28]$} \\
\hline 53 & \multirow{2}{*}{$\begin{array}{l}\text { Capparaceae/Capparidaceae } \\
\text { (Caper family) }\end{array}$} & Capparis cartilaginea & Decne. & $\begin{array}{l}\text { (Eng. Caper) (Arb. Qubr, sediru, } \\
\text { ashflah, lezaf "losef, lusfeh, ewsawf) }\end{array}$ & [89] & {$[15,21,22,26,28]$} \\
\hline 54 & & Capparis spinosa & $\mathrm{L}$. & $\begin{array}{l}\text { (Eng. Caper bush, flinders rose) (Arb. } \\
\text { Kobar, lasafa, fakouha, shawk mal } \\
\text { homar, shafallah, delayeer, dabayee) }\end{array}$ & {$[89,90]$} & {$[15,21,22,28]$} \\
\hline 55 & $\begin{array}{l}\text { Caryophyllaceae/Illecebraceae } \\
\text { (Carnation family) }\end{array}$ & Stellaria media & (L.) Vill. & $\begin{array}{l}\text { (Eng. Chickweed, common } \\
\text { chickweed, chickenwort, craches, } \\
\text { maruns, winterweed, lawn weed) } \\
\text { (Arb. Meshit, hashishet } \\
\text { el-qizaz, qizaza) }\end{array}$ & [91] & {$[15,21]$} \\
\hline 56 & Casuarinaceae (Beefwood family) & Casuarina equisetifolia & & $\begin{array}{l}\text { (Syn. Casuarina equistetifolia J.R. and } \\
\text { G. Forst.) (Eng. Rhu, casuarina tree) }\end{array}$ & {$[92,93]$} & [15] \\
\hline 57 & $\begin{array}{l}\text { Cistaceae (Rock-rose, rock } \\
\text { rose family) }\end{array}$ & $\begin{array}{l}\text { Helianthemum } \\
\text { kahiricum }\end{array}$ & Delile & $\begin{array}{l}\text { (Eng. Rock rose, sun rose) (Arb. } \\
\text { Ragroog, qsasah, hashma) }\end{array}$ & [94] & {$[15,21,22]$} \\
\hline
\end{tabular}


Table 1. Cont.

\begin{tabular}{|c|c|c|c|c|c|c|}
\hline & Family & Binomial & $\begin{array}{l}\text { Taxonomic } \\
\text { Authority }\end{array}$ & $\begin{array}{l}\text { Synonyms "Syn." and/or Common } \\
\text { Names (English "Eng." and/or } \\
\text { Arabic "Arb.") }\end{array}$ & $\begin{array}{c}\text { Reference } \\
\text { Categorizing the } \\
\text { Plant as Essential } \\
\text { Oil-Bearing Plant }\end{array}$ & $\begin{array}{c}\text { Reference for UAE } \\
\text { Nativity/ } \\
\text { Natuaralization }\end{array}$ \\
\hline 58 & \multirow{4}{*}{ Cleomaceae } & Cleome amblyocarpa & Barr. and Murb. & $\begin{array}{l}\text { (Syn. Cleome africana, Cleome arabica, } \\
\text { Cleome daryoushian) (Eng. Spider } \\
\text { flower) (Arb. Adheer, durrayt } \\
\text { an-na'am, khunnayz, ufaynah) }\end{array}$ & {$[4,95]$} & {$[21]$} \\
\hline 59 & & Cleome brachycarpa & Vahl ex DC. & $\begin{array}{l}\text { (Syn. Cleome vahliana Farsen) (Arb. } \\
\text { Za'af, mkhaysah) }\end{array}$ & [96] & {$[15,21]$} \\
\hline 60 & & Cleome droserifolia & Del. & $\begin{array}{l}\text { (Syn. Roridula droserifolia Forssk.) } \\
\text { (Eng. Cleome herb) }\end{array}$ & [97] & [15] \\
\hline 61 & & Cleome gynandra & L. & $\begin{array}{c}\text { (Syn. Gynandropsis gynandra } \\
\text { (L.)Briq.) (Eng. Shona cabbage, } \\
\text { African cabbage) (Arb. Abu qarim) }\end{array}$ & [98] & [21] \\
\hline 62 & Combretaceae & Terminalia catappa & L. & $\begin{array}{l}\text { (Eng. Indian almond-wood, bastard } \\
\text { almond, andaman badam) } \\
\text { هليلج هندي }\end{array}$ & [99] & [15] \\
\hline 63 & \multirow[t]{2}{*}{$\begin{array}{l}\text { Convolvulaceae (Morning glory, } \\
\text { bindweed family) }\end{array}$} & Ipomoea aquatica & Forssk. & $\begin{array}{l}\text { (Eng. Kang kong, water } \\
\text { convolvulus, water spinach, swamp } \\
\text { cabbage, ong choy, hung tsai, rau } \\
\text { muong) السبانخ المائي }\end{array}$ & [100] & {$[21,22]$} \\
\hline 64 & & Ipomoea obscura & & $\begin{array}{l}\text { (Eng. Obscure morning-glory, small } \\
\text { white morning glory) }\end{array}$ & {$[101,102]$} & [21] \\
\hline 65 & \multirow[b]{2}{*}{ Cucurbitaceae (Gourd family) } & Momordica charantia & L. & $\begin{array}{l}\text { (Eng. Bitter melon, bitter gourd, } \\
\text { bitter squash, balsam-pear) }\end{array}$ & {$[103,104]$} & {$[24]$} \\
\hline 66 & & Luffa acutangula & (L.) Roxb. & $\begin{array}{l}\text { (Eng. Angled luffa, chinese okra, } \\
\text { dish cloth gourd, ridged gourd, } \\
\text { sponge gourd, vegetable gourd, } \\
\text { strainer vine, ribbed loofah, silky } \\
\text { gourd, ridged gourd, silk gourd, } \\
\text { sinkwa towelsponge) }\end{array}$ & {$[103,105]$} & [21] \\
\hline 67 & \multirow{3}{*}{ Cyperaceae (Sedges family) } & Cyperus arenarius & Retz. & $\begin{array}{l}\text { (Syn. Bobartia indica L.) (Eng. } \\
\text { dwarf sedge) }\end{array}$ & [106] & {$[21,22,34]$} \\
\hline 68 & & Cyperus conglomeratus & Rottb. & $\begin{array}{l}\text { (Eng. Cyperus, mali tamachek saad) } \\
\text { (Arb. Thenda. Ayzm, chadrum, } \\
\text { qassis, rasha) }\end{array}$ & [107] & {$[15,21,22,34]$} \\
\hline 69 & & Cyperus rotundus & $\mathrm{L}$. & $\begin{array}{l}\text { (Eng. Coco-grass, Java grass, nut } \\
\text { grass, purple nut sedge, red nut } \\
\text { sedge, Khmer kravanh chruk) (Arb. } \\
\text { Sa'ed, sa'ed al hammar, hasir) }\end{array}$ & [108] & {$[15,21,22,28,34]$} \\
\hline 70 & \multirow{4}{*}{$\begin{array}{l}\text { Euphorbiaceae (Spurge, castor, } \\
\text { euphorbias family) }\end{array}$} & Euphorbia helioscopia & $\mathrm{L}$. & $\begin{array}{l}\text { (Eng. Sun spurge, madwoman's } \\
\text { milk) (Arb. Haleeb al-diba, sa'asa, } \\
\text { tanahout, kerbaboosh) }\end{array}$ & [109] & {$[21,22]$} \\
\hline 71 & & Euphorbia hirta & $\mathrm{L}$. & $\begin{array}{l}\text { (Eng. Asthma plant, asthma weed, } \\
\text { pill-bearing spurge) (Arb. Libbein, } \\
\text { demeema, menthra) }\end{array}$ & [110] & {$[15,21,22]$} \\
\hline 72 & & Euphorbia peplus & $\mathrm{L}$. & $\begin{array}{l}\text { (Syn. Euphorbia peplis L.) (Eng. Petty } \\
\text { spurge, radium weed, cancer } \\
\text { weed, milkweed) } \\
\text { (Arb. Khunaiz) }\end{array}$ & [111] & {$[21,22,28]$} \\
\hline 73 & & Ricinus communis & $\mathrm{L}$. & $\begin{array}{l}\text { (Eng. Castor oil) (Arb. 'Arash, } \\
\text { ash'asheh, khasaab, khirwa } \\
\text { "khurwa'a", junijund, tifsh) }\end{array}$ & [112] & {$[15,21,22,28]$} \\
\hline 74 & \multirow{9}{*}{$\begin{array}{l}\text { Fabaceae/Leguminosae/ } \\
\text { Papilionoideae (Pea family) }\end{array}$} & Alhagi maurorum & Medik. & $\begin{array}{l}\text { (Syn. Alhagi graecorum Boiss.) (Eng. } \\
\text { Camelthorn, camelthorn-bush, } \\
\text { caspian manna, persian mannaplant) } \\
\text { (Arb. Shwaika, agool, heidj) }\end{array}$ & {$[113,114]$} & {$[15,24]$} \\
\hline 75 & & Lotus halophilus & $\begin{array}{l}\text { Boiss. and } \\
\text { Spruner }\end{array}$ & $\begin{array}{c}\text { (Eng. Greater bird's foot trefoi) (Arb. } \\
\text { Horbeith "hurbuth", garn al ghazal, } \\
\text { 'asheb al ghanem) }\end{array}$ & {$[79,89]$} & {$[15,21,22]$} \\
\hline 76 & & Medicago polymorpha & L. & $\begin{array}{l}\text { (Eng. California burclover, toothed } \\
\text { bur clover, toothed medick, } \\
\text { burr medic) }\end{array}$ & [115] & {$[15,21,22]$} \\
\hline 77 & & Medicago sativa & $\mathrm{L}$. & (Eng. Alfalfa, lucerne) & [116] & [15] \\
\hline 78 & & Rhynchosia minima & (L.) DC. & $\begin{array}{l}\text { (Eng. least snout-bean, } \\
\text { burn-mouth-vine and jumby bean) } \\
\text { (Arb. Baql) }\end{array}$ & [117] & {$[15,21,22]$} \\
\hline 79 & & Tephrosia persica & Boiss. & $\begin{array}{l}\text { (Syn. Tephrosia apollinea (Delile) DC.) } \\
\text { (Arb. Dhafra, omayye, nafal) }\end{array}$ & [118] & {$[15,21,32]$} \\
\hline 80 & & Trigonella hamosa & $\mathrm{L}$. & $\begin{array}{l}\text { (Eng. Branched fenugreek, Egyptian } \\
\text { fenugreek) (Arb. Nafal, qutifa, } \\
\text { qirqas, darjal, eshb al-malik, qurt) }\end{array}$ & [79] & {$[15,21,22]$} \\
\hline 81 & & Ononis sicula & Guss. & - & [119] & [21] \\
\hline 82 & & Acacia nilotica & (L.) Delile & $\begin{array}{l}\text { (Syn. Acacia Arabica (Lam.) Willd.) } \\
\text { (Eng. Gum arabic tree, babul/kikar, } \\
\text { Egyptian thorn, sant tree, al-sant, } \\
\text { prickly acacia) (Arb. Sunt garath } \\
\text { "kurut", babul, tulh. Fruit: karat) }\end{array}$ & {$[120,121]$} & {$[15,21,22,26,28]$} \\
\hline
\end{tabular}


Table 1. Cont.

\begin{tabular}{|c|c|c|c|c|c|c|}
\hline & Family & Binomial & $\begin{array}{l}\text { Taxonomic } \\
\text { Authority }\end{array}$ & $\begin{array}{l}\text { Synonyms "Syn." and/or Common } \\
\text { Names (English "Eng." and/or } \\
\text { Arabic "Arb.") }\end{array}$ & $\begin{array}{c}\text { Reference } \\
\text { Categorizing the } \\
\text { Plant as Essential } \\
\text { Oil-Bearing Plant }\end{array}$ & $\begin{array}{l}\text { Reference for UAE } \\
\text { Nativity/ } \\
\text { Natuaralization }\end{array}$ \\
\hline 83 & \multirow{2}{*}{$\begin{array}{c}\text { Fabaceae/Leguminosae/ } \\
\text { Papilionoideae (Pea family) }\end{array}$} & Acacia tortilis & (Forssk.) Hayne & $\begin{array}{l}\text { (Eng. Umbrella thorn) (Arb. Samr } \\
\text { "samur", salam) }\end{array}$ & {$[120,122]$} & {$[15,21,22,26,32]$} \\
\hline 84 & & Prosopis farcta & $\begin{array}{l}\text { (Banks and } \\
\text { Sol.) Mac. }\end{array}$ & $\begin{array}{c}\text { (Eng. Dwarf mesquite, syrian } \\
\text { mesquite) (Arb. Yanbut, } \\
\text { agoul, awsaj) }\end{array}$ & [123] & {$[15,21,22]$} \\
\hline 85 & Frankeniaceae & Frankenia pulverulenta & L. & $\begin{array}{l}\text { (Eng. European Frankenia, } \\
\text { European sea heath) (Arb. Molleih, } \\
\text { hamra (hmaira), Umm thurayb) }\end{array}$ & [124] & {$[21,22]$} \\
\hline 86 & Geraniaceae (Geranium family) & Erodium cicutarium & $\begin{array}{l}\text { (L.) L Her. } \\
\text { Ex Aiton }\end{array}$ & $\begin{array}{l}\text { (Eng. Redstem filaree, redstem } \\
\text { stork's bill, common } \\
\text { stork's-bill, pinweed) }\end{array}$ & [125] & [21] \\
\hline 87 & $\begin{array}{c}\text { Hypericaceae } \\
\text { (St. Johnswort family) }\end{array}$ & Hypericum perforatum & & (Eng. St.John's wort) & [126] & [30] \\
\hline 88 & Iridaceae (Irises family) & $\begin{array}{l}\text { Gynandriris } \\
\text { sisyrinchium }\end{array}$ & (L.) Parl. & $\begin{array}{l}\text { (Syn. Iris sisyrinchium L., Moraea } \\
\text { sisyrinchium (L.) Ker Gawl.) (Eng. } \\
\text { Barbary Nut, mountain iris) (Arb. } \\
\text { Khowais, su'ayd, 'unsayl) }\end{array}$ & [127] & {$[15,21]$} \\
\hline 89 & \multirow{11}{*}{$\begin{array}{l}\text { Lamiaceae/Labiatae (Mint, } \\
\text { deadnettle family) }\end{array}$} & Lallemantia royleana & (Benth.) Benth. & (Eng. Bian bing cao) & [128] & [21] \\
\hline 90 & & Mentha spicata & & spicata (Eng. Spearmint, spear mint) & [129] & {$[63,130]$} \\
\hline 91 & & Ocimum forsskaolii & Benth. & $\begin{array}{l}\text { (Syn. Ocimum forskolei Benth.) (Eng. } \\
\text { Rehan, sawma) } \\
\text { (Arb. Basil) }\end{array}$ & [131] & {$[15,21,28]$} \\
\hline 92 & & Salvia aegyptiaca & L. & $\begin{array}{l}\text { (Eng. Egyptian sage) (Arb. Ra'al, } \\
\text { na'aim, ghbeisha, shajarat al } \\
\text { ghazal, khizam) }\end{array}$ & [132] & {$[15,21,22,24,28]$} \\
\hline 93 & & Salvia macilenta & Boiss. & $\begin{array}{l}\text { (Eng. Khizama) (Arb. Khmayzah } \\
\text { lethnay, bithman) }\end{array}$ & [133] & {$[15,21,22]$} \\
\hline 94 & & Salvia macrosiphon & Boiss. & (Arb. Shajarat Al Ghazal) & [134] & {$[15,21]$} \\
\hline 95 & & Salvia mirzayanii & $\begin{array}{l}\text { Rech.f. } \\
\text { and Esfandiari }\end{array}$ & & [135] & [21] \\
\hline 96 & & Salvia spinosa & L. & (Arb. Shajarat al-ghazal) & [136] & {$[21,22]$} \\
\hline 97 & & Teucrium polium & $\mathrm{L}$. & (Eng. Felty germander) & {$[137,138]$} & {$[21,28]$} \\
\hline 98 & & Teucrium stocksianum & Boiss. & $\begin{array}{c}\text { (Eng. Jadah, yadah, Ja'adah) (Arb. } \\
\text { Ya'dah, brair) }\end{array}$ & {$[6,139]$} & {$[15,21,22,24,28,32]$} \\
\hline 99 & & Zataria multiflora & Boiss. & (Eng. Za'atar, shirazi thyme) & {$[140,141]$} & [24] \\
\hline 100 & Liliaceae (lily family) & Dipcadi erythraeum & Webb and Berth. & $\begin{array}{l}\text { (Synonym: Dipcadi serotinum (L.) } \\
\text { Medik.) (Eng. Brown Lily, } \\
\text { Hyacinthus serotinus, mesailemo, } \\
\text { besailemo) (Arb. Busalamo, ansel, } \\
\text { misselmo, shkal). }\end{array}$ & [142] & {$[15,21,22]$} \\
\hline 101 & Lythraceae & Lawsonia inermis & $\mathrm{L}$. & $\begin{array}{l}\text { (Eng. Egyptian Privet, the henna } \\
\text { tree, mignonette tree) }\end{array}$ & [143] & {$[15,21,22,24,28]$} \\
\hline 102 & $\begin{array}{l}\text { Malvaceae/Tiliaceae } \\
\text { (Mallows family) }\end{array}$ & Corchorus depressus & (L.) Stocks. & $\begin{array}{l}\text { (Eng. Mulakhiyah al bar, sutaih, } \\
\text { rukbat al jamal) (Arb. Matara, } \\
\text { seluntah, mulukhia el bar, waikai) }\end{array}$ & [144] & {$[15,21,22]$} \\
\hline 103 & Moringaceae (Moringa family) & Moringa peregrina & (Forssk.) Fiori & $\begin{array}{l}\text { (Eng.Wild drumstick tree) (Arb. } \\
\text { Shu', yasar, baan, 'aweyr, bayreh, } \\
\text { terfaal, yayn) }\end{array}$ & [8] & [21] \\
\hline 104 & \multirow[t]{2}{*}{ Myrtaceae (Myrtle family) } & $\begin{array}{l}\text { Eucalyptus } \\
\text { camaldulensis }\end{array}$ & Dehnh. & $\begin{array}{l}\text { (Syn. Eucalyptus camaldulensis Dehn.) } \\
\text { (Eng. River red gum, red gum, } \\
\text { Murray red) }\end{array}$ & [145] & [15] \\
\hline 105 & & Eucalyptus pimpiniana & Maiden & $\begin{array}{l}\text { "Eng. Pimpin mallee, red } \\
\text { dune mallee" }\end{array}$ & [146] & [15] \\
\hline 106 & \multirow{2}{*}{ Oleaceae (Olive family) } & Jasminum sambac & (L.) Ait. & الفل (Eng. Arabian jasmine) & [147] & [15] \\
\hline 107 & & Olea europaea & $\begin{array}{l}\text { L. subsp. } \\
\text { Cuspidata }\end{array}$ & $\begin{array}{l}\text { (Wall. Ex G. Don) ciferri (Eng. Olive } \\
\text { tree) (Arb. 'Itm, mitan) }\end{array}$ & [148] & [21] \\
\hline 108 & \multirow{2}{*}{$\begin{array}{l}\text { Plantaginaceae } \\
\text { (Plantain family) }\end{array}$} & Plantago amplexicaulis & Cav. & $\begin{array}{l}\text { (Eng. Ispaghula, Plantain, rablat al } \\
\text { mistah, lesan al hamal) (Arb. } \\
\text { gerenwa, rabl, aynsum, khannanit } \\
\text { an na'ja) }\end{array}$ & [79] & {$[15,21,22]$} \\
\hline 109 & & Plantago boissieri & $\begin{array}{l}\text { Hausskn. and } \\
\text { Bornm. }\end{array}$ & (Arb. Rabl, yanam) & [149] & {$[15,21,22]$} \\
\hline 110 & \multirow{3}{*}{$\begin{array}{c}\text { Poaceae/Gramineae (Gramineae, } \\
\text { true grasses family) }\end{array}$} & Cenchrus ciliaris & $\mathrm{L}$. & $\begin{array}{l}\text { (Eng. Buffelgrass, African foxtail } \\
\text { grass, sand-burr) (Arb. Sadat, } \\
\text { khadir, thumum, gharaz, } \\
\text { drab, labaytad) }\end{array}$ & [79] & {$[15,21,32,34]$} \\
\hline 111 & & Cynodon dactylon & (L.) Pers. & $\begin{array}{l}\text { (Eng. Bermudagrass, dubo, dog's } \\
\text { tooth grass, Bahama grass, devil's } \\
\text { grass, couch grass) (Arb. Thi'il, negil } \\
\text { "najiel”, najm, sheel, bizait) }\end{array}$ & {$[150,151]$} & {$[15,21,34]$} \\
\hline 112 & & Desmostachya bipinnata & (L.) Stapf & $\begin{array}{l}\text { (Eng. Halfa grass, big cordgrass, salt } \\
\text { reedgrass) (Arb. Halfa, hafla } \\
\text { and sanaiba) }\end{array}$ & [152] & {$[15,21,34]$} \\
\hline
\end{tabular}


Table 1. Cont

\begin{tabular}{|c|c|c|c|c|c|c|}
\hline & Family & Binomial & $\begin{array}{l}\text { Taxonomic } \\
\text { Authority }\end{array}$ & $\begin{array}{c}\text { Synonyms "Syn." and/or Common } \\
\text { Names (English "Eng." and/or } \\
\text { Arabic "Arb.") }\end{array}$ & $\begin{array}{c}\text { Reference } \\
\text { Categorizing the } \\
\text { Plant as Essential } \\
\text { Oil-Bearing Plant }\end{array}$ & $\begin{array}{l}\text { Reference for UAE } \\
\text { Nativity } / \\
\text { Natuaralization }\end{array}$ \\
\hline 113 & \multirow{4}{*}{$\begin{array}{l}\text { Poaceae/Gramineae (Gramineae, } \\
\text { true grasses family) }\end{array}$} & Lolium rigidum & Gaudin & $\begin{array}{l}\text { (Eng. Wimmera ryegrass, Swiss rye } \\
\text { grass) (Arb. Hayyaban, shilm, } \\
\text { ziwan, simbil, rabiya) }\end{array}$ & [153] & {$[15,21]$} \\
\hline 114 & & $\begin{array}{l}\text { Cymbopogon } \\
\text { commutatus }\end{array}$ & (Steud.) Stapf & $\begin{array}{c}\text { (Syn. Cymbopogon parkeri Stapf.) } \\
\text { (Eng. Incense grass, Rosagrass) (Arb. } \\
\text { Alklathgar, sakhbar, hamra, } \\
\text { idhkhir, khasaab) }\end{array}$ & [154] & {$[15,21,22,34]$} \\
\hline 115 & & Cymbopogon jwarancusa & $\begin{array}{l}\text { subsp. olivieri } \\
\text { (Boiss.) }\end{array}$ & (Eng. Oilgrass, iwarancusa grass) & [155] & {$[20,21]$} \\
\hline 116 & & $\begin{array}{l}\text { Cymbopogon } \\
\text { schoenanthus }\end{array}$ & (L.) Spreng. & $\begin{array}{l}\text { (Eng. Camel grass, camel's hay, } \\
\text { fever grass, geranium grass, West } \\
\text { Indian lemon grass) (Arb. } \\
\text { Adlghar, hashmah) }\end{array}$ & {$[155,156]$} & {$[15,21,22,24,28,34]$} \\
\hline 117 & \multirow{2}{*}{$\begin{array}{c}\text { Polygonaceae } \\
\text { (buckwheat family) }\end{array}$} & Calligonum comosum & L'Her. & $\begin{array}{l}\text { (Synonym: Calligonum polygonoides } \\
\text { subsp. comosum (L'Her.) Soskov) } \\
\text { (Eng. Fire bush) (Arb. Arta, } \\
\text { waragaat as-shams, 'abal, dhakar) }\end{array}$ & [157-159] & {$[15,21,22,24,28]$} \\
\hline 118 & & Rumex vesicarius & L. & $\begin{array}{l}\text { (Eng. Sorrel, Bladder dock, Rosy } \\
\text { dock, Ruby dock) (Arb. Humayth } \\
\text { "hommeid, hummad, } \\
\text { hambad", hambasees) }\end{array}$ & [160] & {$[15,21,22,24,28]$} \\
\hline 119 & $\begin{array}{l}\text { Ranunculaceae (Buttercup, } \\
\text { crowfoot family) }\end{array}$ & Nigella sativa & $\mathrm{L}$. & (Eng. Black seed, black cumin) & [161] & [24] \\
\hline 120 & \multirow[b]{2}{*}{ Rhamnaceae (Buckthorn Family) } & Ziziphus jujuba & Mill. & (Eng. Chinese date, jujube) & [162] & [15] \\
\hline 121 & & Ziziphus spina-christi & (L.) Willd. & $\begin{array}{l}\text { (Eng. Christ's thorn jujube, Christ's } \\
\text { torn, nabk tree) (Arb. Sidr, ber, } \\
\text { 'ilb, zaqa) }\end{array}$ & [163] & {$[15,21,22,28]$} \\
\hline 122 & $\begin{array}{l}\text { Rubiaceae (coffee, Rue, madder, } \\
\text { bedstraw family) }\end{array}$ & Galium tricornutum & Dandy & $\begin{array}{l}\text { (Eng. Rough corn bedstraw, } \\
\text { roughfruit corn bedstraw and } \\
\text { corn cleavers) }\end{array}$ & [164] & [21] \\
\hline 123 & \multirow[t]{2}{*}{ Rutaceae (Rue, citrus family) } & $\begin{array}{l}\text { Haplophyllum } \\
\text { tuberculatum }\end{array}$ & (For.) A. Juss. & $\begin{array}{l}\text { (Syn. Haplophyllum arabicum) (Eng. } \\
\text { Sazab, zeita, kheisa, mesaika) (Arb. } \\
\text { Srayu'u asraw, mekhiseh “Umm } \\
\text { musayka”, kirkhan, zuqayqah, } \\
\text { furaythah, zifra al-tais, sinam al-tais. } \\
\text { Khaisa, sjaharet al-ba'ud, sjaharet } \\
\text { al-ghazal, tafar al-tays, khokhawot, } \\
\text { mekhisat al-hamr) }\end{array}$ & [165] & {$[15,21,22,28]$} \\
\hline 124 & & Ruta chalepensis & $\mathrm{L}$. & (Eng. Rue, fringed rue) & [166] & {$[22,24]$} \\
\hline 125 & Salvadoraceae/Salourloruceae & Salvadora persica & $\mathrm{L}$. & $\begin{array}{l}\text { (Eng. Toothbrush tree, mustard tree, } \\
\text { mustard bush) (Arb. Suwak, rak, } \\
\text { ('arak, yeharayk, ehereek) }\end{array}$ & {$[167,168]$} & {$[15,21,22,24,28]$} \\
\hline 126 & Solanaceae (Nightshade family) & Withania somnifera & (L.) Dunal. & $\begin{array}{l}\text { (Eng. Ashwagandha, Indian } \\
\text { ginseng, poison gooseberry, winter } \\
\text { cherry) (Arb. Babu "ebab", sumal } \\
\text { far, haml balbool, morgan, } \\
\text { simm, frakh) }\end{array}$ & [169] & {$[21]$} \\
\hline 127 & Tamaricaceae (Tamarisk family) & Tamarix nilotica & (Ehrenb.) Bunge & $\begin{array}{c}\text { (Syn. Tamarix mannifera (Ehrenb.) } \\
\text { Bunge (h)/Tamarix arabica Bunge) } \\
\text { (Eng. Nile tamarisk) (Arb. tarfa", } \\
\text { "terfat", athl) }\end{array}$ & [170] & {$[15,21,22,26,28]$} \\
\hline 128 & \multirow{5}{*}{$\begin{array}{l}\text { Verbenaceae (Verbena, } \\
\text { vervain family) }\end{array}$} & Clerodendrum inerme & (L.) Gaertn. & (Eng. Vanajai, garden quinine) & [171] & [15] \\
\hline 129 & & Lantana camara & $\mathrm{L}$. & (Eng. Tickberry) & {$[172,173]$} & [15] \\
\hline 130 & & Phyla nodiflora & (L.) Greene & $\begin{array}{l}\text { (Syn. Phyla nodiflora / Lippia (Phyla) } \\
\text { nodiflora (L.) Greene/Phylain } \\
\text { nodiflora/Lippia nodiflora (L.) } \\
\text { Mychx.) (Arb. Berbin al-jedi, herum } \\
\text { dezen, thayyel sini, lebbia, farfakh) }\end{array}$ & [174] & {$[15,21]$} \\
\hline 131 & & Vitex agnus-castus L. & $\mathrm{L}$. & (Eng. Chaste tree) & {$[175,176]$} & [20-22] \\
\hline 132 & & Avicennia marina & (Forssk.) Vierh. & $\begin{array}{l}\text { (Syn. Avicennia marina L.) (Eng. Grey } \\
\text { mangrove, white mangrove) (Arb. } \\
\text { Qurm, gurm) }\end{array}$ & [177] & {$[15,21,22,28]$} \\
\hline 133 & Violaceae & Viola odorata & $\mathrm{L}$. & $\begin{array}{l}\text { (Eng. Sweet violet, garden violet, } \\
\text { common blue violet, viol, viotea) }\end{array}$ & {$[178,179]$} & [24] \\
\hline 134 & \multirow{2}{*}{ Zingiberaceae (Ginger family) } & Alpinia galanga & (L.) $\mathrm{Sw}$ & $\begin{array}{c}\text { (Eng. Greater galangal, thai } \\
\text { galangal, blue ginger, thai ginger) }\end{array}$ & {$[180,181]$} & {$[24]$} \\
\hline 135 & & Zingiber officinale & Roscoe & (Eng. Ginger) & [182] & [24] \\
\hline 136 & \multirow{2}{*}{$\begin{array}{l}\text { Zygophyllaceae (Caltrop, } \\
\text { bean-caper, creosote-bush family) }\end{array}$} & Peganum harmala & $\mathrm{L}$. & $\begin{array}{l}\text { (Eng. African rue, Syrian rue, wild } \\
\text { rue, harmal shrub, harmel, isband, } \\
\text { ozallalk, steppenraute) }\end{array}$ & [183] & {$[24]$} \\
\hline 137 & & Tribulus parvispinus & Presl & $\begin{array}{l}\text { (Syn. Tribulus terrestris) (Eng. } \\
\text { Puncture vine, Land caltrops, } \\
\text { puncture vine) (Arb. Shershir, kuteb } \\
\text { "qatb", hisek, badl, shuraysah, } \\
\text { shiqshiq, dreiss) }\end{array}$ & [184] & {$[15,21]$} \\
\hline
\end{tabular}


According to Raut and Karuppayil [185] there are around 2000 identified EO-bearing plants globally. Therefore, it is of high value that a country (with estimated $83 \mathrm{~km}^{2}$ land area and with limited freshwater resources) includes 137 EO-bearing plants. It is worth mentioning that although some of the UAE indigenous and naturalized plants have rich traditional therapeutic applications and belong to important medicinal families, there are no data yet available related to the potential of their EOs. Therefore, it is expected that many of the medicinal and aromatic plants that are available locally are not investigated yet, and the true estimation of the Emirati EO-bearing plants could be underestimated. Examples of these species include, Amaranthus graecizans and Amaranthus viridis from the Amaranthaceae family, which were used in the past by the Bedouin people of the UAE to treat scorpion stings, snake bites and itchy skin rashes as reported by Sakkir et al. [28].

An overview of all EO-bearing plant families growing in the United Arab Emirates, their species number, natural habitats, potential plant parts and ecological status are illustrated in Figures 1-4. Based on our results, the families that include the highest number of EO-bearing species are Asteraceae, (22 plants, 16.2\%), Fabaceae (11 plants, $8.1 \%$ ), Lamiaceae (11 plants, $8.1 \%$ ), Brassicaceae (9 plants, 6.6\%), Apiaceae (7 plants, $5.1 \%$ ) and Poaceae (7 plants, 5.1\%), respectively, as shown in Figure 1.

Generally, the most important habitats are the plantations, farmlands and irrigated lands, which host $50 \%$ of the Emirati EO-bearing plants. Meanwhile, the most important natural habitats are mountains and rocky terrain, wadis, sandy dunes and coastal saline lines, hosting $36.3,24.4,15.5$ and $14.8 \%$ of the total EO-bearing plants growing in the United Arab Emirates, respectively (Figure 2).

Since plantations and farmlands are hosting $50 \%$ of the Emirati EO-bearing plants (which could be due to their ornamental or food production value, or just available naturally as weeds due to the accessibility of water), there should be educational campaigns to educate landlords about extra potentials and economic benefits related to EOs of their available indigenous plants. In addition, with the sharp population growth and the current expansion in the industrial and urbanization activities, strong efforts should be invested to conserve the natural habitats of the EO-bearing plants (e.g., mountains, wadis), and take the same into consideration in strategic planning and management.

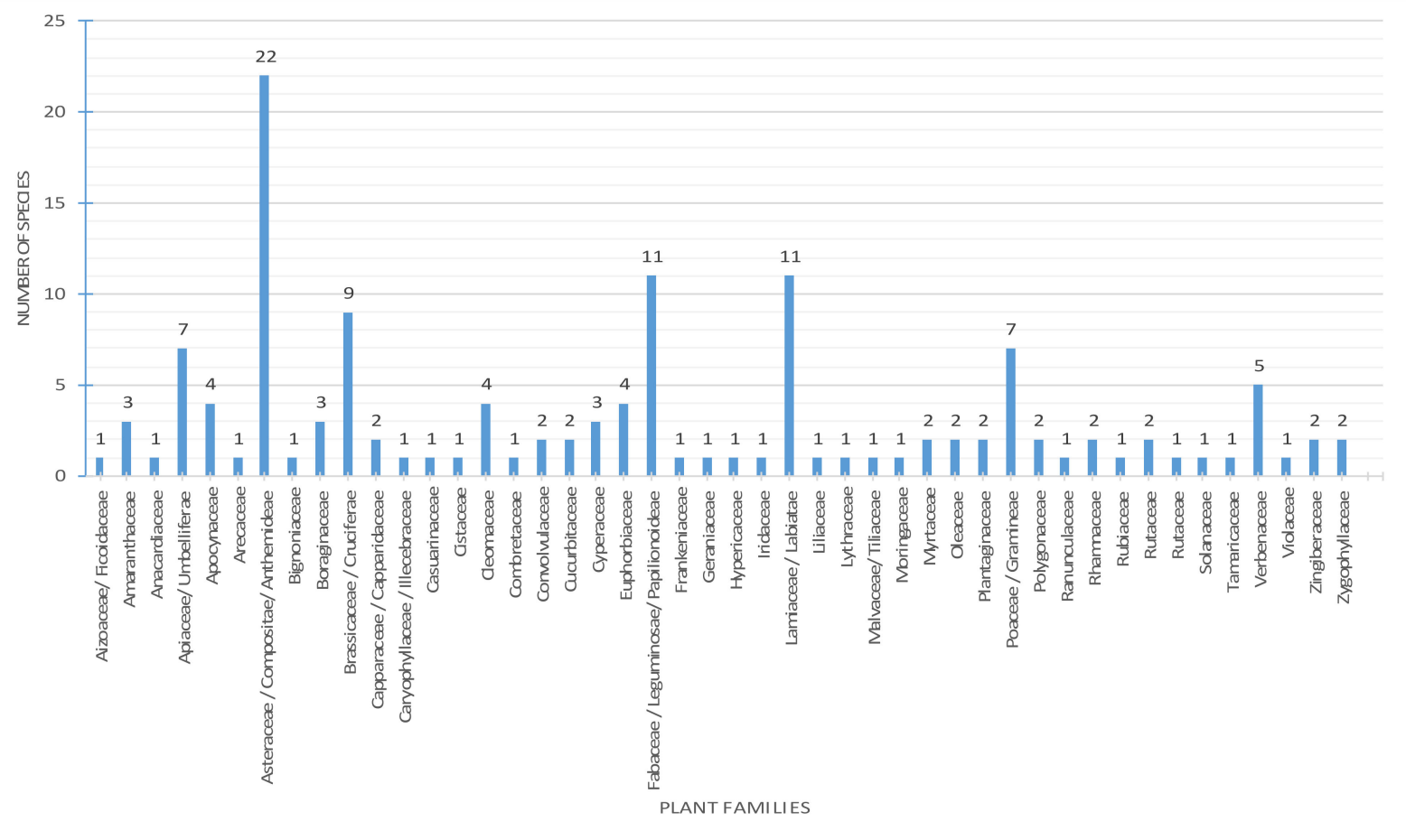

Figure 1. Families of EO-bearing plant species in the UAE. 


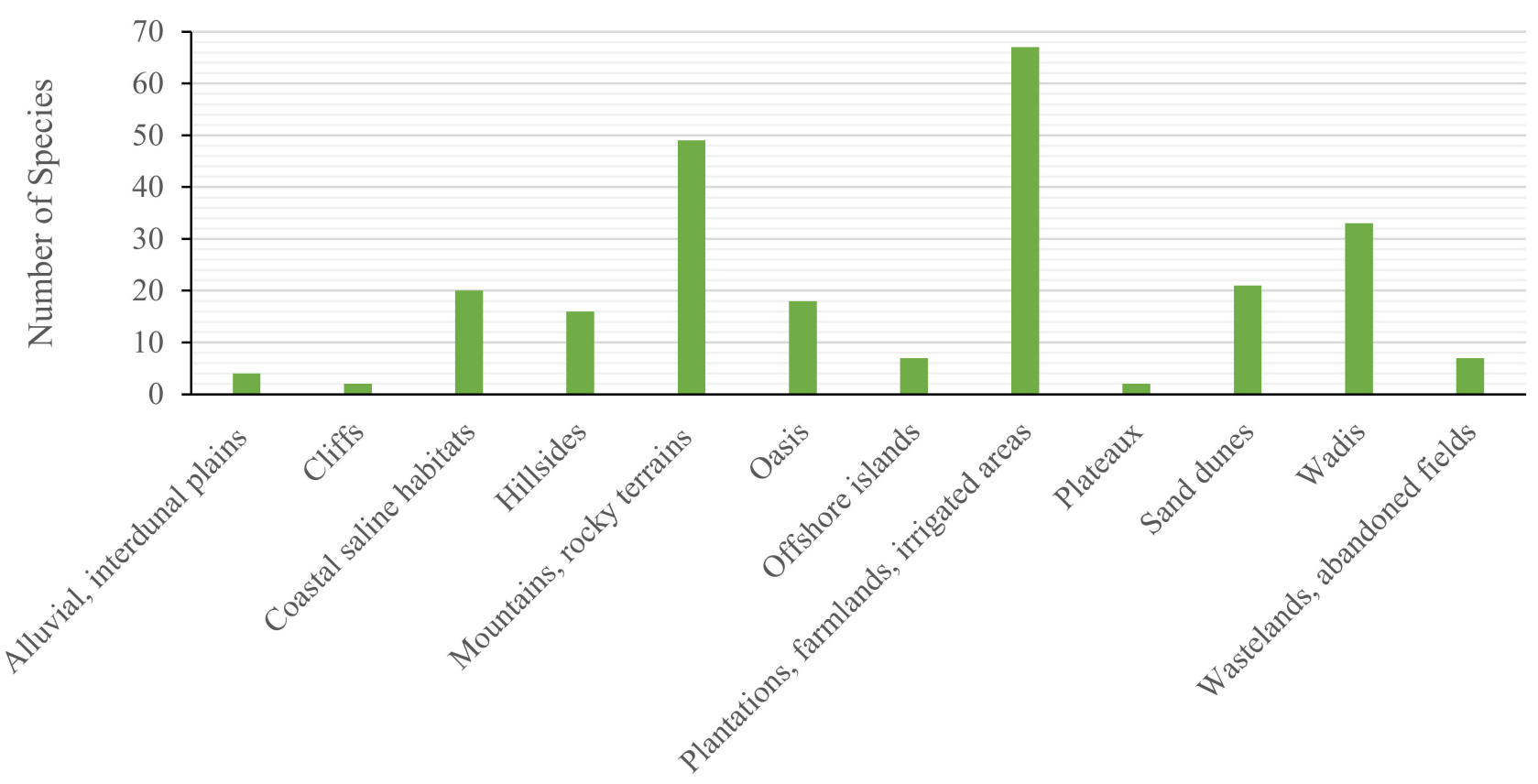

Habitats

Figure 2. Habitats of EO-bearing plants in the UAE.

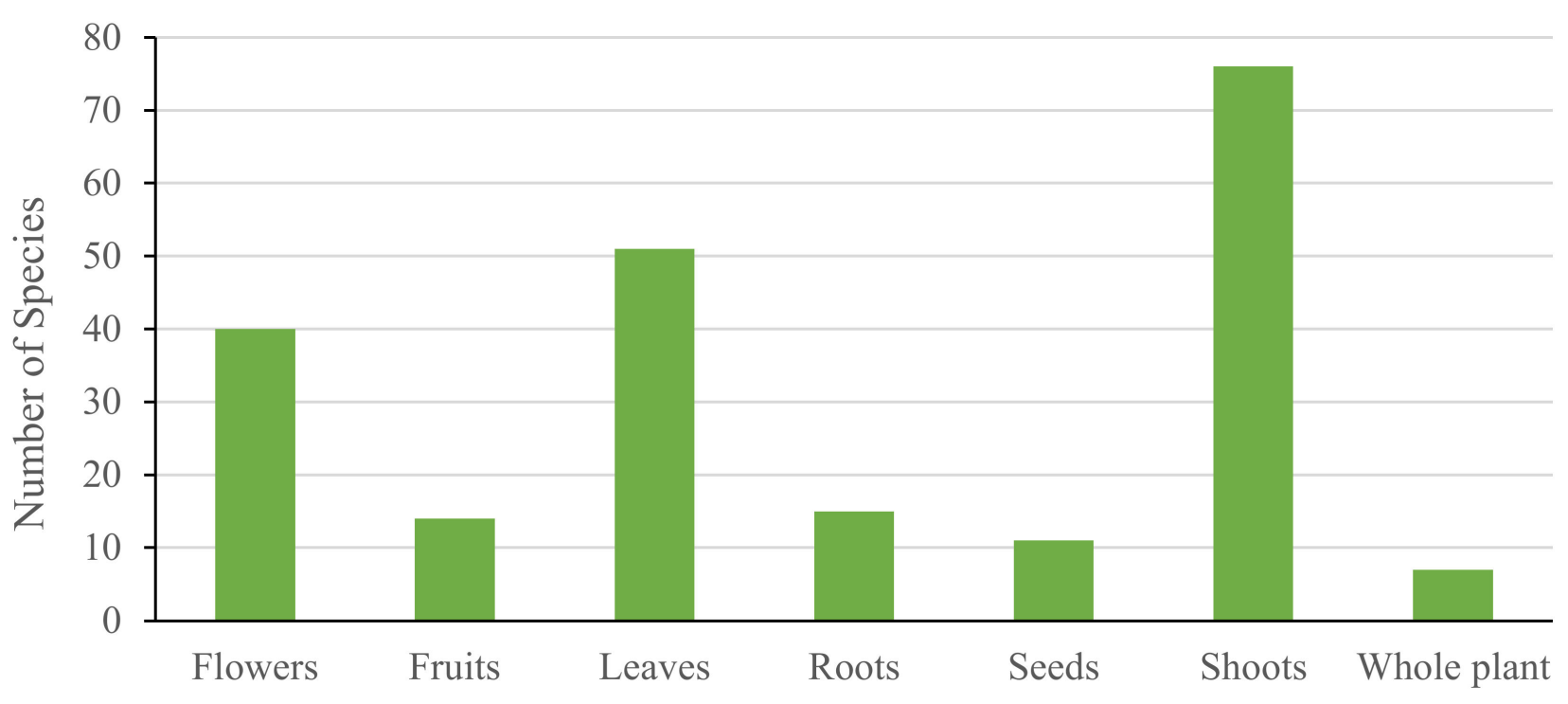

Potential Plant Parts

Figure 3. Major plant parts for EO production in the UAE.

Based on our results, shoots (particularly leaves and flowers) are the most important parts that have potential for EOs, in which, 56.3, 37.8 and 29.6\% of the Emirati-EO-bearing plants have the potential to extract EOs from their shoots, leaves and flowers, respectively (Figure 3).

Our results show that $82 \%$ of the status of the Emirati EO-bearing plants are reported as least concerned plants (low risks of becoming endangered), as shown in Figure 4. However, since recent references that report the status of indigenous plants are limited, and taking into consideration that status of $10 \%$ of the plants are not yet evaluated, their real status could be underestimated, especially with the current population growth and urbanization activities. 


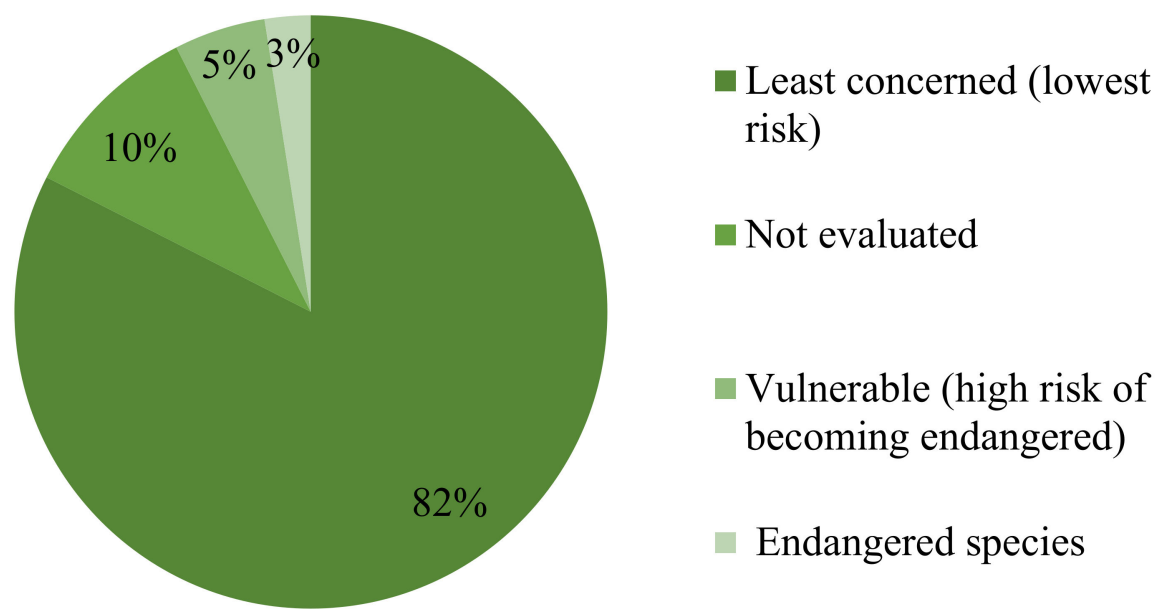

Figure 4. Status of EO-bearing plants in the UAE.

\subsection{A Detailed Overview}

A detailed view on the results of the top three richest families (based on the number of EO-bearing species) is divided into three table groups (Tables 2-10). The first group represents the general botanical information related to the plant species, including form, life form, life cycle, economic value and folk medicine/applications, internationally and locally (Tables 2, 5 and 8). The second group illustrates the data related to the plants' natural habitats in the UAE, including important locations, soil, habitats, flowering period and wildlife status (Tables 3,6 and 9). The third group shows detailed knowledge related to plants' EOs, including potential plant parts, yields, extraction methods, main chemical groups/constituents and biological activities (Tables 4, 7 and 10). 
Table 2. The UAE EO-bearing species of Asteraceae/Compositae/Anthemideae Family.

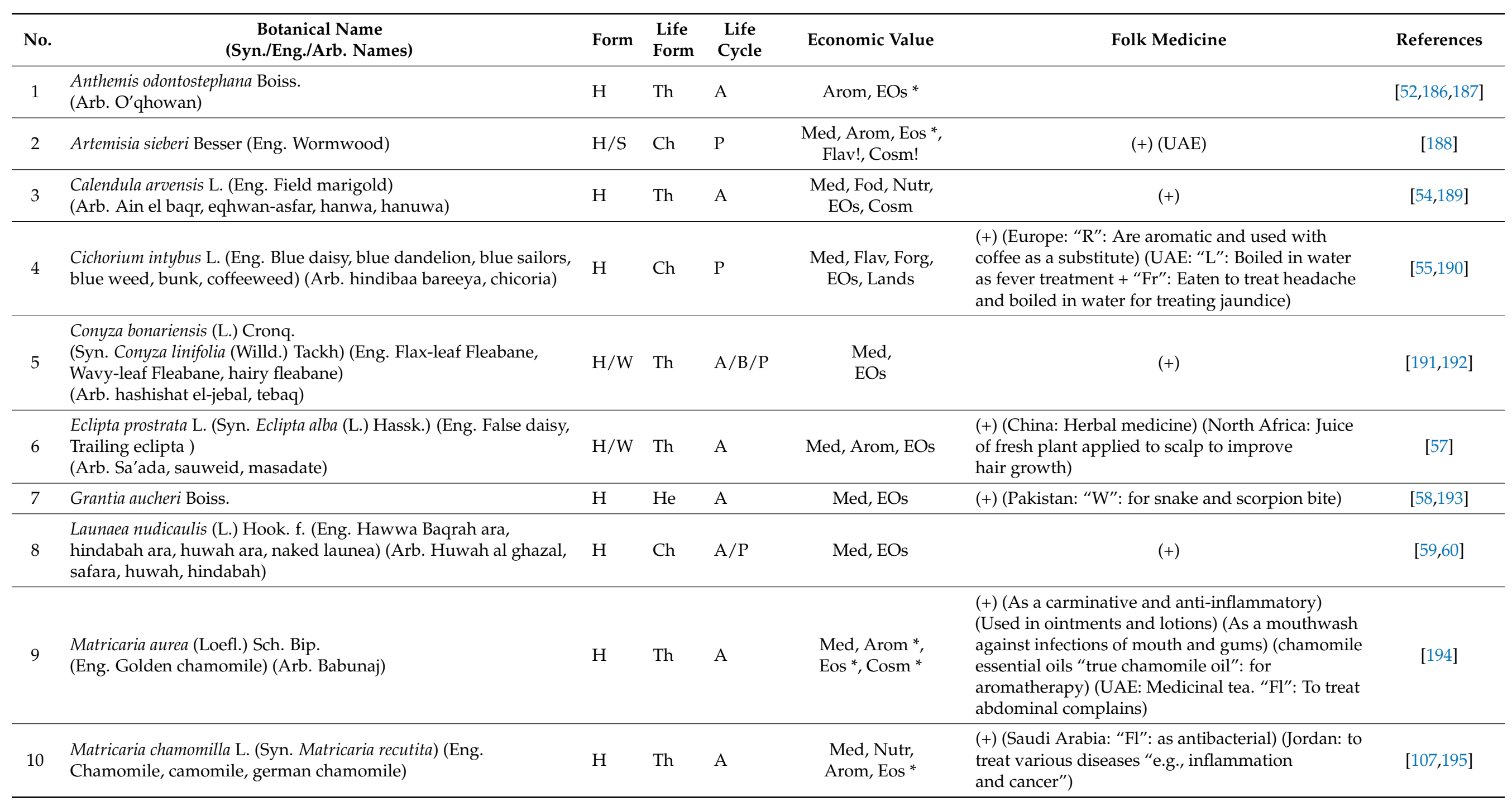


Table 2. Cont.

\begin{tabular}{|c|c|c|c|c|c|c|c|}
\hline No. & $\begin{array}{c}\text { Botanical Name } \\
\text { (Syn./Eng./Arb. Names) }\end{array}$ & Form & $\begin{array}{l}\text { Life } \\
\text { Form }\end{array}$ & $\begin{array}{l}\text { Life } \\
\text { Cycle }\end{array}$ & Economic Value & Folk Medicine & References \\
\hline 11 & $\begin{array}{l}\text { Pluchea arabica (Boiss.) Qaiser and Lack } \\
\text { (Eng. Pluchea) (Arb. godot) }\end{array}$ & $\mathrm{H}$ & $\mathrm{Ch}$ & $\mathrm{P}$ & $\begin{array}{l}\text { Med, Arom, } \\
\text { Eos *, Cosm }\end{array}$ & $\begin{array}{l}\text { (+) (UAE: To treat skin and as doedorant) (“W": } \\
\text { Boiled to treat skin ailments + "L": Extract used as ear } \\
\text { drops + "L": Fresh "L" rubbed on body as deodorant) }\end{array}$ & {$[64,66]$} \\
\hline 12 & $\begin{array}{l}\text { Pluchea dioscoridis (L.) DC. (Syn. Conyza dioscoridis (L.) Desf., } \\
\text { Baccharis dioscoridis L.) } \\
\text { (Eng. Ploughmans spikenard, marsh fleabane) } \\
\text { (Arb. Sahikee, barnof) }\end{array}$ & $\mathrm{S} / \mathrm{T}$ & $\mathrm{Ch}$ & $\mathrm{P}$ & Med *, Arom, EOs & (+) (Many Important Applications) (UAE) & {$[65,66]$} \\
\hline 13 & $\begin{array}{l}\text { Pluchea ovalis (pers.) DC. } \\
\text { (Eng. Woolly camphor-weed) }\end{array}$ & $\mathrm{S} / \mathrm{T}$ & $\mathrm{Ph}$ & $\mathrm{A} / \mathrm{P}$ & Med *, Arom, EOs & $(+)(\mathrm{UAE})$ & {$[66]$} \\
\hline 14 & $\begin{array}{l}\text { Pseudognaphalium luteo-album (L.) H. and B. (Syn. Gnaphalium } \\
\text { luteo-album L.) (Eng. Cudweed) } \\
\text { (Arb. sabount el'afrit) }\end{array}$ & $\mathrm{F} / \mathrm{H}$ & Th & A & EOs & $(+)$ & {$[67]$} \\
\hline 15 & $\begin{array}{l}\text { Pulicaria arabica (L.) Cass. (Syn. Inula arabica L./Pulicaria elata } \\
\text { Boiss./Pulicaria laniceps Bornm.) (Arb. Iqat, abu ‘ain safra) }\end{array}$ & $\mathrm{H}$ & $\mathrm{He}$ & $\mathrm{A} / \mathrm{P}$ & EOs & . & [7] \\
\hline 16 & $\begin{array}{l}\text { Pulicaria glutinosa Jaub. and Spach (Arb. Thal, fal, shajarat fal, } \\
\text { muhayda, mithidi, shajarat al-mithidi, shneena, zayyan) }\end{array}$ & $\mathrm{S}$ & $\mathrm{Ch}$ & $\mathrm{P}$ & Arom *, EOs, Oth * & & [7] \\
\hline 17 & Pulicaria inuloides (Poir.) DC. & $S$ & $\mathrm{Ch}$ & $\mathrm{P}$ & $\begin{array}{l}\text { Med, Fod, Forg, } \\
\text { Arom, EOs, Fuel }\end{array}$ & $(+)$ & [69-71] \\
\hline 18 & $\begin{array}{l}\text { Pulicaria undulata (L.) C.A. Meyer (Syn. Pulicaria crispa (Forssk.) } \\
\text { Benth.) (Eng. Crisp-leaved fleabane) (Arb. Gathgeth, } \\
\text { jithjath, 'urayfijan) }\end{array}$ & $\mathrm{H} / \mathrm{S}$ & $\mathrm{Ch}$ & $\mathrm{A} / \mathrm{P}$ & $\begin{array}{l}\text { Med *, Fod, Forg, } \\
\text { Arom, Eos *, Fuel }\end{array}$ & $\begin{array}{l}(+) \text { (Dropsy, swelling, edema, gout, febrifuges, } \\
\text { painkillers) (Egypt: To treat measles and } \\
\text { repel insects) }\end{array}$ & [196] \\
\hline 19 & Rhanterium epapposum Oliv. (Eng. Rhanterium) (Arb. Arfaj) & $\mathrm{S}$ & $\mathrm{Ch}$ & $\mathrm{p}$ & $\begin{array}{l}\text { Forg *, Flav, } \\
\text { EOs, Fuel }\end{array}$ & & [197] \\
\hline 20 & $\begin{array}{l}\text { Senecio glaucus L. ssp. coronopifolius (Maire) Al. (Syn. Senecio } \\
\text { desfontanei Druce) (Eng. Maire alexander, buck's horn groundsel) } \\
\text { (Arb. Qorreis, murair, zamlooq, shakhees, rejel al ghurab) }\end{array}$ & $\mathrm{H}$ & Th & A & Arom, Eos * & & [198] \\
\hline 21 & $\begin{array}{l}\text { Seriphidium herba-alba (Asso) Sojak (Syn. Artemisia herba-alba } \\
\text { Asso/Artemisia inculta Del) (Eng. Wormwood, white } \\
\text { wormwood) (Arb. Ata, ghata, shih) }\end{array}$ & $\mathrm{S}$ & $\mathrm{Ph}$ & $\mathrm{P}$ & Med, Eos *, FPre! & $\begin{array}{l}\text { (+) (Tunisia) (Inhaling smoke thought to be beneficial } \\
\text { for both man and animals) ("Sh": Young "Sh" eaten } \\
\text { by mountain travellers) (Many applications) (UAE: } \\
\text { "L": Crushed as a worm treatment and to combat } \\
\text { fevers + Many applications) }\end{array}$ & [76] \\
\hline
\end{tabular}


Table 2. Cont.

\begin{tabular}{|c|c|c|c|c|c|c|c|}
\hline No. & $\begin{array}{l}\text { Botanical Name } \\
\text { (Syn./Eng./Arb. Names) }\end{array}$ & Form & $\begin{array}{l}\text { Life } \\
\text { Form }\end{array}$ & $\begin{array}{l}\text { Life } \\
\text { Cycle }\end{array}$ & Economic Value & Folk Medicine & References \\
\hline 22 & $\begin{array}{l}\text { Sphagneticola trilobata (Syn. Wedelia paludosa DC.) (Eng. Singapore } \\
\text { daisy, creeping-oxeye, trailing daisy, wedelia) }\end{array}$ & $\mathrm{H}$ & $\mathrm{Ch}$ & $\mathrm{P}$ & Med, EOs, Lands * & $(+)($ Brazil $)$ & {$[75,77]$} \\
\hline
\end{tabular}

Table 3. The UAE EO-bearing species of Fabaceae/Leguminosae/Papilionoideae Family.

\begin{tabular}{|c|c|c|c|c|c|c|c|}
\hline No. & $\begin{array}{c}\text { Botanical Name } \\
\text { (Syn./Eng./Arb. Names) }\end{array}$ & Form & $\begin{array}{l}\text { Life } \\
\text { Form }\end{array}$ & $\begin{array}{l}\text { Life } \\
\text { Cycle }\end{array}$ & Economic Value & Folk Medicine & References \\
\hline 1 & $\begin{array}{l}\text { Alhagi maurorum Medik. (Syn. Alhagi graecorum Boiss.) (Eng. } \\
\text { Camelthorn, camelthorn-bush, caspian manna, persian } \\
\text { mannaplant) (Arb. Shwaika, agool, heidj) }\end{array}$ & $\mathrm{H} / \mathrm{S}$ & $\mathrm{He} / \mathrm{Na}$ & $\mathrm{P}$ & $\begin{array}{l}\text { Med, } \\
\text { EOs, Biof }\end{array}$ & $\begin{array}{l}(+) \text { (Infusion of plant or plant juice used to treat } \\
\text { worm infestations, cataract, jaundicem migraine, } \\
\text { arthritis, constipation) (" } R \text { ": Green " } R \text { " boiled and } \\
\text { taken as tea with lime, as an aphrodisiac and to } \\
\text { treat kidney disease) (UAE) }\end{array}$ & [113] \\
\hline 2 & $\begin{array}{l}\text { Lotus halophilus Boiss. and Spruner (Eng. Greater bird's foot trefoi) } \\
\text { (Arb. Horbeith “hurbuth", garn al ghazal, 'asheb al ghanem) }\end{array}$ & $\mathrm{V} ! / \mathrm{H}$ & Th & $\mathrm{A} / \mathrm{P}$ & $\begin{array}{l}\text { Med, Fod, Forg, } \\
\text { EOs, Lands }\end{array}$ & $(+)$ (Qatar: as tonic and sedative) & {$[79,89]$} \\
\hline 3 & $\begin{array}{l}\text { Medicago polymorpha L. (Eng. California burclover, toothed bur } \\
\text { clover, toothed medick, burr medic) }\end{array}$ & $\mathrm{F} / \mathrm{W}$ & Th & A & $\begin{array}{l}\text { Med *, Fod, Forg, } \\
\text { EOs, Eco, Lands }\end{array}$ & $\begin{array}{l}\text { (+) (India: for medicinal purposes for skin plagues } \\
\text { and dysentery) (Bolivia: for medicinal purposes } \\
\text { since } 16 \text { century) (Italy: for treating rheumatic } \\
\text { pains, wounds and still used until today) }\end{array}$ & [115] \\
\hline 4 & Medicago sativa L. (Eng. Alfalfa, lucerne) & $\mathrm{H}$ & $\mathrm{He}$ & $\mathrm{P}$ & $\begin{array}{l}\text { Med *, Forg *, } \\
\text { EOs, Eco }\end{array}$ & $\begin{array}{l}\text { (+) (Great therapeutic benefits) (Used for boosting } \\
\text { energy levels) }\end{array}$ & [116] \\
\hline 5 & $\begin{array}{l}\text { Rhynchosia minima (L.) DC. (Eng. least snout-bean, } \\
\text { burn-mouth-vine and jumby bean) (Arb. Baql) }\end{array}$ & $\mathrm{V} / \mathrm{H}$ & $\mathrm{Ch}$ & $\mathrm{P}$ & Med, EOs & (+) (Saudi Arabia: Used as abortive) (UAE) & {$[116,117]$} \\
\hline 7 & $\begin{array}{l}\text { Trigonella hamosa L. (Eng. Branched fenugreek, egyptian } \\
\text { fenugreek) (Arb. Nafal, qutifa, qirqas, darjal, eshb al-malik, qurt) }\end{array}$ & $\mathrm{H}$ & Th & $\mathrm{A}$ & Med, Forg, Flav, EOs & $(+)$ & [79] \\
\hline 8 & Ononis sicula Guss. & $\mathrm{H}$ & Th & A & EOs & . & [119] \\
\hline
\end{tabular}


Table 3. Cont.

\begin{tabular}{|c|c|c|c|c|c|c|c|}
\hline No. & $\begin{array}{c}\text { Botanical Name } \\
\text { (Syn./Eng./Arb. Names) }\end{array}$ & Form & $\begin{array}{l}\text { Life } \\
\text { Form }\end{array}$ & $\begin{array}{l}\text { Life } \\
\text { Cycle }\end{array}$ & Economic Value & Folk Medicine & References \\
\hline 9 & $\begin{array}{l}\text { Acacia nilotica (L.) Delile (Syn. Acacia Arabica (Lam.) Willd.) (Eng. } \\
\text { Gum arabic tree, babul/kikar, egyptian thorn, sant tree, al-sant, } \\
\text { prickly acacia) } \\
\text { (Arb. Sunt garath "kurut", babul, tulh. Fruit: karat) }\end{array}$ & $\mathrm{T}$ & $\mathrm{Ph}$ & $\mathrm{P}$ & Med *, EOs, Lands & $\begin{array}{l}\text { (+) (Pearl drivers used to apply an infusion of } \\
\text { fruits to skin after dives) ("L": Poultice of "L" used } \\
\text { to treat joint pains) (Resin mixed with egg-white } \\
\text { applied to eyes to treat cararacts) ("L": Eaten to } \\
\text { treat diarrhoea) ("Se": Soaked in water or milk } \\
\text { drunk to treat diabetes) ("Pd": Smoke from } \\
\text { burning "Pds" inhaled for colds) (UAE: Applied to } \\
\text { soothe burns. "L": are pounded into a paste and } \\
\text { used a poultice on boils and swellings or applied } \\
\text { around boils to draw out the pus) }\end{array}$ & [120] \\
\hline 10 & $\begin{array}{l}\text { Acacia tortilis (Forssk.) Hayne (Eng. Umbrella thorn) (Arb. Samr } \\
\text { "samur", salam) }\end{array}$ & $\mathrm{S} / \mathrm{T}$ & $\mathrm{Ph}$ & $\mathrm{P}$ & Med, Forg, EOs & $\begin{array}{l}(+) \text { (Mostly yields resin, used as a gum to heal } \\
\text { wounds) }\end{array}$ & [122] \\
\hline 11 & $\begin{array}{l}\text { Prosopis farcta (Banks and Sol.) Mac. } \\
\text { (Eng. Dwarf mesquite, syrian mesquite) } \\
\text { (Arb. Yanbut, agoul, awsaj) }\end{array}$ & $\mathrm{S}$ & $\mathrm{Ch}$ & $\mathrm{P}$ & EOs & . & {$[123,128]$} \\
\hline
\end{tabular}

Table 4. The UAE EO-bearing species of Lamiaceae/Labiatae.

\begin{tabular}{|c|c|c|c|c|c|c|c|}
\hline No. & $\begin{array}{c}\text { Botanical Name } \\
\text { (Syn./Eng./Arb. Names) }\end{array}$ & Form & $\begin{array}{l}\text { Life } \\
\text { Form }\end{array}$ & $\begin{array}{l}\text { Life } \\
\text { Cycle }\end{array}$ & Economic Value & Folk Medicine & References \\
\hline 1 & $\begin{array}{l}\text { Lallemantia royleana (Benth.) Benth. } \\
\text { (Eng. Bian bing cao) }\end{array}$ & $\mathrm{H}$ & Th & A & Med *, Eos* & $(+)$ & [128] \\
\hline 2 & Mentha spicata (Eng. Spearmint, spear mint) & $\mathrm{H}$ & $\mathrm{He}$ & $\mathrm{P}$ & $\begin{array}{l}\text { Med, Fod, Flav, } \\
\text { Arom *, Eos * }\end{array}$ & $(+)(\mathrm{UAE})$ & [199] \\
\hline 3 & $\begin{array}{l}\text { Ocimum forsskaolii Benth. } \\
\text { (Syn. Ocimum forskolei Benth.) (Eng. Rehan, sawma) } \\
\text { (Arb. Basil) }\end{array}$ & $\mathrm{H}$ & Th & $\mathrm{A} / \mathrm{P}$ & $\begin{array}{l}\text { Med *, Arom, EOs, } \\
\text { Insec, Lands, Oth }\end{array}$ & $\begin{array}{l}\text { (+) (Oman: "L": as deodorant + "L": Fragnance } \\
\text { eases headaches and dizziness + "L": Crushed and } \\
\text { placed in nose to treat colds and in ears to treat } \\
\text { earaches + "L": Juice from young "L" as eye drops } \\
\text { or to soothe insect bites) (UAE: "L": to treat } \\
\text { vomiting, against itching) }\end{array}$ & {$[69,131]$} \\
\hline
\end{tabular}


Table 4. Cont.

\begin{tabular}{|c|c|c|c|c|c|c|c|}
\hline No. & $\begin{array}{c}\text { Botanical Name } \\
\text { (Syn./Eng./Arb. Names) }\end{array}$ & Form & $\begin{array}{l}\text { Life } \\
\text { Form }\end{array}$ & $\begin{array}{l}\text { Life } \\
\text { Cycle }\end{array}$ & Economic Value & Folk Medicine & References \\
\hline 4 & $\begin{array}{l}\text { Salvia aegyptiaca L. (Eng. Egyptian sage) (Arb. Ra'al, na'aim, } \\
\text { ghbeisha, shajarat al ghazal, khizam) }\end{array}$ & $\mathrm{H}$ & $\mathrm{Ch} / \mathrm{Th}$ & $\mathrm{A} / \mathrm{P}$ & $\operatorname{Med}{ }^{*}, \operatorname{Eos}^{*}$ & $\begin{array}{l}(+) \text { (To treat diarrhoea, gonorrhoea and } \\
\text { haemorrhoids) (As demulcent, antispasmodic, } \\
\text { cicatrizant, antiseptic and stomachic) (Its non-polar } \\
\text { extracts have been tested as antimicrobial) (Nutlets } \\
\text { are used in a drink to treat diarrhoea and piles) } \\
\text { (UAE) }\end{array}$ & [2] \\
\hline 5 & $\begin{array}{l}\text { Salvia macilenta Boiss. (Eng. Khizama) } \\
\text { (Arb. Khmayzah lethnay, bithman) }\end{array}$ & $\mathrm{H}$ & $\mathrm{Ch}$ & $\mathrm{P}$ & Med, Eos* & $(+)$ & [3] \\
\hline 6 & Salvia macrosiphon Boiss. (Arb. Shajarat Al Ghazal) & $\mathrm{H}$ & $\mathrm{He}$ & $\mathrm{P}$ & Med, Eos* & $(+)$ & {$[140,141]$} \\
\hline 7 & Salvia mirzayanii Rech.f. and Esfandiari & $\mathrm{H}$ & $\mathrm{Ch}$ & $\mathrm{P}$ & EOs & . & [200] \\
\hline 8 & Salvia spinosa L. (Arb. Shajarat al-ghazal) & $\mathrm{H}$ & $\mathrm{He}$ & $\mathrm{P}$ & Eos* & . & [136] \\
\hline 9 & Teucrium polium L. (Eng. Felty germander) & $\mathrm{H} / \mathrm{S}$ & Th & $\mathrm{P}$ & Med *, Arom, EOs & $\begin{array}{l}(+) \text { (to treat liver diseases, antispasmodic, } \\
\text { antidiabetic and lowering blood lipid) (Many } \\
\text { medicinal uses: to treat malaria, insect bites and } \\
\text { abscesses) (UAE: "L" and "St") }\end{array}$ & [137] \\
\hline 11 & Zataria multiflora Boiss. (Eng. Za'atar, shirazi thyme) & $\mathrm{H}$ & $\mathrm{Ch}$ & $\mathrm{P}$ & $\begin{array}{l}\text { Med, Flav, } \\
\text { Arom, Eos * }\end{array}$ & $(+)$ (UAE: to treat cold, indigestion, toothache) & [141] \\
\hline
\end{tabular}

Table 5. Location of the UAE EO-bearing plants of Asteraceae/Compositae/Anthemideae.

\begin{tabular}{|c|c|c|c|c|c|c|c|c|}
\hline No. & Botanical Name & Emirates & $\begin{array}{l}\text { Important } \\
\text { Locations }\end{array}$ & Soil & Habitats & Flowering & $\begin{array}{l}\text { Wildlife Status } \\
\text { (Past) vs. } \\
\text { (Present) }\end{array}$ & References \\
\hline 1 & Anthemis odontostephana Boiss. & $(\mathrm{RAK}, \mathrm{F})$ & (RA) & (Sil, Roc) & (Mou) & Feb. to Apr. & $(\mathrm{NC})(\mathrm{CO})$ & {$[15,21]$} \\
\hline 2 & Artemisia sieberi Besser & & . & & . & . & $(\mathrm{CO})$ & [28] \\
\hline
\end{tabular}


Table 5. Cont.

\begin{tabular}{|c|c|c|c|c|c|c|c|c|}
\hline No. & Botanical Name & Emirates & $\begin{array}{l}\text { Important } \\
\text { Locations }\end{array}$ & Soil & Habitats & Flowering & $\begin{array}{l}\text { Wildlife Status } \\
\text { (Past) vs. } \\
\text { (Present) }\end{array}$ & References \\
\hline 3 & Calendula arvensis $\mathrm{L}$. & $(\mathrm{RAK}, \mathrm{F}, \mathrm{S})$ & (HM, RA) & (Sil, Roc) & (FF, Mou) & $\begin{array}{l}\text { Jan. to Mar. June } \\
\text { to Nov. }\end{array}$ & $(\mathrm{CO})(\mathrm{NC}, \mathrm{CO})$ & {$[15,21]$} \\
\hline 4 & Cichorium intybus L. & (RAK) & . & (San) & $(\mathrm{FF})$ & Feb. to Apr. & $(\mathrm{CO}, \mathrm{RA})(\mathrm{RA})$ & {$[15,21,28]$} \\
\hline 5 & Conyza bonariensis (L.) Cronq. & $(\mathrm{AD})$ & (SL) & . & (Oas, Gar, Plat) & Jan. to May. & $(\mathrm{CO})$ & {$[21,22]$} \\
\hline 6 & Eclipta prostrata L. & $(\mathrm{F})$ & (SL) & . & (Plat) & Dec. to Apr. & $(\mathrm{NC})(\mathrm{NC})$ & {$[15,21]$} \\
\hline 7 & Grantia aucheri Boiss. & $(\mathrm{AD})$ & (Ain) & . & (Rod, Wad) & Jan. to Apr. & . & [27] \\
\hline 8 & Launaea nudicaulis (L.) Hook. f. & $(\mathrm{AD}, \mathrm{Du})$ & (SL) & (San) & (Oas, Plat) & Feb. to Apr. & $(\mathrm{CO})(\mathrm{NC})$ & {$[15,21,22]$} \\
\hline 9 & Matricaria aurea (Loefl.) Sch. Bip. & $(\mathrm{RAK}, \mathrm{F})$ & (RA) & (Sil, Roc) & (PX, Mou) & Feb. to Apr. & $(\mathrm{CO})(\mathrm{CO})$ & {$[21,28]$} \\
\hline 10 & Matricaria chamomilla $\mathrm{L}$. & . & . & . & (Rod!, AF!) & . & . & [63] \\
\hline 11 & $\begin{array}{c}\text { Pluchea arabica (Boiss.) Qaiser and } \\
\text { Lack }\end{array}$ & (RAK) & . & (Roc) & (Wad, Plat, Wat) & Feb. to Apr. & (NE) (RA) & {$[28]$} \\
\hline 12 & Pluchea dioscoridis (L.) DC. & . & $(\mathrm{WC})$ & (San, Sal) & $\begin{array}{l}\text { (Cos, Oas, Gar, } \\
\text { Urb, AF) }\end{array}$ & Through the year. & $(\mathrm{CO})(\mathrm{CO})$ & {$[15,21,22]$} \\
\hline 13 & Pluchea ovalis (pers.) DC. & $(\mathrm{Du})$ & . & . & . & . & $(\mathrm{NC})$ & {$[15,21]$} \\
\hline 14 & $\begin{array}{l}\text { Pseudognaphalium luteo-album (L.) H. } \\
\text { and B. }\end{array}$ & $(\mathrm{AD})$ & (Ain) & . & (Plat) & Feb. to May. & $(\mathrm{CO})$ & {$[21,22]$} \\
\hline 15 & Pulicaria arabica (L.) Cass. & $(\mathrm{S}, \mathrm{F}, \mathrm{RAK})$ & $(\mathrm{HM})$ & . & (Wad, Wat, Plat) & Feb. to Apr. & $\begin{array}{l}(\mathrm{NC}, \mathrm{CO})(\mathrm{NC} \\
\mathrm{CO})\end{array}$ & {$[21]$} \\
\hline 16 & Pulicaria glutinosa Jaub. and Spach & (F, RAK, S, AD) & $(\mathrm{HM})$ & (Roc) & (Plat, Mou) & Feb. to Jun. & $(\mathrm{CO})(\mathrm{CO})$ & {$[15,21,22]$} \\
\hline 17 & Pulicaria inuloides (Poir.) DC. & . & . & . & . & . & . & [21] \\
\hline 18 & Pulicaria undulata (L.) C.A. Meyer & $(\mathrm{RAK}, \mathrm{AD})$ & $(\mathrm{SL})$ & (San, Sil) & $(\mathrm{Apl}, \mathrm{AF})$ & $\begin{array}{l}\text { Apr. to Jul. Mar. to } \\
\text { Aug.! Mar. to } \\
\text { June! }\end{array}$ & $(\mathrm{FC})(\mathrm{FC})$ & {$[15,21,22]$} \\
\hline 19 & Rhanterium epapposum Oliv. & $(\mathrm{AD})$ & $\begin{array}{l}\text { (Ain, CC, EE, } \\
\text { NE) }\end{array}$ & (San, Roc) & $\begin{array}{l}\text { (Dun, Plat, Apl, } \\
\text { Hil) }\end{array}$ & Jan. to May. & $(\mathrm{CO})$ & {$[15,21,22]$} \\
\hline 20 & $\begin{array}{l}\text { Senecio glaucus L. ssp. } \\
\text { coronopifolius (Maire) Al. }\end{array}$ & (RAK, UAQ, AD) & $(\mathrm{CN})$ & (San, Sal) & $(\mathrm{Cos}, \mathrm{FF})$ & Feb. to Apr. & $(\mathrm{CO})(\mathrm{CO})$ & {$[15,21,22]$} \\
\hline
\end{tabular}


Table 5. Cont

\begin{tabular}{|c|c|c|c|c|c|c|c|c|}
\hline No. & Botanical Name & Emirates & $\begin{array}{l}\text { Important } \\
\text { Locations }\end{array}$ & Soil & Habitats & Flowering & $\begin{array}{l}\text { Wildlife Status } \\
\text { (Past) vs. } \\
\text { (Present) }\end{array}$ & References \\
\hline 21 & Seriphidium herba-alba (Asso) Sojak & $(\mathrm{RAK}, \mathrm{F})$ & (RA) & (Roc) & (PX, Mou) & Feb. to Apr. & $(\mathrm{NC})(\mathrm{CO})$ & [21] \\
\hline 22 & Sphagneticola trilobata & . & . & . & & $\begin{array}{l}\text { Through the year. } \\
\text { Spring to Autumn! }\end{array}$ & & [15] \\
\hline
\end{tabular}

Table 6. Location of the UAE EO-bearing plants of Fabaceae/Leguminosae/Papilionoideae.

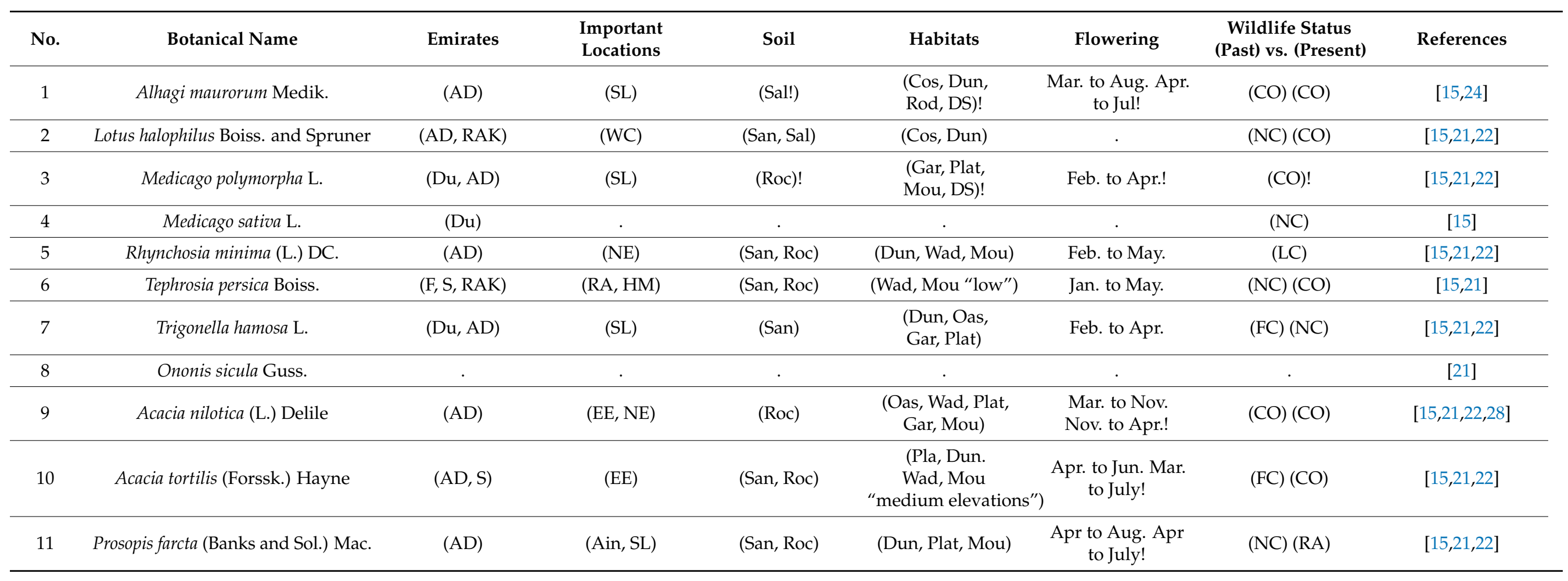


Table 7. Location of the UAE EO-bearing plants of Lamiaceae/Labiatae.

\begin{tabular}{|c|c|c|c|c|c|c|c|c|}
\hline No. & Botanical Name & Emirates & $\begin{array}{l}\text { Important } \\
\text { Locations }\end{array}$ & Soil & Habitats & Flowering & $\begin{array}{l}\text { Wildlife Status } \\
\text { (Past) vs. (Present) }\end{array}$ & References \\
\hline 1 & Lallemantia royleana (Benth.) Benth. & $(\mathrm{RAK}, \mathrm{F})$ & (RA) & (Roc) & $\begin{array}{l}\text { (Mou "medium and } \\
\text { high elevations") }\end{array}$ & Feb. to Apr. & (RA) & [21] \\
\hline 3 & Ocimum forsskaolii Benth. & (S, F, RAK) & (HM, RA) & . & (Plat) & Feb. to Apr. & (NE) (NC) & {$[15,21,28]$} \\
\hline 4 & Salvia aegyptiaca L. & $(\mathrm{AD}, \mathrm{S}, \mathrm{F}, \mathrm{RAK})$ & $(\mathrm{HM})$ & (Roc) & $\begin{array}{c}\text { (Wad, Hil "all } \\
\text { elevations", Mou) }\end{array}$ & Feb. to May. & $(\mathrm{CO})(\mathrm{CO})$ & {$[15,21,22,24,28]$} \\
\hline 5 & Salvia macilenta Boiss. & (F, RAK, AD) & $(\mathrm{EE})$ & (Roc) & $\begin{array}{l}\text { (Plat, Wad, Hil } \\
\text { "low", Mou) }\end{array}$ & Feb. to May. & $(\mathrm{CO})(\mathrm{NC}, \mathrm{CO})$ & {$[15,21,22]$} \\
\hline 6 & Salvia macrosiphon Boiss. & (F, S !, RAK!) & (RA! HM!) & (Roc) & (Wad, Hil, Mou) & Feb. to May. & (RA) & {$[15,21]$} \\
\hline 7 & $\begin{array}{l}\text { Salvia mirzayanii Rech.f. } \\
\text { and Esfandiari }\end{array}$ & (F, RAK) & (RA) & (Roc) & $\begin{array}{c}\text { (Wad, Hil } \\
\text { "low", Mou) }\end{array}$ & Feb to May! & $(\mathrm{NC}) !$ & [21] \\
\hline 8 & Salvia spinosa $\mathrm{L}$. & $(\mathrm{AD}, \mathrm{S}, \mathrm{F}, \mathrm{RAK})$ & (HM, RA) & (Roc) & $\begin{array}{l}\text { (Rod, Wad, Hil “low } \\
\text { to medium } \\
\text { elevations", Mou) }\end{array}$ & Feb. to Apr.! & $(\mathrm{NC}, \mathrm{CO})$ & {$[21,22]$} \\
\hline 9 & Teucrium polium $\mathrm{L}$. & (F, RAK) & (RA) & . & $\begin{array}{l}\text { (Wad, Hil “all } \\
\text { elevations")! }\end{array}$ & Feb. to May.! & (NE) (RA)! & {$[21,28]$} \\
\hline 11 & Zataria multiflora Boiss. & . & . & . & . & . & . & [24] \\
\hline
\end{tabular}

Table 8. Details of EOs isolated from species of Asteraceae/Compositae/Anthemideae.

\begin{tabular}{|c|c|c|c|c|c|c|c|c|}
\hline No. & Botanical Name & Plant Part & $\begin{array}{l}\text { Physical } \\
\text { Properties }\end{array}$ & $\begin{array}{l}\text { Yield } \\
(\%)\end{array}$ & $\begin{array}{l}\text { Isolation } \\
\text { Method }\end{array}$ & Main Chemical Groups/Components & Biological Activity & References \\
\hline 1 & $\begin{array}{c}\text { Anthemis } \\
\text { odontostephana Boiss. }\end{array}$ & $\mathrm{Fl} / \mathrm{L} / \mathrm{St} / \mathrm{R}$ & $\begin{array}{c}\text { (Yellow } \\
\text { color/Aromatic } \\
\text { odor)Fl,HD }\end{array}$ & $\begin{array}{l}\text { (0.2)Fl,HD } \\
\text { (0.7)Fl,HD } \\
\text { (0.5)L,HD } \\
\text { (0.7)St,HD } \\
\text { (0.2)R,HD }\end{array}$ & HD & $\begin{array}{l}\text { (Monoterpene hydrocarbons, oxygenated } \\
\text { monoterpenes, sesquiterpene hydrocarbons, } \\
\text { oxygenated sesquiterpenes, } \\
\text { phenylpropanoids)Fl,HD } \\
\text { (Spathulenol, hexadecanoic acid, } \\
\text { germacrene D, 1,8-cineole, } \\
\text { 6-methyl-5-hepten-2-one, caryophyllene } \\
\text { oxide, } \beta \text {-caryophyllene, camphor)Fl,HD } \\
\text { (Borneol)Fl/L/St,HD } \\
\text { (Pentadecanoic acid)R,HD }\end{array}$ & $\begin{array}{c}\text { [AB/AF/AM]Fl/L/St/R,HD } \\
\text { (AB: Gram-negative bacteria: } \\
\text { Escherichia coli, Escherichia coli, } \\
\text { Klebsiella bacteria. Gram-positive } \\
\text { bacteria: Staphylococcus aureus, } \\
\text { Staphylococcus epidermidis, } \\
\text { Corynebacterium } \\
\text { glutamicum)Fl/L/St/R,HD } \\
\text { (AF: Aspergillus niger, Fusarium } \\
\text { solani species complex, Alternaria } \\
\text { alternata)Fl/L/St/R,HD }\end{array}$ & {$[52,186,187]$} \\
\hline
\end{tabular}


Table 8. Cont.

\begin{tabular}{|c|c|c|c|c|c|c|c|c|}
\hline No. & Botanical Name & Plant Part & $\begin{array}{l}\text { Physical } \\
\text { Properties }\end{array}$ & $\begin{array}{l}\text { Yield } \\
(\%)\end{array}$ & $\begin{array}{l}\text { Isolation } \\
\text { Method }\end{array}$ & Main Chemical Groups/Components & Biological Activity & References \\
\hline 2 & $\begin{array}{c}\text { Artemisia sieberi } \\
\text { Besser }\end{array}$ & $\mathrm{L} / \mathrm{Sh}$ & $\begin{array}{c}\text { Fresh } \\
\text { herbaceous, } \\
\text { camphoraceous, } \\
\text { earthy odor with } \\
\text { a fruity and } \\
\text { dried plum-like } \\
\text { background }\end{array}$ & $\begin{array}{l}\text { (1.7)Sh,HD } \\
\text { (1.02)Sh,SD (0.5 } \\
\text { to 3.5)Sh,HD (1.6 } \\
\text { to } 14.0) \text { Sh,SFE }\end{array}$ & $\mathrm{HD} / \mathrm{SD} / \mathrm{SFE}$ & $\begin{array}{c}\text { (Sesquiterpenes: } \\
\text { dehydro-1,8-sesquicineole)Sh } \\
\text { (camphor, camphene, 1,8-cineol, } \beta \text {-thujone, } \\
\alpha \text {-pinene)Sh,HD } \\
\text { (camphor, 1,8-Cineol)Sh,SFE } \\
\text { ( } \alpha \text { - thujone, } \beta \text { - thujone, camphor) (camphor, } \\
\text { 1,8-cineole, bornyl acetate, neryl } \\
\text { acetate)Sh,SD } \\
\text { (camphene, 1, 8-cineole, trans-thujone, } \\
\text { camphor, borneol)Sh,HD } \\
\text { (camphor, 1,8-cineole, bornyl acetate)Sh,SD } \\
\text { (camphor, camphene, 1,8-cineol, } \beta \text {-thujone, } \\
\alpha \text {-pinene)L,HD } \\
\text { (camphor, 1,8-cineole, camphene, } \\
\text { terpinen-4-ol, } \alpha \text {-terpineol, } \\
\text { dehydro-1,8-sesquicineole)Sh } \\
\text { (ketone, 1, 8 cineole, selin-11-en-4-a-ol, } \\
\text { lavandulon)Sh } \\
(1,8 \text { cineol, myrcene, } 1,8 \text { cineol, } \\
\text { Eudesm-7(11)-en-4-ol, 4-tepinyl acetate, } \\
\text { davanone, p-cymene) }\end{array}$ & $\begin{array}{c}\text { [AB/AF/AM/FT/AD] } \\
\text { (AB: Gram-positive bacteria, } \\
\text { Gram-negative bacteria) } \\
\text { (AM: yeast and fungi) } \\
\text { (AM: Gram-positive bacilli: } \\
\text { Listeria monocytogenes, Bacillus } \\
\text { cereus. Gram-positive cocci: } \\
\text { Streptococcus mutans) } \\
\text { (AB: Pseudomonas aeroginosa, } \\
\text { Staphylococcus aureus, } \\
\text { Escherichia coli)Sh } \\
\text { (FT against insects: Callosobruchus } \\
\text { maculatus, Sitophilus oryzae, } \\
\text { Tribolium castaneum) L,HD } \\
\text { (AF: for patient with } \\
\text { Pityriasis versicolor) }\end{array}$ & [188] \\
\hline 3 & Calendula arvensis $\mathrm{L}$. & Sh & . & $\begin{array}{c}\text { (0.02 to } \\
0.06) \text { Sh,HD }\end{array}$ & $\mathrm{HD}$ & $(\gamma$-cadinene, $\alpha$-cadinol)Sh,HD & . & {$[54,189]$} \\
\hline 4 & Cichorium intybus L. & $\mathrm{Sh} / \mathrm{Fl}$ & $\begin{array}{l}\text { (Yellow } \\
\text { color/Strong } \\
\text { odor)Sh, HD }\end{array}$ & & $\mathrm{HD}$ & $\begin{array}{c}\text { (carvacrol, thymol, cinnamic aldehyde, } \\
\text { camphor, carvone, linalool, } \\
\alpha \text {-terpineol)Sh,HD }\end{array}$ & . & {$[55,190]$} \\
\hline 5 & $\begin{array}{l}\text { Conyza bonariensis } \\
\text { (L.) Cronq. }\end{array}$ & $\mathrm{W} / \mathrm{Sh} / \mathrm{Fl}$ & & $(0.22) \mathrm{W}, \mathrm{SD}$ & $\mathrm{HD} / \mathrm{SD}$ & $\begin{array}{c}\text { (Sesquiterpenes)HD } \\
\text { (Monoterpenes, acetylenes, sesquiterpenes, } \\
\text { diterpenes)W,SD } \\
\text { (matricaria methyl ester, limonene, manool, } \\
\text { carvone)W,SD } \\
\text { ((E)- } \beta \text {-farnesene, germacrene D, } \\
\beta \text {-caryophyllene, limonene)HD } \\
\text { (matricaria ester, (Z)-nerolidol, } \\
\text { caryophyllene oxide)Sh (matricaria ester, } \\
\text { caryophyllene oxide, (E)- } \beta \text {-farnesene)Sh } \\
\text { (matricaria ester, geranyl acetone, } \\
\text { trans- } \alpha \text {-bergamotene, limonene)Sh }\end{array}$ & {$[\mathrm{AB} / \mathrm{AF} / \mathrm{AM} / \mathrm{IS}] \mathrm{HD}$} & {$[191,192]$} \\
\hline
\end{tabular}


Table 8. Cont.

\begin{tabular}{|c|c|c|c|c|c|c|c|c|}
\hline No. & Botanical Name & Plant Part & $\begin{array}{l}\text { Physical } \\
\text { Properties }\end{array}$ & $\begin{array}{c}\text { Yield } \\
(\%)\end{array}$ & $\begin{array}{l}\text { Isolation } \\
\text { Method }\end{array}$ & Main Chemical Groups/Components & Biological Activity & References \\
\hline 6 & Eclipta prostrata L. & $\mathrm{L} / \mathrm{St} / \mathrm{Fl} / \mathrm{Sh}$ & $\begin{array}{c}\text { (Yellow color)Sh, } \\
\text { HD }\end{array}$ & (0.1)Sh,HD & HD & $\begin{array}{c}\text { (Sesquiteprenoids, straight chain } \\
\text { hydrocarbons, monoterpenoids, } \\
\text { P-caryophyllene, a-humulene) } \\
\text { (hydrocarbons with sesquiterpene } \\
\text { predominating, alcohols, ketones, } \\
\text { aldehydes, oxides, esters)Sh,HD } \\
\text { ( } \alpha \text {-Humulene, 6,9-heptadecadiene, } \\
\text { (E)- } \beta \text {-farnesene, } \alpha \text {-phellandrene)Sh,HD } \\
\text { (sesquiterpenoids)L } \\
\text { (sesquiteprenoids, straight chain, } \\
\text { hydrocarbons, monoterpenoids)St } \\
\text { (P-caryophyllene)L } \\
\text { (a-humulene, (E)-beta-farnesene)St }\end{array}$ & . & [57] \\
\hline 7 & Grantia aucheri Boiss. & Sh & . & (0.53)Sh,HD & HD & (Sesquiterpenes: himachalol)Sh,HD & . & {$[58,193]$} \\
\hline 8 & $\begin{array}{l}\text { Launaea nudicaulis } \\
\text { (L.) Hook. f. }\end{array}$ & Sh & . & . & SD & (limonene, Z-citral, E-citral)Sh,SD & $\begin{array}{c}{[\mathrm{AB} / \mathrm{AM}]} \\
\text { (AB: Gram-positive bacteria: } \\
\text { Staphylococcus aureus. } \\
\text { Gram-negative bacteria: } \\
\text { Escherichia coli)Sh,SD }\end{array}$ & {$[59,60]$} \\
\hline
\end{tabular}


Table 8. Cont.

\begin{tabular}{|c|c|c|c|c|c|c|c|c|}
\hline No. & Botanical Name & Plant Part & $\begin{array}{l}\text { Physical } \\
\text { Properties }\end{array}$ & $\begin{array}{l}\text { Yield } \\
(\%)\end{array}$ & $\begin{array}{l}\text { Isolation } \\
\text { Method }\end{array}$ & Main Chemical Groups/Components & Biological Activity & References \\
\hline 10 & $\begin{array}{c}\text { Matricaria } \\
\text { chamomilla L. }\end{array}$ & $\mathrm{Sh} / \mathrm{Fl}$ & $\begin{array}{l}\text { (Dark blue } \\
\text { color/Strong } \\
\text { characteristic } \\
\text { odor)Fl,HD }\end{array}$ & $\begin{array}{l}(0.626 \text { to } \\
0.754) \mathrm{Fl}, \mathrm{HD} \\
(0.25) \mathrm{Fl}, \mathrm{SD} \\
(0.73) \mathrm{Fl}, \mathrm{HD} \\
(4.33) \mathrm{Fl}, \mathrm{SFE}\end{array}$ & $\begin{array}{l}\mathrm{HD} / \mathrm{SD} / \\
\mathrm{SDE} / \mathrm{SFE}\end{array}$ & $\begin{array}{c}\text { (azulene-7-ethyl-1,4-dimethyl, limonene, } \\
\text { bisabolol oxides A and B, bisabolone oxide, } \\
\text { trans- } \beta \text {-farnesen, isobornyl } \\
\text { isobutyrate }<8 \text {-isobutyryloxy>)Fl,HD } \\
\text { ( } \alpha \text {-bisabolol, trans-trans-farnesol, } \\
\text { cis- } \beta \text {-farnesene, guaiazulene, } \alpha \text {-cubebene, } \\
\alpha \text {-bisabolol oxide A, chamazulene)Fl,SD } \\
\text { (Guaiazulene, (E)- } \beta \text {-faranesens, } \\
\text { chamazulene, } \alpha \text {-bisabolol oxide B, } \\
\alpha \text {-bisabolol, hexadecanole)Fl,HD } \\
\text { (Trans-anethole, estragole, fenchone, } \\
\text { limonene)Fl,HD } \\
\text { ((-)- } \alpha \text {-bisabolol, chamazulene, } \\
\text { (-)- } \alpha \text {-bisabololoxides)Fl (chamazulene, } \\
\text { cis-spiroether, trans-spiroether)Fl,SD } \\
(\alpha \text {-bisabolol oxide A and B, (E)- } \beta \text {-farnesene, } \\
\alpha \text {-bisabolol, chamazulene)Fl,HD } \\
\text { (Sesquiterpenoid)Fl,SDE } \\
\text { (Bisabolol oxide, bisabolon oxide, } \\
\beta \text {-farnesense, } \alpha \text {-bisabolol, chamazulene and } \\
\text { en-yn-dicycloether)Fl,SDE } \\
\text { (bisabolol oxide A, } \alpha \text {-bisabolol, bisabolol } \\
\text { oxide B, cis-enyne-bicycloether, bisabolon } \\
\text { oxide A, chamazulene, spathulenol, } \\
\text { (E)- } \beta \text {-farnesene) } \\
\text { ( } \beta \text {-farnesene, } \alpha \text {-farnesene, } \gamma \text {-cadinene, } \\
\alpha \text {-bisabolol oxide B, } \alpha \text {-bisabolol, } \\
\text { chamazulene, } \alpha \text {-bisabolol oxide A, cis, } \\
\text { trans-dicycloether)Fl,SFE } \\
((E)-\beta \text {-farnesene, guaiazulene, } \alpha \text {-bisabolol } \\
\text { oxide A, } \alpha \text {-farnesene, } \alpha \text {-bisabolol)Sh }\end{array}$ & $\begin{array}{c}\text { [AB/AF/AM/AO/AS] } \\
\text { (AF: Aspergillus niger)Fl,SD } \\
\text { (AB: Streptoccus pygenes, } \\
\text { Streptococcus mutans, Streptococcus } \\
\text { salivarius, Streptococcus faecalis, } \\
\text { Streptococcus sanguis)Fl,HD } \\
\text { (AM: Aspergillus flavus, Candida } \\
\text { albicans, Bacillus cereus, } \\
\text { Staphylococcus aureus)Fl,HD }\end{array}$ & {$[107,195]$} \\
\hline 11 & $\begin{array}{c}\text { Pluchea arabica } \\
\text { (Boiss.) Qaiser and } \\
\text { Lack }\end{array}$ & $\mathrm{Sh} / \mathrm{Fl}$ & . & (0.08)Sh,SD & SD & $\begin{array}{c}\text { (Sesquiterpene)Sh,SD } \\
\text { (8-cadinol, 9-(1-methylethylidene)- } \\
\text { bicyclo[6.1.0]nonane, caryophyllene oxide, } \\
\text { methyleugenol, } \beta \text {-caryophyllene)Sh,SD } \\
\text { (godotol A and godotol B) }\end{array}$ & $\begin{array}{c}{[\mathrm{AB} / \mathrm{AM}]} \\
\text { (AB: Staphylococcus aureus, } \\
\text { Candida albicans, Bacillus } \\
\text { subtilis)Sh,SD }\end{array}$ & {$[64,66]$} \\
\hline
\end{tabular}


Table 8. Cont.

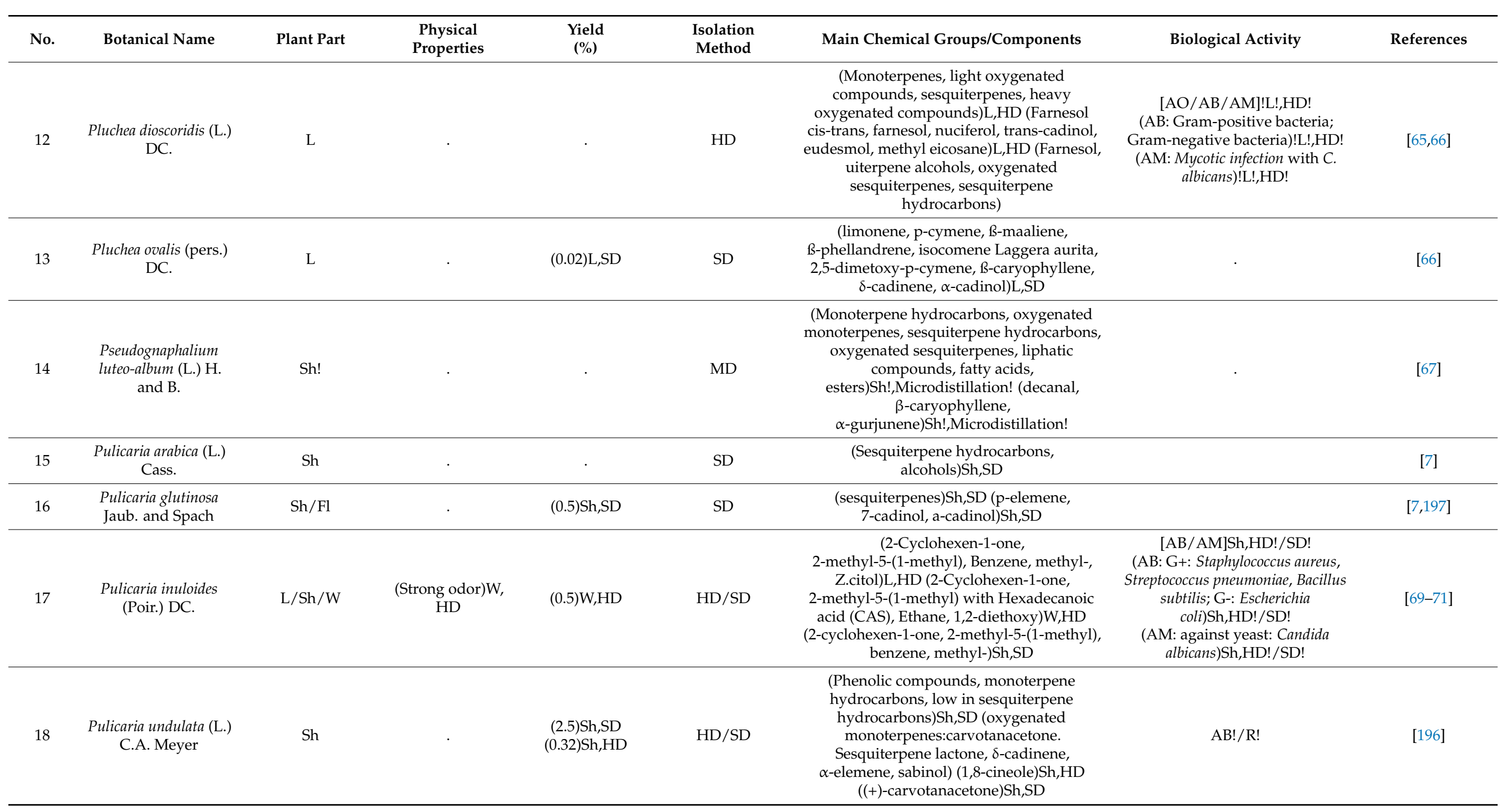


Table 8. Cont.

\begin{tabular}{|c|c|c|c|c|c|c|c|c|}
\hline No. & Botanical Name & Plant Part & $\begin{array}{l}\text { Physical } \\
\text { Properties }\end{array}$ & $\begin{array}{l}\text { Yield } \\
(\%)\end{array}$ & $\begin{array}{l}\text { Isolation } \\
\text { Method }\end{array}$ & Main Chemical Groups/Components & Biological Activity & References \\
\hline 19 & $\begin{array}{l}\text { Rhanterium } \\
\text { epapposum Oliv. }\end{array}$ & Sh!/Fl! & . & $0.25 !$ & HD! & $\begin{array}{l}\text { (Terpenoids, Non-terpenoid aliphatic and } \\
\text { aromatic structures) (terpenoids: } \\
\alpha \text {-phellandrene, linalol, geraniol, bulnesol) } \\
(\alpha \text {-phellandrene, linalol, geraniol, bulnesol, } \\
\beta \text {-phellandrene) }\end{array}$ & . & [197] \\
\hline 20 & $\begin{array}{l}\text { Senecio glaucus L. ssp. } \\
\text { coronopifolius } \\
\text { (Maire) Al. }\end{array}$ & Sh!/Fl!/Fr! & $\begin{array}{l}\text { (Apricot-like } \\
\text { odor "while the } \\
\text { odor of the intact } \\
\text { plant is } \\
\text { herbaceous, } \\
\text { spicy and floral } \\
\text { fruity")SD/H }\end{array}$ & . & $\mathrm{SD} / \mathrm{H}$ & $\begin{array}{l}\text { (Monoterpenes,Sesquiterpenes)SD/H } \\
\text { (myrcene, dehydrofukinone)SD/H }\end{array}$ & . & [198] \\
\hline 21 & $\begin{array}{l}\text { Seriphidium herba-alba } \\
\text { (Asso) Sojak }\end{array}$ & $\mathrm{L} / \mathrm{Fl} / \mathrm{Sh}$ & $\begin{array}{l}\text { (Yellow } \\
\text { color)L/Fl,HD }\end{array}$ & (1.45)L/Fl, HD & $\mathrm{HD}$ & $\begin{array}{l}\text { (Oxygenated monoterpenes, oxygenated } \\
\text { sesquiterpenes)L/Fl,HD } \\
\text { (cis-chrysantenyl acetate, the sabinyl acetate } \\
\text { and the } \alpha \text {-thujone)L/Fl,HD }\end{array}$ & $\begin{array}{c}\text { [AB/AF/AM]Sh,HD } \\
\text { [AO/AM]L/Fl,HD } \\
\text { (AM: S. typhimurium, E. coli, K. } \\
\text { pneumoniae, P. aeruginosa, E. } \\
\text { faecalis, B. cereus, F. solani, A. } \\
\text { oxysporum)L/Fl,HD }\end{array}$ & [76] \\
\hline
\end{tabular}


Table 9. Details of EOs isolated from species of Fabaceae/Leguminosae/Papilionoideae.

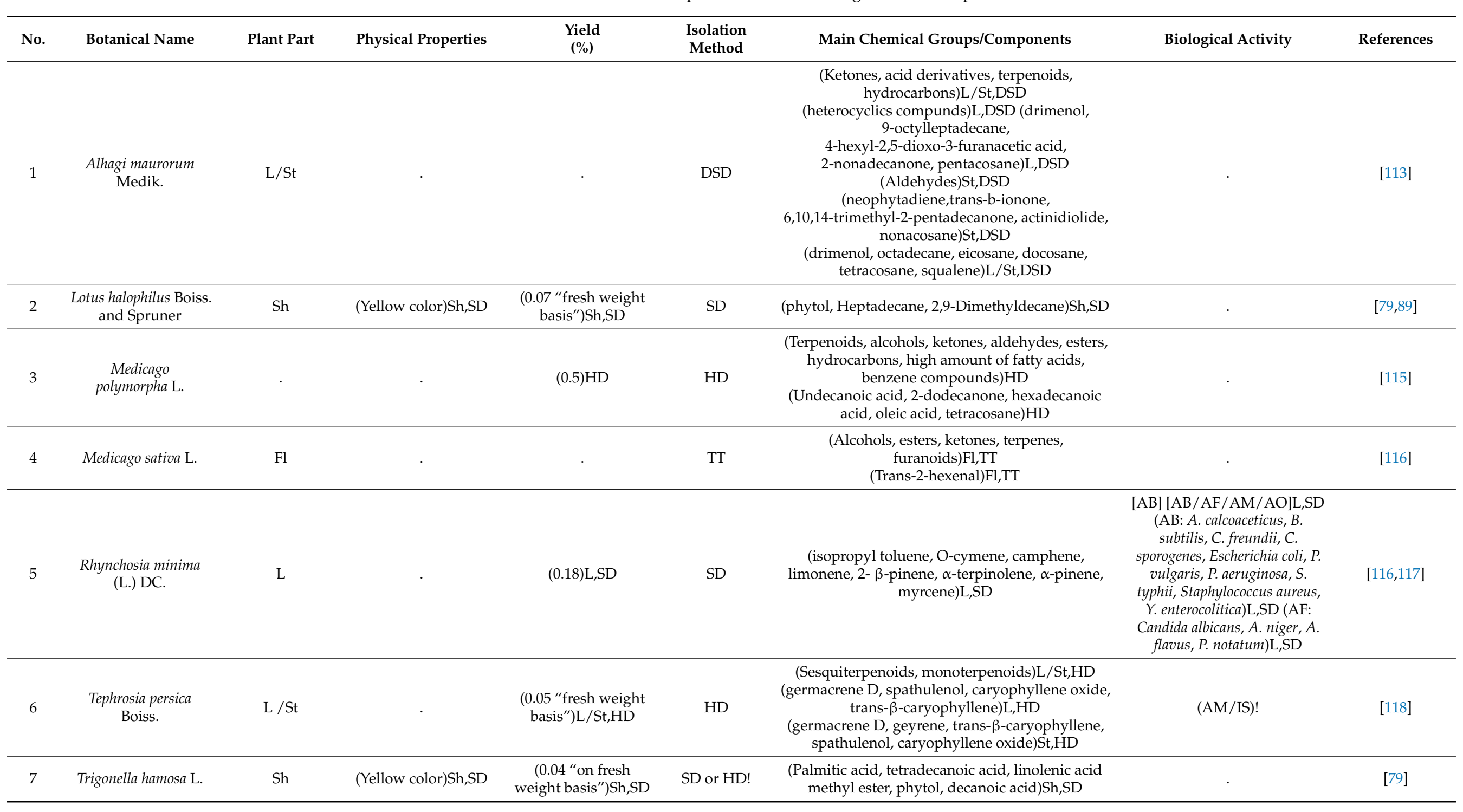


Table 9. Cont.

\begin{tabular}{|c|c|c|c|c|c|c|c|c|}
\hline No. & Botanical Name & Plant Part & Physical Properties & $\begin{array}{l}\text { Yield } \\
(\%)\end{array}$ & $\begin{array}{l}\text { Isolation } \\
\text { Method }\end{array}$ & Main Chemical Groups/Components & Biological Activity & References \\
\hline 8 & Ononis sicula Guss. & . & & . & & $\begin{array}{l}\text { (Oxygenated sesquiterpenes, sesquiterpene } \\
\text { hydrocarbons) (sesquiterpene hydrocarbons: } \\
\text { selin-11-en- } 4-\alpha \text {-ol, } \alpha \text {-selinene) }\end{array}$ & {$[\mathrm{AO}]$} & [119] \\
\hline 9 & $\begin{array}{l}\text { Acacia nilotica (L.) } \\
\text { Delile }\end{array}$ & $\mathrm{St} / \mathrm{Pd} / \mathrm{Bk}$ & & $\begin{array}{c}(0.08) \mathrm{St}, \mathrm{HD} \\
(4.56) \mathrm{Pd}, \mathrm{SFE} \\
(4.86,5.05) \mathrm{Bk}, \mathrm{SFE}\end{array}$ & $\mathrm{HD} / \mathrm{SFE}$ & $\begin{array}{l}\text { (Monoterpenoid compounds, } \\
\text { sesquiterpenes)St,HD } \\
\text { (Monoterpenoid compounds: menthol, limonene. } \\
\alpha \text {-Curcumene, carvacrol)St,HD }\end{array}$ & $\begin{array}{l}\text { [AB/AF/AM] } \\
\text { (AB: Bacillus } \\
\text { subtilis)Pd!/Bk!,SFE } \\
\text { (AF: Ganoderma } \\
\text { lucidum)Pd!/Bk!,SFE }\end{array}$ & [120] \\
\hline 10 & $\begin{array}{l}\text { Acacia tortilis } \\
\text { (Forssk.) Hayne }\end{array}$ & $\mathrm{L}$ & $\begin{array}{l}\text { (Yellow-green } \\
\text { color)L,GC-FID }\end{array}$ & (0.12)L,GC-FID & GC-FID & $\begin{array}{c}\text { (Monoterpenes, rich sesquiterpenoid } \\
\text { compounds)L,GC-FID } \\
\text { ( } \alpha \text {-humulene, } \alpha \text {-cadinol, nerolidol, } \gamma \text {-cadinene, } \\
\text { 2-(E)-octenal)L,GC-FID }\end{array}$ & . & [122] \\
\hline 11 & $\begin{array}{l}\text { Prosopis farcta (Banks } \\
\text { and Sol.) Mac. }\end{array}$ & $\begin{array}{c}\mathrm{St} / \mathrm{Pd} / \mathrm{L} / \\
\mathrm{Fl} / \mathrm{Se} / \mathrm{R} / \mathrm{W}\end{array}$ & (Pleasant odor)W,SD & $\begin{array}{c}(0.00472 \text { to } \\
0.00793) W, S D\end{array}$ & SD & $\begin{array}{c}\text { (Saturated hydrocarbons, unsaturated } \\
\text { hydrocarbons, aldehydes, carboxylic acids)Sh,SD } \\
\text { (Heneicosane, 6,10,14-Trimethylpentadecan- } \\
\text { 2-one, Docosane, } \\
\text { 2-Methyl-1-tertiobutilprop-1,3-yl-, D-Limonene, } \\
\text { Methyl hexadecanoate)St,SD (Phytol, Benzyl } \\
\text { benzoate, 3-Hydroxy-beta-damascone)L,SD } \\
\text { (Phytol, Tetradeca-1,13-diene, Eicosane)Fl,SD } \\
\text { (Methyl octadec-9-enoate, Phytol, Methyl } \\
\text { hexadecanoate)Pd,SD } \\
\text { (Octadecanal, Hexadecanal, Heptadeca-1, } \\
\text { 11,13-triene)R,SD }\end{array}$ & . & {$[122,128]$} \\
\hline
\end{tabular}

Table 10. Details of EOs isolated from species of Lamiaceae/Labiatae.

\begin{tabular}{|c|c|c|c|c|c|c|c|c|}
\hline No. & Botanical Name & Plant Part & Physical Properties & $\begin{array}{l}\text { Yield } \\
(\%)\end{array}$ & $\begin{array}{l}\text { Isolation } \\
\text { Method }\end{array}$ & Main Chemical Groups/Components & Biological Activity & References \\
\hline 1 & $\begin{array}{l}\text { Lallemantia royleana } \\
\text { (Benth.) Benth. }\end{array}$ & $\mathrm{L} / \mathrm{St} / \mathrm{Fl} / \mathrm{Sh}$ & . & . & HD & $\begin{array}{l}\text { (trans-pinocarvyl acetate, pinocarvone, } \beta \text {-pinene, } \\
(\text { E)- } \beta \text {-ocimene, terpinolene, linalool, trans- } \\
\text { pinocarveol, 3-thujen-2-one, myrtenal, verbenone, } \\
\text { trans-carveol, cis-carveol, pulegone, carvacrol, } \\
\text { dihydrocarvyl acetate, } \beta \text {-cubebene)Sh,HD }\end{array}$ & $\begin{array}{c}\text { [ AB/AF/AM]Sh,HD } \\
\text { (AB: Staphylococcus aureus, } \\
\text { Bacillus subtilis, Klebsiella } \\
\text { pneumoniae)Sh,HD (AF: } \\
\text { Candida albicans, Aspergillus } \\
\text { niger)Sh,HD }\end{array}$ & [128] \\
\hline
\end{tabular}


Table 10. Cont.

\begin{tabular}{|c|c|c|c|c|c|c|c|c|}
\hline No. & Botanical Name & Plant Part & Physical Properties & $\begin{array}{c}\text { Yield } \\
(\%)\end{array}$ & $\begin{array}{l}\text { Isolation } \\
\text { Method }\end{array}$ & Main Chemical Groups/Components & Biological Activity & References \\
\hline 2 & Mentha spicata & $\mathrm{L} / \mathrm{Sh}$ & $\begin{array}{l}\text { (Light green } \\
\text { color)L,HD }\end{array}$ & $\begin{array}{l}(0.53) \text { Sh,HD } \\
(0.566 \pm 0.02 \text { “on } \\
\text { fresh weight } \\
\text { basis")L,HD } \\
\text { (1.2)Sh,HD!orSD! } \\
\text { (0.1 to } 1.8) \text { Sh!orL! } \\
\text { (0.9)Sh,SD } \\
\text { (0.32)Sh,SD SFE }\end{array}$ & $\mathrm{HD} / \mathrm{SD} / \mathrm{SFE}$ & $\begin{array}{c}\text { (Oxygenated, non-oxygenated monoterpenes, } \\
\text { sesquiterpenes)SD (carvacrol, thymol) } \\
\text { (Carvone, Trans carveol)Sh,HD } \\
\text { (piperitone oxide, piperitenone oxide, carvone, } \\
\text { dihydrocarvone)L,HD } \\
\text { (carvone, limonene, 1,8-cineole, } \\
\text { trans-carveol)L,HD } \\
\text { (carvone, cis-carveol, limonene, 1,8 cineol, } \\
\text { cis-dihydrocarvone, carvyl acetate, cis-sabinene } \\
\text { hydrate)Sh,HD!or SD! } \\
\text { (carvone, menthone)HD } \\
\text { (linalool, germacrene D, } \beta \text {-caryophyllene, 1,8 } \\
\text { cineole)Sh!orL! (menthol, menthone) (carvone, } \\
\text { limonene, 1,8-cineole, menthone, linalool, } \\
\text { isomenthone)Sh,SD (piperitenone oxide)Sh,SD } \\
\text { (menthol, carvone, D-Limonene)L,HD } \\
\text { (piperitenone oxide)Sh,HD } \\
\text { (carvone, cis-carveol, limonene)L (Carvone, } \\
\text { Limonene, Cineole, Linalool, Menthol, } \\
\text { Dihydrocarvone)SD } \\
\text { (Carvone, Limonene, a-pinene, Cineole, Linalool, } \\
\text { Menthol, Dihydrocarvone)SFE }\end{array}$ & $\begin{array}{c}\text { [AB/AF/AM/AO/IS/MP] } \\
\text { Sh,HD!orSD! } \\
\text { [IS/LA/MR]L (LA and MR: } \\
\text { against Culex quinquefasciatus, } \\
\text { Aedes aegypti, Anopheles } \\
\text { stephensi)L } \\
\text { (AO: good } \\
\text { activity)Sh,HD!orSD! (AO: } \\
\text { good activity)L,HD } \\
\text { (strong AB: Staphylococcus } \\
\text { aureus, Escherichia coli, } \\
\text { Bacillus subtilis, Pasturella } \\
\text { multocida)Sh,HD!orSD! } \\
\text { (strong AF: Aspergillus niger, } \\
\text { Mucor mucedo, Fusarium } \\
\text { solani, Botryodiplodia } \\
\text { theobromae, Rhizopus } \\
\text { solani)Sh,HD!orSD! } \\
\text { (AM: Enterococcus faecium, } \\
\text { Salmonella cholerasuis, B. } \\
\text { subtilis)Sh,SD }\end{array}$ & [199] \\
\hline 3 & $\begin{array}{l}\text { Ocimum forsskaolii } \\
\text { Benth. }\end{array}$ & $\mathrm{L} / \mathrm{Fl} / \mathrm{Sh}$ & & $\begin{array}{l}(0.45 \text { to } 0.47) \mathrm{L}, \mathrm{SD} \\
(0.6 \text { to } 0.96) \mathrm{Fl}, \mathrm{SD}\end{array}$ & $\mathrm{HD} / \mathrm{SD} / \mathrm{H}$ & $\begin{array}{c}\text { (estragole, linalool)L/Fl/Sh,SD } \\
\text { (linalool, methyl chavicol, (E)-methyl cinnamate, } \\
\text { myrcene, eugenol) } \\
\text { ((R)-(-)-linalool, (S)-(+)-1-octen-3-ol, } \\
\text { trans-caryophyllene, naphthalene, } \\
\text { methyl salicylate, (R)-(-)-a-copaene, methyl } \\
\text { cinnamate, (E)-ocimene) } \\
\text { (benzene, methyl-)Sh,SD } \\
\text { (Bicyclo hept-2-ene, 2, naphthalene, phytol)Sh,SD }\end{array}$ & $\begin{array}{c}\text { [AB/AF/AM]L,SD } \\
\text { [AO]Sh,SD (MR: against } \\
\text { female Anopheles } \\
\text { gambiae)Sh,HD } \\
\text { (MR: Aedes aegypti)H } \\
\text { (weak AF: against } \\
\text { Dermatophytes)L,SD } \\
\text { (AM: Candida albicans)Sh,SD }\end{array}$ & {$[69,131]$} \\
\hline 4 & Salvia aegyptiaca L. & $\mathrm{W}$ & $\begin{array}{l}\text { (Yellow color/same } \\
\text { plant odor)W,SD }\end{array}$ & $(0.033 !) \mathrm{W}, \mathrm{SD}$ & $\mathrm{SD}$ & $\begin{array}{l}\text { (Terpenoidal constituents, fat derivatives)W,SD } \\
\text { (Aristolene, diphenyl amine, methyl } \\
\text { palmitate)W,SD }\end{array}$ & . & [2] \\
\hline 5 & Salvia macilenta Boiss. & $\mathrm{Sh} / \mathrm{W}$ & . & . & HD & $\begin{array}{c}\text { (Rich in monoterpene hydrocarbons)Sh,HD } \\
\text { ( } \gamma \text {-elemene, thymol, elemol, } \\
\beta \text {-caryophyllene)Sh,HD }\end{array}$ & . & {$[3]$} \\
\hline
\end{tabular}


Table 10. Cont.

\begin{tabular}{|c|c|c|c|c|c|c|c|c|}
\hline No. & Botanical Name & Plant Part & Physical Properties & $\begin{array}{c}\text { Yield } \\
(\%)\end{array}$ & $\begin{array}{c}\text { Isolation } \\
\text { Method }\end{array}$ & Main Chemical Groups/Components & Biological Activity & References \\
\hline 6 & $\begin{array}{c}\text { Salvia macrosiphon } \\
\text { Boiss. }\end{array}$ & Sh & (Yellow color)Sh,HD & $\begin{array}{l}(0.14) \mathrm{Sh}, \mathrm{HD}(0.14 \\
\text { to 0.23)Sh, HD } \\
(0.5) \mathrm{Sh}, \mathrm{HD}\end{array}$ & $\mathrm{HD} / \mathrm{SD}$ & $\begin{array}{c}\text { (Sesquiterpenes, } \alpha \text {-Gurjunene, } \beta \text {-Cubebene, } \\
\text { Germacrene-B)SD } \\
\text { (linalool, hexyl hexanoate, hexyl isovalerate, } \\
\text { hexyl-2-methyl-butanoate, sclareol, hexyl } \\
\text { octanoate)Sh,HD } \\
\text { ( } \delta \text {-Cadinen and Sclareol, Franesol, } \delta \text {-Amorphene } \\
\text { Caryophyllene oxide, Hexyl octanoate, Beta } \\
\text { Eudesmol, } \alpha \text {-Bisabolol, } \alpha \text {-Muurolol, Decanoic } \\
\text { acid, Manoyl oxide, Manool)Sh,HD } \\
\text { (Sclareol, (+) Spathulenol, (-)-Aristolenel, } \\
\beta \text {-Elemene, Hexyl n-valerate, Germacrene D, } \\
\beta \text {-Eudesmol)Sh,HD (linalool, hexil isovalrate, } \\
\text { hexil 2-methyl buterat, } \delta \text {-cadinen) (piperitone) }\end{array}$ & $\begin{array}{l}\text { [AM] (AM: Streptococcus } \\
\text { pneumoniae, Klebsiella } \\
\text { pneumoniae, Staphylococcus } \\
\text { aureus, Escherichia coli, } \\
\text { Staphylococcus epidermidis) }\end{array}$ & {$[140,141]$} \\
\hline 7 & $\begin{array}{l}\text { Salvia mirzayanii } \\
\text { Rech.f. and } \\
\text { Esfandiari }\end{array}$ & Sh & (Yellow color)Sh,HD & $\begin{array}{c}\text { (2.2)Sh,HD } \\
\text { (11.2)MW (0.50 to } \\
\text { 9.67)SFE }\end{array}$ & $\mathrm{HD} / \mathrm{MW} / \mathrm{SFE}$ & $\begin{array}{c}\text { (linalyl acetate, 1,8-cineole, linalool, 8-acetoxy } \\
\text { linalool)HD/SFE } \\
\text { (linalyl acetate, linalool, 1,8-cineol, 8-acetoxy, } \\
\text { linalool, a-terpineole, E-anethole, d-cadinene)HD } \\
\text { (linalyl acetate)SFE } \\
\text { (spathulenol, } \gamma \text {-cadinene, linalool, } \alpha \text {-terpinyl } \\
\text { acetate, } \alpha \text {-cadinol, } \beta \text {-eudesmol, cubenol, linalyl } \\
\text { acetate)Sh,HD } \\
\text { ( } \alpha \text {-terpinenyl acetate, } 1,8 \text {-cineol, linalool)Sh } \\
\text { (linalyl acetate, linalool, } \alpha \text {-terpinyl acetate, } \\
\text { 1,8-cineol, } \alpha \text {-terpineol, } \delta \text {-cadinene)HD }\end{array}$ & $\begin{array}{l}{[\mathrm{AM}] \mathrm{Sh}[\mathrm{AB}] \text { (AM: good }} \\
\text { activity)Sh (AB: against E.coli, } \\
\text { S.aureus, K.pneumonia, } \\
\text { B.subtilis, P.aeroginosa) }\end{array}$ & [200] \\
\hline 8 & Salvia spinosa L. & Sh & (Yellow color)Sh,HD & $\begin{array}{c}(0.2) \mathrm{Sh}, \mathrm{HD}(0.02) \mathrm{Sh}, \\
\mathrm{HD}\end{array}$ & $\mathrm{HD} / \mathrm{SD}$ & $\begin{array}{c}\text { (High amounts of monoterpene derivatives, low } \\
\text { amounts of sesquiterpenes, phenylpropanoids, } \\
\text { aliphatic esters)Sh,HD (thymol)Sh,HD } \\
\text { (1,8-cineol, (z)- } \beta \text {-ocimene, germacrene d, 2-Butyl } \\
\text { thiophene, trans caryophyllene, 3-Butyl } \\
\text { thiophene)Sh,HD } \\
\text { ((E)- } \beta \text {-ocimene, } \beta \text {-caryophyllene, isopentyl } \\
\text { isovalerate)Sh,SD }\end{array}$ & $\begin{array}{c}\text { [AB/AM]Sh,HD } \\
\text { (AB: Staphylococcus aureus, } \\
\text { Basillus subtilis, Psedomonas } \\
\text { aeruginosa)Sh,HD }\end{array}$ & [136] \\
\hline
\end{tabular}


Table 10. Cont.

\begin{tabular}{|c|c|c|c|c|c|c|c|c|}
\hline No. & Botanical Name & Plant Part & Physical Properties & $\begin{array}{l}\text { Yield } \\
(\%)\end{array}$ & $\begin{array}{l}\text { Isolation } \\
\text { Method }\end{array}$ & Main Chemical Groups/Components & Biological Activity & References \\
\hline 9 & Teucrium polium $\mathrm{L}$. & $\mathrm{L} / \mathrm{St} / \mathrm{Sh}$ & (Yellow color)Sh,SD & $\begin{array}{c}(0.8 \pm 0.04) \mathrm{Sh}, \mathrm{HD} \\
(0.8)(1.7)(0.2) \mathrm{Sh}, \mathrm{HD} \\
(0.75) \mathrm{L} / \mathrm{St}, \mathrm{HD} \\
(1.2) \mathrm{Sh}, \mathrm{HD}(0.21) \mathrm{Sh}, \\
\text { SD SFE }\end{array}$ & $\mathrm{HD} / \mathrm{SD} / \mathrm{SFE}$ & $\begin{array}{c}\text { (Sesquiterpenes, Germacrene D, } \\
\beta \text {-caryophyllene)HD/SFE (terpenoidal } \\
\text { compounds, rich in alcohols, esters) } \\
\text { (8-cedren-13-ol, } \beta \text {-caryophllene, germacrene D, } \\
\text { sabinene)Sh,HD } \\
(\alpha \text {-pinene, } \beta \text {-pinene, p-cymene) ( } \alpha \text {-cadinol, } \\
3 \beta \text {-hydroxy- } \alpha \text {-muurolene, } \alpha \text {-pinene, } \\
\beta \text {-pinene)Sh,HD } \\
\text { ( } \beta \text {-pinene, limonene, } \alpha \text {-phellandrene and } \gamma \text { - and } \\
\delta \text {-cadinenes. Alcohols: linalool, terpine-4-ol, } \\
\text { cedrol, cedrenol, guaiol) (a-pinene, linalool, } \\
\text { caryophyllene oxide, b-pinene, } \\
\text { b-caryophyllene)L/St,HD (germacrene D, } \\
\text { bicyclogermacrene, } \beta \text {-pinene, carvacrol)Sh,SD } \\
(\beta \text {-pinene, } \beta \text {-caryophyllene, } \alpha \text {-pinene, } \\
\text { caryophyllene oxide, myrcene, germacrene-D)Sh }\end{array}$ & $\begin{array}{c} \\
\text { [GP]Sh,HD [ASP] } \\
\text { [ASP]Sh,HD [AB]HD } \\
\text { [moderate AM]Sh,SD } \\
\text { (AB: against Bacillus } \\
\text { cereus)HD (AM: moderate } \\
\text { effect against Bacillus cereus, } \\
\text { Enterococcus faecalis, } \\
\text { Escherichia coli, Staphylococcus } \\
\text { aureus)Sh,SD }\end{array}$ & [137] \\
\hline 10 & $\begin{array}{c}\text { Teucrium stocksianum } \\
\text { Boiss. }\end{array}$ & $\mathrm{Sh} / \mathrm{Fl}$ & $\begin{array}{l}\text { (Light yellow } \\
\text { color)Sh, HD }\end{array}$ & $\begin{array}{l}\text { (0.34)Sh, HD } \\
(0.4) S h, H D\end{array}$ & HD & $\begin{array}{c}\text { (Sesquiterpenoids rich, cis-sesquisabinene hydrate } \\
\text { rich, epi- } \beta \text {-bisabolol, guaiol, } \beta \text {-eudesmol, } \\
\text { monoterpenoids rich)Sh,HD } \\
\text { (a-cadinol, 6-cadinene, seychellene, } \\
\text { P-caryophyllene, germacrene-D-4-01, germacrene } \\
\mathrm{D}, \gamma \text {-cadinene, a-muurolene, valencene)Sh,HD } \\
\text { (camphene, } \alpha \text {-cadinol, myrcene, carvacrol)HD } \\
\text { (Monoterpenoids: } \alpha \text {-pinene, } \beta \text {-pinene, myrcene, } \\
\text { sabinene)Sh,HD }\end{array}$ & {$[\mathrm{AN}] \mathrm{Sh}, \mathrm{HD}$} & [6] \\
\hline
\end{tabular}


Table 10. Cont.

\begin{tabular}{|c|c|c|c|c|c|c|c|c|}
\hline No. & Botanical Name & Plant Part & Physical Properties & $\begin{array}{l}\text { Yield } \\
\text { (\%) }\end{array}$ & $\begin{array}{l}\text { Isolation } \\
\text { Method }\end{array}$ & Main Chemical Groups/Components & Biological Activity & References \\
\hline 11 & $\begin{array}{c}\text { Zataria multiflora } \\
\text { Boiss. }\end{array}$ & $\mathrm{L} / \mathrm{Sh}$ & . & $\begin{array}{c}\text { (3)SD }(2.8) \mathrm{HD} \\
(1.59 \pm 0.86 \text { to } \\
0.99 \pm 0.29) \mathrm{Sh}, \\
\text { HD } \\
(1.66,1.71,2.8)(0.82 \\
\text { to } 0.97) \mathrm{Sh}, \mathrm{HD}(3.66, \\
\text { 3.44)MW }\end{array}$ & $\begin{array}{l}\mathrm{HD} / \mathrm{SD} / \\
\mathrm{MW} / \mathrm{SFE}\end{array}$ & $\begin{array}{c}\text { (Rich oxygenated monoterpens)Sh,HD (phenolic } \\
\text { monoterpenes, glycosides of monoterpenes, } \\
\text { polyhydroxy monoterpenes, benzoic acid } \\
\text { derivatives, alkanes, } \beta \text {-sitosterol, betulin, fatty } \\
\text { acids, oleanolic acid) } \\
\text { (thymol, } \lambda \text {-terpinene, } \rho \text {-cymene)SD/SFE } \\
\text { (carvacrol, thymol, p-cymene, linalool, } \\
\alpha \text {-terpineol) } \\
\text { (thymol, carvacrol, para-cymene, c-terpinene, } \\
\text { b-caryophyllene)HD } \\
\text { (Thymol, carvacrol, } \rho \text {-cymene)Sh,HD (thymol, } \\
\text { carvacrol, p-cymene, linalool, } \gamma \text {-terpinene) } \\
(\gamma \text {-terpinene, } \alpha \text {-pinene, eucaliptol, globulol)SD } \\
\text { (oxygen-containing monoterpenes, sesquiterpene } \\
\text { hyrocarbons, monoterpene hydrocarbons)Sh } \\
\text { (linalol, linalyl acetate, } \beta \text {-caryophyllene)Sh } \\
\text { (thymol, a phenolic compound of oxygenated } \\
\text { monoterpens)Sh,HD } \\
\text { (carvacrol, thymol, linalool, p-cymene)Sh,HD }\end{array}$ & $\begin{array}{l}\text { [IS]Sh [AB/AO]HD [AF]SD } \\
\text { [AF]Sh,HD [AM]Sh,SD } \\
\text { [strong AO]Sh,HD [CE] } \\
\text { (AB: strong activity especially } \\
\text { against G-bacteria. } \\
\text { Staphylococcus aureus, } \\
\text { Escherichia coli, Klebsiella } \\
\text { pneumoniae, Staphylococcus } \\
\text { epidermidis, Enterococcus } \\
\text { faecalis, Bacillus subtilis, } \\
\text { Salmonella typhi, Seratia } \\
\text { marcescens, Shigella } \\
\text { flexneri)HD } \\
\text { (AB: Staphylococcus } \\
\text { aureus)Sh,HD (IS: against } \\
\text { Rhyzopertha dominica, } \\
\text { Togoderma granarium)Sh } \\
\text { (AF: against aflatoxin by } \\
\text { Aspergillus flavus)SD } \\
\text { (AM: Bacillus cereus, } \\
\text { Salmonella Typhimurium, } \\
\text { Staphylococcus aureus)Sh,SD } \\
\text { (AB: Staphylococcus aureus, } \\
\text { Escherichia coli)L } \\
\text { (G+: Bacillus subtilis, } \\
\text { Staphylococcus epidermidis. G-: } \\
\text { Pseudomonas aeroginosa, } \\
\text { Escherichia coli. Pathogenic } \\
\text { yeasts: Candida albicans, } \\
\text { Candida tropicalis)Sh,HD }\end{array}$ & [141] \\
\hline
\end{tabular}


The results of the top three richest families, based on the number of their species, are illustrated from Tables 2-10, including Asteraceae, Fabaceae and Lamiaceae.

The results showed that the taxa of all the UAE EO-bearing plants belongs to the dicotyledon group, except taxa of 15 plants that belong to the monocotyledon group: Phoenix dactylifera, Cyperus arenarius, Cyperus conglomeratus, Cyperus rotundus, Gynandriris sisyrinchium, Dipcadi erythraeum, Cenchrus ciliaris, Cynodon dactylon, Desmostachya bipinnata, Lolium rigidum, Cymbopogon commutatus, Cymbopogon jwarancusa, Cymbopogon schoenanthus, Alpinia galangal, Zingiber officinale.

According to our extensive literature review, the Iranian plants show the highest number of publications in the field of EO research. Other important plants' countries of origin in conducting EOs research include India, Saudi Arabia, Tunisia, Nigeria, Jordan and Pakistan.

On the other hand, there are only a few publications that studied the EO-bearing plants of the UAE. Examples of such studies are mainly by Al Yousuf et al. [7], who studied the EO of Pulicaria glutinosa grown in Jebal Al Faya, and Al Yousuf et al., [6] who studied Teucrium stocksianum grown in Khor Fakkan. Additional research studied EOs of Haplophyllum tuberculatum for plants also grown in Khor Fakkan [5]. Al-Marzouqi et al., [130] studied EO of Menthe spicata collected from different regions in the UAE.

Based on the above, there is scarcity in research performed on the EO-bearing plants of the UAE. This is the case while the country has rich biodiversity and has rich traditional medicine applications $[16,17,28]$. In addition, according to Sakkir et al., [28] 37\% of the UAE medicinal plants are applied topically to treat skin problems. This is a direct/indirect indication that the UAE is a good niche for EO phytochemicals of healing benefits. Consequently, it is highly recommended to invest more efforts to study the local EO-bearing plants, seeking new natural resources of phytochemicals of proven biological activity to the country and the world.

Actually, our established databank of the UAE EO-bearing plants offers a solid background to take quick decisions in plant selection and to start up an innovative EOs-based research pathway, which can lead to new chemotypes and promising discoveries. Besides, the databank provides the interested parties (from academic and industrial fields) the opportunity to have an overview on all the Emirati EO-bearing plants, enabling them to highlight the most important indigenous species to supply their needs according to field of interest. At the same time, the databank lists all the UAE EO-bearing plants that need to be conserved from decision-makers to guarantee a sustainable future for the next generation.

It worth mentioning that rich traditional practices are linked (directly or indirectly) to the availability of EOs as active components that lead to particular biological activities of great healing benefits. Additionally, it was reported by a study conducted by Sakkir et al., [28] from the Environmental Agency of Abu Dhabi (EAD) that 37\% of the indigenous plants have been used to treat skin problems in the traditional medicine of the UAE. Which can be linked, in one way or another, to the presence of therapeutic grade $\mathrm{EO}$, and therefore could be a positive indicator that the flora of the UAE could pose an excellent resource for $\mathrm{EO}$ phytochemicals of various industrial applications.

Thus, it is fundamental to create a comprehensive reference that includes all the UAE indigenous and naturalized species capable of producing EOs. Focusing on the significant role of such a natural resource in a region where fresh water is expensive and where the country's leadership is working on diversifying the economic resources.

Indeed, it is expected that the essential oil of many indigenous and naturalized medicinal and aromatic plants has not been investigated yet, and the true estimation of the EO-bearing plants growing in the country could be higher than the current findings of this study. Examples of these species include, Amaranthus graecizans and Amaranthus viridis from the Amaranthaceae family, which were used in the past by Bedouin people of UAE to treat scorpion stings, snake bites and itchy skin rashes as reported by Sakkir et al., [28].

According to published research by Shahin et al., [4], the essential oil of the indigenous medicinal Cleome amblyocarpa was extracted and studied for the first time, declaring positive 
antioxidant activities. Recently, another study extracted essential oil from the seeds of Moringa peregrina and evaluated its chemical composition and antioxidant potentials [8]. Therefore, it is expected that similar results can be found while studying other medicinal and aromatic indigenous species.

\subsection{List of Abbreviations}

This section provided the meaning and description of all the abbreviations that were used to construct the tables of the UAE (native and naturalized) EO-bearing plants (Tables 2-10).

- Botanical Name: Syn. "Synonyms"; Eng. "English"; Arb. "Arabic".

- Form: Vine "V"; Grass "G"; Weed "W"; Forb "F"; Herb "H"; Shrub "S"; Tree "T".

- Life Form: Geophyte "Ge"; Phanerophyte "Ph"; Chamaephyte "Ch"; Hemicryptophyte "He"; Therophyte "Th"; Cryptophyte "Cr"; Neophyte "Na".

- Life Cycle: Annual "A"; Biennial "B"; Perennial "P".

- Economic Value: Medicine and/or Folk Medicine "Med"; Food "Fod"; Nutrition "Nutr"; Food Preservation "FPre"; Flavoring "Flav"; Food Aroma "FArom"; Forage "Forg"; Aromatic "Arom"; Essential Oils "EOs"; Cosmetic "Cosm"; Biofuel "Biof"; Fuel "Fuel"; Cleaning and Hygiene "Clea"; Insecticides "Insec"; Ecological "Eco"; Landscaping "Lands"; Other "Oth": (Dye, Constructions, Household items, Cushions, Fibers, Sponges, Tobacco, Honey Production, Soil Amendment).

- Folk Medicine:

(Application: yes "+", no ".") (Country: Applications examples + Plant parts)

Plants' part abbreviations: Leaves "L"; Stems and twigs "St"; Pods "Pd"; Buds "Bd"; Bark "Bk"; Flowers "Fl"; Shoots and Aerial parts "Sh"; Fruits "Fr"; Seeds "Se"; Whole Plant "W").

- Emirates: Abu Dhabi "AD"; Dubai "Du"; Sharjah "S"; Fujairah "F"; Ajman "A"; Ras Al Khaimah "RAK"; Umm Al Quwain "UAQ".

- Important Locations: Al Ain "Ain"; Khor Kalba "K"; Khor Fakkan "KF"; Hajar Mountains "HM"; Ru'us Al-Jibal "RA"; Jebel Hafit "JH"; Wadi Jeema"J"; Hatta "H"; Wadi Lakayyam "WL"; Along the Country "AC"; Country Center "CC"; East Emirates "EE"; North Emirates "NE"; Coasts of North Emirates "CN"; Eastern Coast "EC"; Western coast "WC"; Scattered Locations "SL"

- Soil: Sand "San"; Silt "Sil"; Rocky or Gravel "Roc"; Saline "Sal".

- Habitats: Oasis "Oas"; Sand Dunes "Dun"; Coasts "Cos"; Roadsides "Rod"; Offshore Islands "Off"; Inland Water Habitats "Wat"; Plantations and Farmlands and Irrigated Lands "Plat"; Hillsides "Hil"; Disturbed Sites "DS"; Alluvial and Interdunal Plains "Apl"; Wadis "Wad"; Gardens "Gar"; Fallow Fields and Plains "FF"; Cliffs "Cli"; Mountains and Rocky terrains "Mou"; Plateaux "PX"; Wastelands and Abandoned Fields "AF"; Urban areas "Urb".

- Flowering: Months' abbreviations will be used.

- Wildlife Status: Fairly common and locally abundant "FC"; Common and widespread locally "CO"; Not common "NC"; Rare and vulnerable "RA"; Not evaluated "NE"; Cultivated Plant " $\mathrm{C}$ ".

- Plant Part: Potential for EOs (Roots "R"; Rhizomes "Rz"; Tuber "Tu"; Leaves "L"; Stems and twigs "St"; Pods "Pd"; Buds "Bd"; Bulbs "Bl"; Bark "Bk"; Flowers "Fl"; inflorescences "IF"; Shoots and Aerial parts "Sh"; Fruits "Fr"; Seeds "Se"; Whole Plant “W").

- Physical Properties: EOs physical characteristics (Color/Odor) Plant part + extraction method.

- $\quad$ Yield (\%): EO yield (\%, $v / w$ of dry weight). Supported with plant part and extraction method

- Isolation Method: EO extraction method including: 
Hydrodistillation "HD"; Steam Distillation "SD"; Dry Steam Distillation "DSD"; Microdistillation "MD"; Solid-Phase Microextraction "SPM"; Simultaneous Steam Distillation and Extraction "SDE"; Vacuum Distillation "VD"; Ligarine Extraction "LE"; Soxhelt Extraction "SH"; Headspace Analysis "H"; Gas Chromatography Flame Ionization Detector "GC-FID"; Supercritical CO2 Fluid Extraction "SFE"; Microwave-Assisted Hydrodistillation "MW"; Solvent-Free Microwave Extraction "SFME"; Tenax-Trapping "TT".

- Main Chemical Groups/Components:

(Main EOs Chemical Groups) and/or (Main/Potential Chemical Constituents) Plant part + extraction method.

- Biological Activity: [EO Biological Activity] (Activity Details) Plant part + extraction method.

Antitumor "AT"; Antioxidant "AO"; Antifungal "AF"; Antibacterial "AB"; Antimicrobial "AM"; Antibiotic "OT"; Anti-inflammatory "AI"; Antianxiety "AA"; Mosquito Attractant/Repellent "MR"; Insecticidal and Pesticidal Activity "IS"; Larvicidal Activity "LA"; Nematicidal activity "NM"; Oviposition attractant/deterrent activity "OA"; Antihelminthic "Anthelmintic" effect "AH"; Antiechinococcal Activity "AE"; Fumigant Toxicity "FT"; Antidiabetic Activity "AD"; Antistreptococcal "AS"; Anticarcinogenic Effect "AC"; Cytotoxic Properties "CP"; Antimycotoxins "XN"; Phytotoxic Properties and Herbicidal Activity "PP"; Apoptotic Properties "AP"; Antimutagenic Properties "MP"; Analgesic properties "GP"; Antidepressant "DP"; Antispasmodics properties "ASP"; Antinociceptive activity "AN"; Antinociceptive Activity "CE"; Antiseptic "SP"; Stimulant "ST"; Antidiarrheal Activity "DR".

- General Notes: The use of "!" means information uncertainty.

\subsection{Phytochemicals and Biological Activities from UAE Based Plants}

Reviewing the literature, essential oils of the following six native/naturalized UAE plants were investigated under UAE climatic conditions, including Pulicaria glutinosa (Asteraceae) [7], Cleome amblyocarpa (Cleomaceae) [4], Mentha spicata (Lamiaceae) [130], Teucrium stocksianum (Lamiaceae) [6], Haplophyllum tuberculatum (Rutaceae) [5] and Moringa peregrine (Moringaceae) [8], with rich therapeutic applications for the last five species in folk medicine generally and the UAE traditional practices specifically. For example, infusion of C. amblyocarpa leaves was used to treat abdominal and rheumatic pain. M. spicata was used to promote general health-care benefits. Meanwhile, T. stocksianum has various applications related to kidney, stomach pains, thyroid problems and the common cold. The leaves of $H$. tuberculatum were used to treat scorpion stings, eaten as sedative and crushed in water and drunk to treat painful joints. In the UAE folk practices, the seeds' oil of $M$. peregrine has been taken orally for constipation and stomach cramp, and the seeds' oil mixture with clove oil and cardamom oil has been taken as a drink during labor. Besides, the seeds oily extract is used to treat headaches, fever, muscle pains, burns, abdominal pain and constipation. M. peregrine leaves' extract can be rubbed on skin to treat a skin rash [22].

The rocky soils of the Hajar mountain are among the most famous places for P. glutinosa, T. stocksianum, H. tuberculatum and M. peregrine, including Khor Fakkan and Ru'us Al-Jibal for T. stocksianum and M. peregrine. While the sandy soils of the North Emirates of Dubai, Sharjah, Ajman and Umm Al Quwain are rich in C. amblyocarpa, the mountains, hillsides and wadis of Fujairah, Ras Al Khaimah, Sharjah and Abu Dhabi are rich places for H. tuberculatum [21]. The mint herb M. spicata is widely cultivated in farms for food production purposes, and contributes to the richest essential oils yield which is $10.90 \%$, extracted from shoots using Supercritical carbon dioxide $\left(\mathrm{SCCO}_{2}\right)$ (Press: 350 bar, Temp: 50 ${ }^{\circ} \mathrm{C}$ ) [130]. While the essential oil average yields of the aerial parts of each of P. glutinosa, T. stocksianum, $H$. tuberculatum and C. amblyocarpa, were (according to the highest yield reported in the literature based on UAE) 0.5 [7], 0.34 [6], 0.04 [5] and $0.0266 \%$ [4], respectively. The essential oil seeds' oil of $M$. peregrine extracted by hydrodistillation reported to be $0.22 \%$ [8].

A study of the phytochemicals showed that the major constituents of P. glutinosa essential oils extracted from aerial parts (including flowers) by steam distillation were 
$p$-elemene, 7-cadinol and $a$-cadinol (Sesquiterpenes) [7]. No studies were found to test the biological activities of the essential oil extracts for this shrub.

According to Shahin et al., [4], the major phytochemicals found for C. amblyocarpa essential oil (extracted by hydrodistillation from the whole herb) were isobornyl formate, tetrahydro-linalool acetate, neo-menthyl acetate, 1-dodecene and $\gamma$-elemene. The extract showed antioxidant activities (in vitro) using DPPH, FRAP and ABTS assays.

As reported by Al-Marzouqi et al., [130], the main chemical composition of $M$. spicata leaves' essential oil (extracted by $\mathrm{SCCO}_{2}$ ) included carvone, $a$-pinene, limonene and linalool, which were significantly higher in the locally cultivated $M$. spicata in comparison to herbs imported from France, Syria and India. Although many studies in the literature reported the various biological activities of M. spicata (e.g., antibacterial, antifungal, antimicrobial, antioxidant, insecticidal and pesticidal, larvicidal activity, mosquito attractant/repellent and antimutagenic properties), however, no studies thus far have tested the biological activity of the oil for the herb cultivated under UAE climatic conditions.

According to Al Yousuf et al. [6], the oil of the aerial parts of T. stocksianum, collected from the UAE, was characterized by $a$-cadinol and 6-cadinene. Studies based on other countries reported the antinociceptive activity of the oil, with no studies found related to the biological activity of the oil based on the UAE.

Based on the research findings of Al Yousuf et al., [5], the oil extracted from the aerial parts of $H$. tuberculatum $\alpha$-phellandrene (10.7-32.9\%) being the major component and with significant amounts of other phytochemicals varied in existence and percentages according to the harvesting season. Such phytochemicals include $\beta$-caryophyllene, $\beta$-pinene, limonene, $\delta$-3-carene, linalool, linalyl acetate, $\beta$-caryophyllene and $\alpha$-terpineol. The biological studies related to $H$. tuberculatum carried out based on other countries reported that the oil exhibits various biological activities including antifungal, antibacterial, antimicrobial, mosquito attractant/repellent, insecticidal and pesticidal activity and larvicidal activity. On the other hand, no studies have been conducted yet to test these activities and others for the essential oil of this perennial herb grown under the UAE climate.

According to Senthilkumar et al. [8], the seeds' oil of M. peregrine was characterized by the availability of geijerene $(33.38 \%)$, linalool $(23.36 \%)$, caryophyllene oxide $(19.28 \%)$, n-hexadecane $(12.59 \%)$ and carvacrol. The oil was found to be a potential alternative choice to the synthetic antioxidants, having radical scavenging activities including; $\mathrm{DPPH}^{\bullet}$ radical $\left(\mathrm{IC}_{50}=37.70 \mu \mathrm{g} / \mathrm{mL}\right), \mathrm{ABTS}^{\bullet+}$ radical $\left(\mathrm{IC}_{50}=34.03 \mu \mathrm{g} / \mathrm{mL}\right)$, superoxide anion $\left(\mathrm{IC}_{50}=36.57 \mu \mathrm{g} / \mathrm{mL}\right)$, nitric oxide radical $\left(\mathrm{IC}_{50}=29.15 \mu \mathrm{g} / \mathrm{mL}\right)$, hydrogen peroxide $\left(\mathrm{IC}_{50}=43.93 \mu \mathrm{g} / \mathrm{mL}\right)$ and hydroxyl radical $\left(\mathrm{IC}_{50}=29.99 \mu \mathrm{g} / \mathrm{mL}\right)$.

Studies of phytochemicals and biological studies provide scientific justification for the rich therapeutic applications of the previously mentioned native/naturalized plants in the UAE traditional practices. At the same time, it is obvious that there is a lack of essential oil studies based on the UAE, and more efforts are needed to investigate the phytochemicals and biological activities of oils extracted from locally grown and harvested native plants. Besides, comparative studies to compare the essential oil yield (quantitatively and qualitatively) for plants grown in the UAE and other countries are required. This is needed to highlight the native/naturalized plants of superior quality and biological activity, and utilize the same (after standardization) for commercial purposes in various industries (e.g., pharmaceuticals, cosmetics, food preservatives, fragrance and flavor industries).

\section{Obstacles and Difficulties}

The greatest obstacles and difficulties that were faced are related to the scarcity of the references to UAE wildflowers (Shahin, 2018c). There is so much confusion in the literature between the botanical names and the synonyms, including spelling mistakes that make the task of data collection to list all the Emirati plants (followed by screening and listing the Emirati EO-bearing plants) a difficult and complicated mission.

For example, Cornulaca arabica Botsch and Cornulaca monacantha Delile were mentioned as two different species in the reference of Brown and Sakkir [22], while according 
to published study [21] Cornulaca arabica Botsch is a synonym of Cornulaca monacantha Delile. Besides, the plants Actiniopteris semiflabellata, Commicarpus boissieri and Cymbopogon jwarancusa were mentioned with minor spelling mistakes as Actioniopteris semiflabellata, Commicarpus boisieri and Cymbopogon jwarancuse, (respectively) in the textbook of Jongbloed et al., [21] which is one of the most important references of the UAE indigenous and naturalized plants.

Moreover, some publications use either the synonyms or the common names instead of using the botanical names. Therefore, while reviewing the literature using the formal botanical names (to screen the EO potential) no results will appear, although, in many cases the plant would be a rich resource of EO phytochemicals. For example, some publications will use Dipcadi serotinum, Cymbopogon parkeri Stapf. Heliotropium europaeum and Calligonum polygonoides instead of using the botanical names, which are Dipcadi erythraeum Webb and Berth., Cymbopogon commutatus (Steud.) Stapf., Heliotropium lasiocarpum and Calligonum comosum, respectively.

\section{Conclusions and Future Perspectives}

Based on our comprehensive and detailed screening of all the families of the UAE wildflowers, we concluded that there are at least 137 EO-bearing plants in the UAE (17\% of the UAE wildflowers) belonging to 46 families. The top three richest families, based on the number of their species, are Asteraceae, Fabaceae and Lamiaceae.

Most of the UAE EO-bearing plants have rich traditional medicinal applications and other economic values, such as pharmaceuticals, nutrition, aromatherapy, fragrance and flavoring. Generally, the shoots (especially leaves and flowers) are the most important parts to extract EO phytochemicals (e.g., terpenoids) of valuable biological activities, such as antioxidant, antimicrobial and antitumor properties.

The UAE EO-bearing plants are widespread in the areas of plantations, mountains and wadis of the country. Serious efforts to educate landlords about the great value of the UAE EO-bearing plants are needed, to make sure that these expensive species are well-cultivated in a sustainable manner. Besides, strong efforts related to management and strategic planning should be employed to conserve the natural habitats of the EO-bearing plants.

All our obtained results support that the UAE is a rich natural resource for the native and naturalized EO-bearing plants that have rich ethnobotanical applications of multiple economic potential.

Therefore, serious efforts are needed to standardize the oil yield (quantitatively and qualitatively) for all listed essential oil-bearing plants of the UAE, and to focus sustainability on native essential oil-bearing plants of industrial applications at research and commercialization level. Taking into consideration that this field is promising for multiple research disciplines and discoveries.

Author Contributions: Conceptualization and methodology, S.M.S.; validation, A.J. and M.A.M.A.; writing-original draft preparation, S.M.S.; writing—review and editing, A.J.; supervision, M.A.M.A. and A.J.; funding acquisition, M.A.M.A. All authors have read and agreed to the published version of the manuscript.

Funding: This research was funded by UAEU fund No. 31F029, (Ph.D. research grant).

Acknowledgments: We express our appreciation to David Allen from the International Union for Conservation of Nature (IUCN) for providing references related to UAE native plants. We are also thankful for the Ministry of Climate Change and Environment (MOCCAE)-UAE, for the invitation to participate in the Red List National Meeting (15-19 September 2019) and the possibility to exchange knowledge with knowledgeable researchers in the field of native plants (e.g., Gary R. Feulner, Ali El-Keblawy, and members of Sharjah Seed Bank). The support from Shyam S. Kurup, Department of Integrative Agriculture, CAVM, UAEU is gratefully acknowledged. In addition, many thanks to Al Foah Research Farm (Especially Arshed El Daly)—United Arab Emirates University (UAEU) for sharing knowledge related to native plants. Furthermore, we would like to thank Rahaf Ajaj (Abu Dhabi University) for her assistance in proofreading. This research was supported by the UAEU, College of Food and Agriculture, fund No. 31F029. 
Conflicts of Interest: The authors declare no conflict of interest.

\section{References}

1. Baser, K.H.C.; Buchbauer, G. Handbook of Essential Oils: Science, Technology, and Applications; CRC Press: Boca Raton, FL, USA, 2015.

2. Bakkali, F.; Averbeck, S.; Averbeck, D.; Idaomar, M. Biological effects of essential oils-A review. Food Chem. Toxicol. 2008, 46, 446-475. [CrossRef]

3. Shahin, S.M.; Salem, M.A. The innovative perspective of arid land agriculture: Essential oil-bearing plants as factories for a healthy and sustainable future. In Proceedings of the The Annual Meeting of Crop Science Society of America (CSSA), Synergy in Science: Partnering for Solutions, Minneapolis, MN, USA, 15-18 November 2015; ACSESS Digital Library: Hoboken, NJ, USA, 2015.

4. Shahin, S.M.; Kurup, S.; Cheruth, J.; Salem, M. Chemical composition of Cleome amblyocarpa Barr. \& Murb. essential oil under different irrigation levels in sandy soils with antioxidant activity. J. Essent. Oil Bear. Plants 2018, 21, 1235-1256.

5. Al Yousuf, M.H.; Bashir, A.K.; Veres, K.; Dobos, Á.; Nagy, G.; Máthé, I.; Blunden, G.; Vera, J.R. Essential oil of Haplophyllum tuberculatum (Forssk.) A. Juss. from the United Arab Emirates. J. Essent. Oil Res. 2005, 17, 519-521. [CrossRef]

6. Al Yousuf, M.H.; Bashir, A.K.; Dobos, Á.; Veres, K.; Nagy, G.; Máthé, I.; Blunden, G. The composition of the essential oil of Teucrium stocksianum from the United Arab Emirates. J. Essent. Oil Res. 2002, 14, 47-48. [CrossRef]

7. Al Yousuf, M.; Bashir, A.; Veres, K.; Dobos, A.; Nagy, G.; Mathe, I.; Blunden, G. Essential oil of Pulicaria glutinosa Jaub. from the United Arab Emirates. J. Essent. Oil Res. 2001, 13, 454-455. [CrossRef]

8. Senthilkumar, A.; Thangamani, A.; Karthishwaran, K.; Cheruth, A.J. Essential oil from the seeds of Moringa peregrina: Chemical composition and antioxidant potential. South Afr. J. Bot. 2020, 129, 100-105. [CrossRef]

9. Ajaj, R.; Shahin, S.; Salem, M. The challenges of climate change and food security in the United Arab Emirates (UAE): From deep understanding to quick actions. J. Curr. Nutr. Food Sci. 2018, 14, 1-8. [CrossRef]

10. Shahin, S.M.; Salem, M.A. Review future concerns on Irrigation requirements of date palm tree in the United Arab Emirates (UAE): Call for quick actions. In Proceedings of the 5th International Date Palm Conference, Abu Dhabi, United Arab Emirates, 16-18 March 2014; pp. 255-262, ISBN 978-9948-22-868-4.

11. Ajaj, R.; Shahin, S.; Kurup, S.; Cheruth, J.; Salem, M.A. Elemental fingerprint of agriculture soils of eastern region of the Arabian desert by ICP-OES with GIS mapping. J. Curr. Environ. Eng. 2018, 5, 1-23. [CrossRef]

12. Shahin, S.M.; Salem, M.A. The challenges of water scarcity and the future of food security in the United Arab Emirates (UAE). Nat. Res. Cons. 2015, 3, 1-6. [CrossRef]

13. Mohamed, M.; Murad, A.; Chowdhury, R. Evaluation of groundwater quality in the eastern district of Abu Dhabi Emirate: UAE. Bull. Environ. Contam. Toxicol. 2017, 98, 385-391. [CrossRef]

14. Batanouny, K.H. Current knowledge of plant ecology in the Arab Gulf countries. Catena 1987, 14, 291-315. [CrossRef]

15. Western, R.A. The Flora of the United Arab Emirates: An Introduction; United Arab Emirates University Publications: Al Ain, United Arab Emirates, 1989.

16. Tanira, M.O.M.; Bashir, A.K.; Dib, R.; Goodwin, C.S.; Wasfi, I.A.; Banna, N.R. Antimicrobial and phytochemical screening of medicinal plants of the United Arab Emirates. J. Ethnopharmacol. 1994, 41, 201-205. [CrossRef]

17. Wasfi, I.A.; Bashir, A.K.; Abdalla, A.A.; Banna, N.R.; Tanira, M.O.M. Antiinflammatory activity of some medicinal plants of the United Arab Emirates. J. Ethnopharmacol. 1995, 33, 124-128. [CrossRef]

18. Karim, F.M. Weeds in the United Arab Emirates; United Arab Emirates University Publications: Al Ain, United Arab Emirates, 1995.

19. Emirates Natural History Group. Tribulus: Bulletin of the Emirates Natural History Group; AI lttihad Press and Printing Corporation: Abu Dhabi, United Arab Emirates, 1997; Volume 7, pp. 1-32.

20. Böer, B.; Chaudhary, S.A. New Records for the Flora of the United Arab Emirates. Willdenowia 1999, 29, 159-165. [CrossRef]

21. Jongbloed, M.; Feulner, G.; Böer, B.; Western, A.R. The Comprehensive Guide to the Wild Flowers of the United Arab Emirates; Environmental Research and Wildlife Development Agency: Abu Dhabi, United Arab Emirates, 2003.

22. Brown, G.; Sakkir, S. The Vascular Plants of Abu Dhabi Emirate; Environmental Research and Wildlife Development Agency: Abu Dhabi, United Arab Emirates, 2004.

23. Aspinall, S. The Emirates: A Natural History; Trident Press Ltd.: Abu Dhabi, United Arab Emirates, 2005.

24. ZCHRTM (Zayed complex for Herbal Research and Traditional Medicine). In Encyclopedia of Medicinal Plants of UAE; General Authority for Health Services for the Emirate of Abu Dhabi: Abu Dhabi, United Arab Emirates, 2005 ; Volume 1.

25. Handa, S.S.; Rakesh, D.D.; Vasisht, K. Compendium of Medicinal and Aromatic Plants: Asia. ICS UNIDO Asia $2006,2,305$.

26. Karim, F.M.; Dakheel, A.J. Salt-Tolerant Plants of the United Arab Emirates; FAO: Rome, Italy, 2006.

27. Mousa, M.; Fawzi, N. Vegetation analysis of Wadi Al Ain, United Arab Emirates. Acad. J. Plant Sci. 2009, 2, 9-15.

28. Sakkir, S.; Kabshawi, M.; Mehairbi, M. Medicinal plants diversity and their conservation status in the United Arab Emirates (UAE). J. Med. Plant Res. 2012, 6, 1304-1322.

29. Fawzi, N.; Ksiksi, T. Plant species diversity within an important United Arab Emirates ecosystem. Rev. Écol. 2013, 67, 25-36.

30. Hurriez, S.H. Folklore and Folklife in the United Arab Emirates; Routledge: New York, NY, USA, 2013.

31. Feulner, G.R. The Olive Highlands: A unique" island" of biodiversity within the Hajar Mountains of the United Arab Emirates. Tribulus 2014, 22, 9-35.

32. El-Keblawy, A.A.; Khedr, A.H.A.; Khafaga, T.A. Mountainous Landscape Vegetation and Species Composition at Wadi Helo: A Protected area in Hajar Mountains, UAE. Arid Land Res. Manag. 2016, 30, 389-399. [CrossRef] 
33. EAD (Environmental Agency of Abu Dhabi). Jewels of the UAE. 2017. Available online: http://www.arkive.org/uae/en/plantsand-algae (accessed on 1 April 2018).

34. EAD (Environmental Agency of Abu Dhabi). Grasses, Sedges and Rushes of the UAE; EAD (Environmental Agency of Abu Dhabi): Abu Dhabi, United Arab Emirates, 2019.

35. Magwa, M.L.; Gundidza, M.; Gweru, N.; Humphrey, G. Chemical composition and biological activities of essential oil from the leaves of Sesuvium portulacastrum. J. Ethnopharmacol. 2006, 103, 85-89. [CrossRef]

36. Srivastav, S.; Singh, P.; Mishra, G.; Jha, K.K.; Khosa, R.L. Achyranthes aspera-An important medicinal plant: A review. J. Nat. Prod. Plant Res. 2011, 1, 1-14.

37. Samejo, M.Q.; Memon, S.; Bhanger, M.I.; Khan, K.M. Chemical compositions of the essential oil of Aerva javanica leaves and stems. Pak. J. Anal. Environ. Chem. 2012, 13, 48-52.

38. Samejo, M.Q.; Memon, S.; Bhanger, M.I.; Khan, K.M. Comparison of chemical composition of Aerva javanica seed essential oils obtained by different extraction methods. Pak. J. Pharm. Sci. 2013, 26, 757-760. [PubMed]

39. Khomarlou, N.; Aberoomand-Azar, P.; Lashgari, A.P.; Tebyanian, H.; Hakakian, A.; Ranjbar, R.; Ayatollahi, S.A. Essential oil composition and in vitro antibacterial activity of Chenopodium album subsp. striatum. Acta Biol. Hung. 2018, 69, 144-155. [CrossRef]

40. Taghizadeh, S.F.; Davarynejad, G.; Asili, J.; Riahi-Zanjani, B.; Nemati, S.H.; Karimi, G. Chemical composition, antibacterial, antioxidant and cytotoxic evaluation of the essential oil from pistachio (Pistacia khinjuk) hull. Microb. Pathog. 2018, $124,76-81$. [CrossRef]

41. Al-Snafi, A.E. Chemical constituents and pharmacological activities of Ammi majus and Ammi visnaga. A review. Int. J. Pharm. Ind. Res. 2013, 3, 257-265.

42. Kazemi, M. Phenolic profile, antioxidant capacity and anti-inflammatory activity of Anethum graveolens L. essential oil. Nat. Prod. Res. 2015, 29, 551-553. [CrossRef]

43. Shahabipour, S.; Firuzi, O.; Asadollahi, M.; Faghihmirzaei, E.; Javidnia, K. Essential oil composition and cytotoxic activity of Ducrosia anethifolia and Ducrosia flabellifolia from Iran. J. Essent. Oil Res. 2013, 25, 160-163. [CrossRef]

44. Oran, S.A.; Al-Eisawi, D.M. Medicinal plants in the high mountains of northern Jordan. Int. J. Biodiv. Cons. $2014,6,436-443$.

45. Askari, F.; Sefidkon, F.; Teymouri, M.; Yousef, N. Chemical composition and antimicrobial activity of the essential oil of Pimpinella puberula (DC.) Boiss. J. Agr. Sci. Tech. 2009, 11, 431-438.

46. Radulović, N.S.; Mladenović, M.Z.; Stojanović-Radić, Z.Z. Synthesis of small libraries of natural products: New esters of long-chain alcohols from the essential oil of Scandix pecten-veneris L. (Apiaceae). Flavour Fragr. J. 2014, 29, 255-266. [CrossRef]

47. Saeed, N.; Khan, M.R.; Shabbir, M. Antioxidant activity, total phenolic and total flavonoid contents of whole plant extracts Torilis leptophylla L. BMC Complement. Altern. Med. 2012, 12, 221. [CrossRef]

48. Derwich, E.; Benziane, Z.; Boukir, A. Antibacterial activity and chemical composition of the essential oil from flowers of Nerium oleander. Electron. J. Environ. Agric. Food Chem. 2010, 9, 1074-1084.

49. Lawal, O.A.; Ogunwande, I.A.; Opoku, A.R. Chemical composition of essential oils of Plumeria rubra L. grown in Nigeria. Eur. J. Med. Plants. 2015, 6, 55-61. [CrossRef]

50. Al-Rowaily, S.L.; Abd-ElGawad, A.M.; Assaeed, A.M.; Elgamal, A.M.; Gendy, A.E.N.G.E.; Mohamed, T.A.; Dar, B.A.; Mohamed, T.K.; Elshamy, A.I. Essential Oil of Calotropis procera: Comparative Chemical Profiles, Antimicrobial Activity, and Allelopathic Potential on Weeds. Molecules 2020, 25, 5203. [CrossRef]

51. Atghaei, M.; Sefidkon, F.; Darini, A.; Sadeghzadeh Hemayati, S.; Abdossi, V. Essential Oil Content and Composition of the Spathe in Some Date Palm (Phoenix dactylifera L.) Varieties in Iran. J. Essent. Oil Bear. Plants 2020, 23, 292-300. [CrossRef]

52. Zebarjad, Z.; Farjam, M.H. Evaluation of antimicrobial activity of essential oils from different parts of Anthemis odontostephana Boiss. Var. odontostephana. Int. J. Pharm. Phytochem. Res. 2015, 7, 579-584.

53. Tabari, M.A.; Youssefi, M.R.; Benelli, G. Eco-friendly control of the poultry red mite, Dermanyssus gallinae (Dermanyssidae), using the $\alpha$-thujone-rich essential oil of Artemisia sieberi (Asteraceae): Toxic and repellent potential. Parasitol. Res. 2017, 116, 1545-1551. [CrossRef]

54. Ercetin, T.; Senol, F.S.; Orhan, I.E.; Toker, G. Comparative assessment of antioxidant and cholinesterase inhibitory properties of the marigold extracts from Calendula arvensis L. and Calendula officinalis L. Ind. Crops Prod. 2012, 36, 203-208. [CrossRef]

55. Haghi, G.; Arshi, R.; Ghazian, F.; Hosseini, H. Chemical composition of essential oil of aerial parts of Cichorium intybus L. from Iran. J. Essent. Oil Bear. Plants 2012, 15, 213-216. [CrossRef]

56. Cheng, X.R.; Thabit, R.A.; Wang, W.; Shi, H.W.; Shi, Y.H.; Le, G.W. Analysis and comparison of the essential oil in Conyza bonariensis grown in Yemen and China. Prog. Mod. Biomed. 2013, 36, 7034-7038.

57. Chang, K.M.; Kim, G.H. Constituents of the Essential Oil from Eclipta prostrata L. Prev. Nutr. Food Sci. 2009, 14, 168-171. [CrossRef]

58. Rustaiyan, A.; Azar, P.A.; Moradalizadeh, M.; Masoudi, S.; Ameri, N. Volatile constituents of three compositae herbs: Anthemis altissima L. var. altissima Conyza Canadensis (L.) Cronq. and Grantina aucheri Boiss. Growing Wild in Iran. J. Essen. Oil Res. 2004, 16, 579-581. [CrossRef]

59. Al-Mahrezi, J.A.; Al-Sabahi, J.N.; Akhtar, M.S.; Selim, D.; Weli, A.M. Essential oil composition and antimicrobial screening of Launaea nudicaulis grown in Oman. Int. J Pharm. Sci. Res. 2011, 2, 3166.

60. Saleem, M.; Parveen, S.; Riaz, N.; Tahir, M.N.; Ashraf, M.; Afzal, I.; Jabbar, A. New bioactive natural products from Launaea nudicaulis. Phytochem. Lett. 2012, 5, 793-799. [CrossRef] 
61. Siddiqui, N.A. Chemical constituents of essential oil from flowers of Matricaria aurea grown in Saudi Arabia. Indian J. Drugs 2014, 2, 164-168.

62. Karam, T.K.; Ortega, S.; Nakamura, T.U.; Auzély-Velty, R.; Nakamura, C.V. Development of chitosan nanocapsules containing essential oil of Matricaria chamomilla L. for the treatment of cutaneous leishmaniasis. Int. J. Biol. Macromol. 2020, 162, 199-208. [CrossRef]

63. Amin, A.; Mousa, M. Merits of anti-cancer plants from the Arabian Gulf region. Can. Ther. 2007, 5, 55-66.

64. Suliman, F.E.O.; Fatope, M.O.; Al-Saidi, S.H.; Al-Kindy, S.M.; Marwah, R.G. Composition and antimicrobial activity of the essential oil of Pluchea arabica from Oman. Flavour Fragr. J. 2006, 21, 469-471. [CrossRef]

65. El-Ghorab, A.H.; Ramadan, M.M.; El-Moez, S.I.A.; Soliman, A.M.M. Essential oil, antioxidant, antimicrobial and anticancer activities of Egyptian Pluchea dioscoridis extract. Res. J. Pharm. Biol. Chem. Sci. 2015, 6, 1255-1265.

66. Goyal, P.K.; Aggarwal, R.R. A Review on Phytochemical and biological investigation of plant genus Pluchea. Indo Am. J. Pharm. Res. 2013, 3, 3000-3007.

67. Demirci, B.; Baser, K.H.; Duman, H. The essential oil composition of Gnaphalium luteo-album. Chem. Nat. Comp. 2009, 45, 446-447. [CrossRef]

68. Djermane, N.; Gherraf, N.; Arhad, R.; Zellagui, A.; Rebbas, K. Chemical composition, antioxidant and antimicrobial activities of the essential oil of Pulicaria arabica (L.) Cass. Pharm. Lett. 2016, 8, 1-6.

69. Al-Hajj, N.Q.M.; Wang, H.; Gasmalla, M.A.; Ma, C.; Thabit, R.; Rahman, M.R.T.; Tang, Y. Chemical composition and antioxidant activity of the essential oil of Pulicaria inuloides. J. Food Nut. Res. 2014, 2, 221-227. [CrossRef]

70. Al-Hajj, N.Q.M.; Ma, C.; Thabit, R.; Gasmalla, M.A.; Musa, A.; Aboshora, W.; Wang, H. Chemical composition of essential oil and mineral contents of Pulicaria inuloides. J. Acad. Ind. Res. 2014, 2, 675-678.

71. Al-Hajj, N.Q.M.; Algabr, M.N.; Omar, K.A.; Wang, H. Anticancer, Antimicrobial and Antioxidant Activities of the Essential Oils of Some Aromatic Medicinal Plants (Pulicaria inuloides-Asteraceae). J. Food Nutr. Res. 2017, 5, 490-495. [CrossRef]

72. Boumaraf, M.; Mekkiou, R.; Benyahia, S.; Chalchat, J.C.; Chalard, P.; Benayache, F.; Benayache, S. Essential oil composition of Pulicaria undulata (L.) DC. (Asteraceae) growing in Algeria. Int. J. Pharmacogn. Phytochem. Res. 2016, 8, 746-749.

73. Demirci, B.; Yusufoglu, H.S.; Tabanca, N.; Temel, H.E.; Bernier, U.R.; Agramonte, N.M.; Alqasoumi, S.I.; Al-Rehaily, A.J.; Başer, K.H.C.; Demirci, F. Rhanterium epapposum Oliv. essential oil: Chemical composition and antimicrobial, insect-repellent and anticholinesterase activities. Saudi Pharm. J. 2017, 25, 703-708. [CrossRef] [PubMed]

74. Basaid, K.; Bouharroud, R.; Furze, J.N.; Benjlil, H.; de Oliveira, A.L.; Chebli, B. Biopesticidal value of Senecio glaucus subsp. coronopifolius essential oil against pathogenic fungi, nematodes, and mites. Mater. Today Proc. 2020, 27, 3082-3090. [CrossRef]

75. Belhattab, R.; Amor, L.; Barroso, J.G.; Pedro, L.G.; Figueiredo, A.C. Essential oil from Artemisia herba-alba Asso grown wild in Algeria: Variability assessment and comparison with an updated literature survey. Arab. J. Chem. 2014, 7, 243-251. [CrossRef]

76. Mokhtar, M.M.; Shaban, H.M.; Hegazy, M.E.A.F.; Ali, S.S. Evaluating the potential cancer chemopreventive efficacy of two different solvent extracts of Seriphidium herba-alba in vitro. Bull. Fac. Pharm. Cairo Univ. 2017, 55, 195-201. [CrossRef]

77. Verma, R.S.; Padalia, R.C.; Chauhan, A.; Sundaresan, V. Essential oil composition of Sphagneticola trilobata (L.) Pruski from India. J. Essent. Oil Res. 2014, 26, 29-33. [CrossRef]

78. Padin, S.B.; Fuse, C.; Urrutia, M.I.; Dal Bello, G.M. Toxicity and repellency of nine medicinal plants against Tribolium castaneum in stored wheat. Bull. Insectol. 2013, 66, 45-49.

79. Al-Mazroa, S.A.; Al-Wahaibi, L.H.; Mousa, A.A.; Al-Khathlan, H.Z. Essential oil of some seasonal flowering plants grown in Saudi Arabia. Arab. J. Chem. 2015, 8, 212-217. [CrossRef]

80. Saeedi, M.; Morteza-Semnani, K. Chemical composition and antimicrobial activity of the essential oil of Heliotropium europaeum. Chem. Nat. Comp. 2009, 45, 98-99. [CrossRef]

81. Ahmed, S.; Ibrahim, M.; Khalid, K. Investigation of essential oil constituents isolated from Trichodesma africanum (L.) grow wild in Egypt. Res. J. Med. Plant 2015, 9, 248-251. [CrossRef]

82. Kamali, H.; Sani, T.A.; Feyzi, P.; Mohammadi, A. Chemical composition and antioxidant activity from essential oil of Capsella bursa-pastoris. Int. J. Pharmtech. Res. 2015, 8, 1-4.

83. Mohammadzadeh Moghaddam, M.; Elhamirad, A.H.; Shariatifar, N.; Saidee Asl, M.R.; Armin, M. Anti-bacterial effects of essential oil of Cardaria draba against bacterial food borne pathogens. Horizon Med. Sci. 2014, 19, 9-16.

84. Prabhakar, K.R.; Srinivasan, K.K.; Rao, P.G. Chemical investigation, anti-inflammatory and wound healing properties of Coronopus didymus. Pharm. Boil. 2002, 40, 490-493. [CrossRef]

85. Mahmoud, A.W.M.; Taha, S.S. Main sulphur content in essential oil of Eruca Sativa as affected by nano iron and nano zinc mixed with organic manure. Agriculture 2018, 64, 65-79. [CrossRef]

86. El-Shabasy, A. Survey on medicinal plants in the flora of Jizan Region, Saudi Arabia. Int. J. Bot. Stud. 2016, 2, 38-59.

87. Rad, J.S.; Alfatemi, M.H.; Rad, M.S.; Sen, D.J. Phytochemical and antimicrobial evaluation of the essential oils and antioxidant activity of aqueous extracts from flower and stem of Sinapis arvensis L. Open J. Adv. Drug Deliv. 2013, 1, 1-10.

88. Al-Qudah, M.A.; Abu Zarga, M.H. Chemical composition of essential oils from aerial parts of Sisymbrium irio from Jordan. J. Chem. 2010, 7, 6-10.

89. Yousif, F.; Wassel, G.; Boulos, L.; Labib, T.; Mahmoud, K.; El-Hallouty, S.; El-Manawaty, M. Contribution to in vitro screening of Egyptian plants for schistosomicidal activity. Pharm. Biol. 2012, 50, 732-739. [CrossRef] [PubMed] 
90. Kulisic-Bilusic, T.; Schmöller, I.; Schnäbele, K.; Siracusa, L.; Ruberto, G. The anticarcinogenic potential of essential oil and aqueous infusion from caper (Capparis spinosa L.). Food Chem. 2012, 132, 261-267. [CrossRef]

91. Jovanović, M.; Mimica-Dukić, N.; Poljački, M.; Boža, P. Erythema multiforme due to contact with weeds: A recurrence after patch testing. Contact Dermat. 2003, 48, 17-25. [CrossRef]

92. Ogunwande, I.A.; Flamini, G.; Adefuye, A.E.; Lawal, N.O.; Moradeyo, S.; Avoseh, N.O. Chemical compositions of Casuarina equisetifolia L. Eucalyptus toreliana L. and Ficus elastica Roxb. ex Hornem cultivated in Nigeria. S. Afr. J. Bot. 2011, 77, 645-649. [CrossRef]

93. Essien, E.E.; Newby, J.M.; Walker, T.M.; Ogunwande, I.A.; Setzer, W.N.; Ekundayo, O. Essential oil constituents, anticancer and antimicrobial activity of Ficus mucoso and Casuarina equisetifolia leaves. Am. J. Essent. Oil 2016, 4, 1-06.

94. Javidnia, K.; Nasiri, A.; Miri, R.; Jamalian, A. Composition of the essential oil of Helianthemum kahiricum Del. from Iran. J. Essent. Oil Res. 2007, 19, 52-53. [CrossRef]

95. Shahin, S.M.; Kurup, S.; Cheruth, J.; Lennartz, F.; Salem, M. Growth, yield, and physiological responses of Cleome amblyocarpa Barr. \& Murb. under varied irrigation levels in sandy soils. J. Food Agric. Environ. 2018, 16, 124-134.

96. Rassouli, E.; Dadras, O.G.; Bina, E.; Asgarpanah, J. The essential oil composition of Cleome brachycarpa Vahl ex DC. J. Essent. Oil Bear. Plants 2014, 17, 158-163. [CrossRef]

97. Abd El-Gawad, A.M.; El-Amier, Y.A.; Bonanomi, G. Essential oil composition, antioxidant and allelopathic activities of Cleome droserifolia (Forssk.) Delile. Chem. Biodivers. 2018, 15, e1800392. [CrossRef] [PubMed]

98. Anbazhagi, T.; Kadavul, K.; Suguna, G.; Petrus, A.J.A. Studies on the pharmacognostical and in vitro antioxidant potential of Cleome gynandra Linn. leaves. Nat. Prod. Rad. 2009, 8, 151-157.

99. Owolabi, M.S.; Lawal, O.A.; Ogunwande, I.A.; Hauser, R.M.; Setzer, W.N. Chemical composition of the leaf essential oil of Terminalia catappa L. growing in Southwestern Nigeria. Am. J. Essent. Oil 2013, 1, 51-54.

100. Böhme, M.; Pinker, I. Investigation regarding the potential for cultivation of indigenous vegetables in Southeast Asia. Acta Hortic. 2006, 752, 179-186. [CrossRef]

101. Al-Harbi, N.O. Effect of marjoram extract treatment on the cytological and biochemical changes induced by cyclophosphamide in mice. J. Med. Plant Res. 2011, 5, 5479-5485.

102. Joshi, R.K. Sesquiterpene-rich volatile constituents of Ipomoea obscura (L.) Ker-Gawl. Nat. Prod. Res. 2015, 29, 1935-1937. [CrossRef] [PubMed]

103. Fernando, L.N.; Grün, I.U. Headspace-SPME analysis of volatiles of the ridge gourd (Luffa acutangula) and bitter gourd (Momordica charantia) flowers. Flavour Fragr. J. 2001, 16, 289-293. [CrossRef]

104. Braca, A.; Siciliano , T.; D’Arrigo, M.; Germanò, M.P. Chemical composition and antimicrobial activity of Momordica charantia seed essential oil. Fitoterapia 2008, 79, 123-125. [CrossRef]

105. Govindarajan, M.; Sivakumar, R.; Rajeswary, M.; Yogalakshmi, K. Chemical composition and larvicidal activity of essential oil from Ocimum basilicum (L.) against Culex tritaeniorhynchus, Aedes albopictus and Anopheles subpictus (Diptera: Culicidae). Exp. Parasitol. 2013, 134, 7-11. [CrossRef] [PubMed]

106. Feizbakhsh, A.; Aghassi, A.; Naeemy, A. Chemical constituents of the essential oils of Cyperus difformis L. and Cyperus arenarius Retz from Iran. J. Essent. Oil Bear. Plants 2012, 15, 48-52. [CrossRef]

107. Hisham, A.; Rameshkumar, K.B.; Sherwani, N.; Al-Saidi, S.; Al-Kindy, S. The composition and antimicrobial activities of Cyperus conglomeratus, Desmos chinensis var. lawii and Cyathocalyx zeylanicus essential oils. Nat. Prod. Commun. 2012, 7, 663-666. [CrossRef] [PubMed]

108. Hu, Q.P.; Cao, X.M.; Hao, D.L.; Zhang, L.L. Chemical composition, antioxidant, DNA damage protective, cytotoxic and antibacterial activities of Cyperus rotundus rhizomes essential oil against foodborne pathogens. Sci. Rep. 2017, 7, 1-9. [CrossRef] [PubMed]

109. Zhu, Q.; Jiang, M.L.; Shao, F.; Ma, G.Q.; Shi, Q.; Liu, R.H. Chemical composition and antimicrobial activity of the essential oil from Euphorbia helioscopia L. Nat. Prod. Commun. 2020, 15, 1934578X20953249. [CrossRef]

110. Ogunlesi, M.; Okiei, W.; Ofor, E.; Osibote, A.E. Analysis of the essential oil from the dried leaves of Euphorbia hirta Linn (Euphorbiaceae), a potential medication for asthma. Afr. J. Biotechnol. 2009, 8, 7042-7050.

111. Lin, J.; Dou, J.; Xu, J.; Aisa, H.A. Chemical composition, antimicrobial and antitumor activities of the essential oils and crude extracts of Euphorbia macrorrhiza. Molecules 2012, 17, 5030-5039. [CrossRef]

112. Salem, N.; Bachrouch, O.; Sriti, J.; Msaada, K.; Khammassi, S.; Hammami, M.; Selmi, S.; Boushih, E.; Koorani, S.; Abderraba, M.; et al. Fumigant and repellent potentials of Ricinus communis and Mentha pulegium essential oils against Tribolium castaneum and Lasioderma serricorne. Int. J. Food Prop. 2017, 20 (Suppl. S3), S2899-S2913. [CrossRef]

113. Samejo, M.Q.; Memon, S.; Bhanger, M.I.; Khan, K.M. Chemical composition of essential oils from Alhagi maurorum. Chem. Nat. Comp. 2012, 48, 898-900. [CrossRef]

114. Hassanshahian, M.; Saadatfar, A.; Masoumipour, F. Formulation and characterization of nanoemulsion from Alhagi maurorum essential oil and study of its antimicrobial, antibiofilm, and plasmid curing activity against antibiotic-resistant pathogenic bacteria. J. Environ. Health Sci. Eng. 2020, 18, 1-13. [CrossRef]

115. Sabudak, T.; Goren, A.C. Volatile Composition of Trifolium and Medicago Species. J. Essent. Oil Bear. Plants 2011, 14, 401-407. [CrossRef] 
116. Gweru, N.; Gundidza, M.; Magwa, M.L.; Ramalivhana, N.J.; Humphrey, G.; Samie, A.; Mmbengwa, V. Phytochemical composition and biological activities of essential oil of Rhynchosia minima (L) (DC) (Fabaceae). Afr. J. Biotechnol. 2009, 8, 721-724.

117. Jia, X.; Zhang, C.; Qiu, J.; Wang, L.; Bao, J.; Wang, K.; Han, J. Purification, structural characterization and anticancer activity of the novel polysaccharides from Rhynchosia minima root. Carbohydr. Polym. 2015, 132, 67-71. [CrossRef]

118. Hamed Chitsazan, M.; Bina, E.; Asgarpanah, J. Essential oil composition of the endemic species Tephrosia persica Boiss. J. Essent. Oil Res. 2014, 26, 141-145. [CrossRef]

119. Al-Qudah, M.A.; Al-Ghoul, A.M.; Trawenh, I.N.; Al-Jaber, H.I.; Al Shboul, T.M.; Abu Zarga, M.H.; Abu orabi, S.T. Antioxidant Activity and Chemical Composition of Essential Oils from Jordanian Ononis natrix L. and Ononis sicula Guss. J. Biol. Active Prod. Nat. 2014, 4, 52-61.

120. Ogunbinu, A.O.; Okeniyi, S.; Flamini, G.; Cioni, P.L.; Ogunwande, I.A.; Babalola, I.T. Essential oil composition of Acacia nilotica Linn., and Acacia albida Delile (Leguminosae) from Nigeria. J. Essen. Oil Res. 2010, 22, 540-542. [CrossRef]

121. Vivekanandhan, P.; Venkatesan, R.; Ramkumar, G.; Karthi, S.; Senthil-Nathan, S.; Shivakumar, M.S. Comparative analysis of major mosquito vectors response to seed-derived essential oil and seed pod-derived extract from Acacia nilotica. Int. J. Environ. Res. 2018, 15, 388. [CrossRef] [PubMed]

122. Ogunwande, I.A.; Matsui, T.; Matsumoto, K.; Shimoda, M.; Kubmarawa, D. Constituents of the essential oil from the leaves of Acacia tortilis (Forsk.) Hayne. J. Essent. Oil Res. 2008, 20, 116-119. [CrossRef]

123. Harzallah-Skhiri, F.; Jannet, H.B.; Hammami, S.; Mighri, Z. Variation of volatile compounds in two Prosopis farcta (Banks et Sol.) Eig.(Fabales, Fabaceae $=$ Leguminosae) populations. Flavour Fragr. J. 2006, 21, 484-487. [CrossRef]

124. Chaieb, I. Research on insecticidal plants in Tunisia: Review and discussion of methodological approaches. Tunis. J. Plant Prot. 2011, 6, 109-125.

125. Ljoljić Bilić, V.; Stabentheiner, E.; Kremer, D.; Dunkić, V.; Grubešić, R.J.; Rodríguez, J.V. Phytochemical and micromorphological characterization of croatian populations of Erodium cicutarium. Nat. Prod. Commun. 2019, 14, 1934578X19856257. [CrossRef]

126. Morshedloo, M.R.; Ebadi, A.; Maggi, F.; Fattahi, R.; Yazdani, D.; Jafari, M. Chemical characterization of the essential oil compositions from Iranian populations of Hypericum perforatum L. Ind. Crops Prod. 2015, 76, 565-573. [CrossRef]

127. Al-Qudah, M.A.; Saleh, A.M.; Al-Jaber, H.I.; Tashtoush, H.I.; Lahham, J.N.; Zarga, M.H.A.; Orabi, S.T.A. New isoflavones from Gynandriris sisyrinchium and their antioxidant and cytotoxic activities. Fitoterapia 2015, 107, 15-21. [CrossRef]

128. Sharifi-Rad, J.; Hoseini-Alfatemi, S.M.; Sharifi-Rad, M.; Setzer, W.N. Chemical composition, antifungal and antibacterial activities of essential oil from Lallemantia royleana (Benth. In Wall.) Benth. J. Food Saf. 2015, 35, 19-25. [CrossRef]

129. Bardaweel, S.K.; Bakchiche, B.; ALSalamat, H.A.; Rezzoug, M.; Gherib, A.; Flamini, G. Chemical composition, antioxidant, antimicrobial and Antiproliferative activities of essential oil of Mentha spicata L.(Lamiaceae) from Algerian Saharan atlas. BMC Complement. Altern. Med. 2018, 18, 201. [CrossRef]

130. Al-Marzouqi, A.H.; Rao, M.V.; Jobe, B. Comparative evaluation of SFE and steam distillation methods on the yield and composition of essential oil extracted from spearmint (Mentha spicata). J. Liq. Chromatogr. Relat. Technol. 2007, 30, 463-475. [CrossRef]

131. Dekker, T.; Ignell, R.; Ghebru, M.; Glinwood, R.; Hopkins, R. Identification of mosquito repellent odours from Ocimum forskolei. Parasites Vectors 2011, 4, 183. [CrossRef]

132. Pourhosseini, M.; Asgarpanah, J. Essential and fixed oil chemical profiles of Salvia aegyptiaca L. Flowers and seeds. J. Chil. Chem. Soc. 2015, 60, 2747-2748. [CrossRef]

133. Mirzania, F.; Sarrafi, Y.; Farimani, M.M. Comparison of chemical composition, antifungal antibacterial activities of two populations of Salvia macilenta Boiss. Essential oil. Rec. Nat. Prod. 2018, 12, 385-390. [CrossRef]

134. Rajabi, Z.; Ebrahimi, M.; Farajpour, M.; Mirza, M.; Ramshini, H. Compositions and yield variation of essential oils among and within nine Salvia species from various areas of Iran. Ind. Crops Prod. 2014, 61, 233-239. [CrossRef]

135. Zomorodian, K.; Moein, M.; Pakshir, K.; Karami, F.; Sabahi, Z. Chemical composition and antimicrobial activities of the essential oil from Salvia mirzayanii leaves. J. Evid. Based Complement. Altern. Med. 2017, 22, 770-776. [CrossRef]

136. Flamini, G.; Cioni, P.L.; Morelli, I.; Bader, A. Essential oils of the aerial parts of three Salvia species from Jordan: Salvia lanigera, S. spinosa and S. syriaca. Food Chem. 2007, 100, 732-735. [CrossRef]

137. Cozzani, S.; Muselli, A.; Desjobert, J.M.; Bernardini, A.F.; Tomi, F.; Casanova, J. Chemical composition of essential oil of Teucrium polium subsp. capitatum (L.) from Corsica. Flavour Fragr. J. 2005, 20, 436-441. [CrossRef]

138. Kabudari, A.; Mahalleh, S.F.R.P. Study of antibacterial effects of Teucrium polium essential oil on Bacillus cereus in cultural laboratory and commercial soup. Carpathian Food Sci. Technol. 2016, 8, 176-183.

139. Sonboli, A.; Bahadori, M.B.; Dehghan, H.; Aarabi, L.; Savehdroudi, P.; Nekuei, M.; Pournaghi, N.; Mirzania, F. Chemotaxonomic Importance of the Essential-Oil Composition in Two Subspecies of Teucrium stocksianum Boiss. from Iran. Chem. Biodivers. 2013, 10, 687-694. [CrossRef] [PubMed]

140. Misaghi, A.; Basti, A.A. Effects of Zataria multiflora Boiss. essential oil and nisin on Bacillus cereus ATCC 11778. Food Control 2007, 18, 1043-1049. [CrossRef]

141. Mahboubi, M.; Bidgoli, F.G. Antistaphylococcal activity of Zataria multiflora essential oil and its synergy with vancomycin. Phytomedicine 2010, 17, 548-550. [CrossRef]

142. El-Shabrawy, M.O.; Marzouk, M.M.; Kawashty, S.A.; Hosni, H.A.; El Garf, I.A.; Saleh, N.A.M. Flavonoid constituents of Dipcadi erythraeum Webb. \& Berthel. Asian Pac. J. Trop. Dis. 2016, 6, 404-405. 
143. Satyal, P.; Paudel, P.; Poudel, A.; Setzer, W.N. Antimicrobial activities and constituents of the leaf essential oil of Lawsonia inermis growing in Nepal. Pharmacol. OnLine 2012, 1, 31-35.

144. Ahmad, F. GIS, GPS and remote sensing application to investigate agricultural potential in Cholistan. Soc. Nat. 2007, 19, 55-64.

145. Chaves, T.P.; Pinheiro, R.E.E.; Melo, E.S.; Soares, M.J.D.S.; Souza, J.S.N.; de Andrade, T.B.; Telma, L.; Gomes, L.; Coutinho, H.D Essential oil of Eucalyptus camaldulensis Dehn potentiates $\beta$-lactam activity against Staphylococcus aureus and Escherichia coli resistant strains. Ind. Crops Prod. 2018, 112, 70-74. [CrossRef]

146. Barra, A.; Coroneo, V.; Dessi, S.; Cabras, P.; Angioni, A. Chemical variability, antifungal and antioxidant activity of Eucalyptus camaldulensis essential oil from Sardinia. Nat. Prod. Commun. 2010, 5, 329-335. [CrossRef]

147. Younis, A.; Mehdi, A.; Riaz, A. Supercritical carbon dioxide extraction and gas chromatography analysis of Jasminum sambac essential oil. Pak. J. Bot. 2011, 43, 163-168.

148. Mukesi, M.; Iweriebor, B.C.; Obi, L.C.; Nwodo, U.U.; Moyo, S.R.; Okoh, A.I. The activity of commercial antimicrobials, and essential oils and ethanolic extracts of Olea europaea on Streptococcus agalactiae isolated from pregnant women. BMC Complement. Altern. Med. 2019, 19, 34. [CrossRef]

149. Middleditch, B.S. Kuwaiti Plants: Distribution, Traditional Medicine, Pytochemistry, Pharmacology and Economic Value; Elsevier: New York, NY, USA, 2012; Volume 2.

150. Artizzu, N.; Bonsignore, L.; Cottiglia, F.; Loy, G. Studies on the diuretic and antimicrobial activity of Cynodon dactylon essential oil. Fitoterapia 1996, 67, 174-176.

151. Arjunan, N.; Murugan, K.; Madhiyazhagan, P.; Kovendan, K.; Prasannakumar, K.; Thangamani, S.; Barnard, D.R. Mosquitocidal and water purification properties of Cynodon dactylon, Aloe vera, Hemidesmus indicus and Coleus amboinicus leaf extracts against the mosquito vectors. Parasitol. Res. 2012, 110, 1435-1443. [CrossRef]

152. Vasilakoglou, I.; Dhima, K.; Paschalidis, K.; Ritzoulis, C. Herbicidal potential on Lolium rigidum of nineteen major essential oil components and their synergy. J. Essent. Oil Res. 2013, 25, 1-10. [CrossRef]

153. Llewellyn, R.S.; D'emden, F.H.; Owen, M.J.; Powles, S.B. Herbicide resistance in rigid ryegrass (Lolium rigidum) has not led to higher weed densities in Western Australian cropping fields. Weed Sci. 2009, 57, 61-65. [CrossRef]

154. Abu-Rabia, A. Ethnobotany among Bedouin Tribes in the Middle East. In Medicinal and Aromatic Plants of the Middle-East; Springer: Dordrech, The Netherlands, 2014; pp. 27-36.

155. Khanuja, S.P.; Shasany, A.K.; Pawar, A.; Lal, R.K.; Darokar, M.P.; Naqvi, A.A.; Kumar, S. Essential oil constituents and RAPD markers to establish species relationship in Cymbopogon Spreng.(Poaceae). Biochem. Syst. Ecol. 2005, 33, 171-186. [CrossRef]

156. Hashim, G.M.; Almasaudi, S.B.; Azhar, E.; Al Jaouni, S.K.; Harakeh, S. Biological activity of Cymbopogon schoenanthus essential oil. Saudi J. Biol. Sci. 2017, 24, 1458-1464. [CrossRef]

157. Samejo, M.Q.; Memon, S.; Bhanger, M.I.; Khan, K.M. Chemical composition of essential oil from Calligonum polygonoides Linn. Nat. Prod. Res. 2013, 27, 619-623. [CrossRef]

158. Samejo, M.Q.; Memon, S.; Bhanger, M.I.; Khan, K.M. Essential oil constituents in fruit and stem of Calligonum polygonoides. Ind. Crops Prod. 2013, 45, 293-295. [CrossRef]

159. Soliman, S.S.M.; Alsaadi, A.I.; Youssef, E.G.; Khitrov, G.; Noreddin, A.M.; Husseiny, M.I.; Ibrahim, A.S. Calli Essential Oils Synergize with Lawsone against Multidrug Resistant Pathogens. Molecules 2017, 22, 2223. [CrossRef] [PubMed]

160. Elfotoh, M.A.; Shams, K.A.; Anthony, K.P.; Shahat, A.A.; Ibrahim, M.T.; Abdelhady, N.M.; Azim, N.S.; Hammouda, F.M.; El-Missiry, M.M.; Saleh, M.A. Lipophilic Constituents of Rumex vesicarius L. and Rumex dentatus L. Antioxidans 2013, 2, 167-180. [CrossRef]

161. Harzallah, H.J.; Kouidhi, B.; Flamini, G.; Bakhrouf, A.; Mahjoub, T. Chemical composition, antimicrobial potential against cariogenic bacteria and cytotoxic activity of Tunisian Nigella sativa essential oil and thymoquinone. Food Chem. 2011, 129, 1469-1474. [CrossRef]

162. Xue, Z.; Feng, W.; Cao, J.; Cao, D.; Jiang, W. Antioxidant activity and total phenolic contents in peel and pulp of Chinese jujube (Ziziphus jujuba Mill) fruits. J. Food Biochem. 2009, 33, 613-629. [CrossRef]

163. Ghannadi, A.; Tavakoli, N.; Mehri-Ardestani, M. Volatile constituents of the leaves of Ziziphus spina-christi (L.) Willd. from Bushehr, Iran. J. Essen. Oil Res. 2003, 15, 191-192. [CrossRef]

164. Jan, A.K.; Anis, I.; Shah, M.R. Chemical Composition and Antifungal Activity of the Essential Oil of Galium tricornutum subsp. longipedanculatum from Pakistan. Chem. Nat. Compd. 2015, 51, 164-165. [CrossRef]

165. Al-Rehaily, A.J.; Alqasoumi, S.I.; Yusufoglu, H.S.; Al-Yahya, M.A.; Demirci, B.; Tabanca, N.; Wedge, D.E.; Demirci, F.; Bernier, U.R.; Becnel, J.J.; et al. Chemical Composition and biological activity of Haplophyllum tuberculatum Juss. essential oil. J. Essent. Oil Bear. Plants 2014, 17, 452-459. [CrossRef]

166. Tampe, J.; Parra, L.; Huaiquil, K.; Quiroz, A. Potential repellent activity of the essential oil of Ruta chalepensis (Linnaeus) from Chile against Aegorhinus superciliosus (Guérin) (Coleoptera: Curculionidae). J. Soil Sci. Plant Nutr. 2016, 16, 48-59. [CrossRef]

167. Alali, F.; Hudaib, M.; Aburjai, T.; Khairallah, K.; Al-Hadidi, N. GC-MS Analysis and Antimicrobial Activity of the Essential Oil from the Stem of the Jordanian Toothbrush Tree Salvadora persica. Pharm. Biol. 2005, 42, 577-580. [CrossRef]

168. Sofrata, A.; Santangelo, E.M.; Azeem, M.; Borg-Karlson, A.K.; Gustafsson, A.; Pütsep, K. Benzyl isothiocyanate, a major component from the roots of Salvadora persica is highly active against Gram-negative bacteria. PLoS ONE 2011, 6, e23045. [CrossRef]

169. Mehrotra, V.; Mehrotra, S.; Kirar, V.; Shyam, R.; Misra, K.; Srivastava, A.K.; Nandi, S.P. Antioxidant and antimicrobial activities of aqueous extract of Withania somnifera against methicillin-resistant Staphylococcus aureus. J. Microbiol. Biotechnol. Res. 2017, 1, 40-45. 
170. AbouZid, S.; Elshahaat, A.; Ali, S.; Choudhary, M.I. Antioxidant activity of wild plants collected in Beni-Sueif governorate, Upper Egypt. Drug Discov. Ther. 2008, 2, 286-288. [PubMed]

171. Li, D.H.; Wang, Z.; Liang, Z.Y.; Yang, X.B.; Xu, J. Comparative evaluation of the chemical composition of essential oil from twig, leaf and root of Clerodendrum inerme (L.). Gaertn. Adv. Mat. Res. 2012, 343, 22-27. [CrossRef]

172. Deena, M.J.; Thoppil, J.E. Antimicrobial activity of the essential oil of Lantana camara. Fitoterapia 2000, 71, 453-455. [CrossRef]

173. Sousa, E.O.; Almeida, T.S.; Menezes, I.R.; Rodrigues, F.F.; Campos, A.R.; Lima, S.G.; Costa, J.G. Chemical composition of essential oil of Lantana camara L.(Verbenaceae) and synergistic effect of the aminoglycosides gentamicin and amikacin. Rec. Nat. Prod. 2012, $6,144-150$.

174. Benavides Calvache, O.L.; Villota, J.M.; Milena Tovar, D. Characterization of essential oil present in the leaves of Phyla nodiflora (L.) Greene (OROZUL). Univ. Salud 2010, 12, 57-64.

175. Senatore, F. Della Porta, G.; Reverchon, E. Constituents of Vitex agnus-castus L. Essential Oil Flavour. Fragr. J. 1996, 11, 179-182. [CrossRef]

176. Khalilzadeh, E.; Saiah, G.V.; Hasannejad, H.; Ghaderi, A.; Ghaderi, S.; Hamidian, G.; Mahmoudi, R.; Eshgi, D.; Zangisheh, M. Antinociceptive effects, acute toxicity and chemical composition of Vitex agnus-castus essential oil. Avicenna J. Phytomed. 2015, 5, 218. [PubMed]

177. Huang, L.S.; Zhu, F.; Huang, M.Z. GC/MS analysis of the chemical constituents of the essential oil from the fruits of Avicennia marina. Fine Chem. 2009, 3, 11.

178. Akhbari, M.; Batooli, H.; Kashi, F.J. Composition of essential oil and biological activity of extracts of Viola odorata L. from central Iran. Nat. Prod. Res. 2012, 26, 802-809. [CrossRef] [PubMed]

179. Abdel-Rahim, I.R. Control of Alternaria rot disease of pear fruits using essential oil of Viola odorata. J. Phytopathol. Pest Manag. 2016, 3, 71-84.

180. Charles, D.J.; Simon, J.E.; Singh, N.K. The essential oil of Alpinia galanga Willd. J. Essent. Oil Res. 1992, 4, 81-82. [CrossRef]

181. Wu, Y.; Wang, Y.; Li, Z.; Wang, C.; Wei, J.; Li, X.; Wang, P.; Zhou, Z.; Huang, D.; Deng, Z. Composition of the essential oil from Alpinia galanga rhizomes and its bioactivity on Lasioderma serricorne. Bull. Insectol. 2014, 67, 247-254.

182. Das, A.; Dey, S.; Sahoo, R.K.; Sahoo, S.; Subudhi, E. Antibiofilm and antibacterial activity of essential oil bearing Zingiber officinale Rosc.(Ginger) Rhizome against multi-drug resistant isolates. J. Essent. Oil Bear. Plants 2019, 22, 1163-1171. [CrossRef]

183. Yang, S.; Bai, M.; Yang, J.; Yuan, Y.; Zhang, Y.; Qin, J.; Kuang, Y.; Sampietro, D.A. Chemical composition and larvicidal activity of essential oils from Peganum harmala, Nepeta cataria and Phellodendron amurense against Aedes aegypti (Diptera: Culicidae). Saudi Pharm. J. 2020, 28, 560-564. [CrossRef] [PubMed]

184. Fraga, B.M. Natural sesquiterpenoids. Nat. Prod. Rep. 2006, 23, 943-972. [CrossRef]

185. Raut, J.S.; Karuppayil, S.M. A status review on the medicinal properties of essential oils. Ind. Crops Prod. 2014, 62, 250-264. [CrossRef]

186. Sajjadi, S.E.; Ghassemi, N.; Shokoohinia, Y.; Moradi, H. Essential oil composition of flowers of Anthemis odontostephana Boiss. var. odontostephana. J. Essent. Oil Bear. Plants 2013, 16, 247-251. [CrossRef]

187. Ezazi, A.; Rahchamani, N.; Ghahremaninejad, F. The flora of Saluk National Park, Northern Khorassan province, Iran. J. Biodivers. Environ. Sci. 2014, 5, 45-71.

188. Rabie, M.; Asri, Y.; Hamzehee, B.; Jalili, A.; Sefidkon, F. Determination of chemotaxonomic indices of Artemisia sieberi Besser based on environmental parameters in Iran. Iran. J. Bot. 2012, 18, 149-157.

189. Paolini, J.; Barboni, T.; Desjobert, J.M.; Djabou, N.; Muselli, A.; Costa, J. Chemical composition, intraspecies variation and seasonal variation in essential oils of Calendula arvensis L. Biochem. Syst. Ecol. 2010, 38, 865-874. [CrossRef]

190. Nandagopal, S.; Ranjitha Kumari, B.D. Adenine sulphate induced high frequency shoot organogenesis in callus and in vitro flowering of Cichorium intybus L. cv. Focus-a potent medicinal plant. Acta Agric. Slov. 2006, 87, 415-425.

191. Mabrouk, S.; Elaissi, A.; Ben Jannet, H.; Harzallah-Skhiri, F. Chemical composition of essential oils from leaves, stems, flower heads and roots of Conyza bonariensis L. from Tunisia. Nat. Prod. Res. 2011, 25, 77-84. [CrossRef]

192. Soares, A.A.F.; Fregonezi, A.M.D.T.; Bassi, D.; Mangolin, C.A.; de Oliviera Collet, S.A.; de Oliveira Junior, R.S.; da Silva, M.d.F.P. Evidence of high gene flow between samples of horseweed (Conyza canadensis) and hairy fleabane (Conyza bonariensis) as revealed by isozyme polymorphisms. Weed Sci. 2015, 63, 604-612. [CrossRef]

193. Sadeghi, Z.; Kuhestani, K.; Abdollahi, V.; Mahmood, A. Ethnopharmacological studies of indigenous medicinal plants of Saravan region: Baluchistan Iran. J. Ethnopharmacol. 2014, 153, 111-118. [CrossRef]

194. Louhaichi, M.; Salkini, A.K.; Estita, H.E.; Belkhir, S. Initial assessment of medicinal plants across the Libyan Mediterranean coast. Adv. Environ. Biol. 2011, 5, 359-370.

195. Roby, M.H.H.; Sarhan, M.A.; Selim, K.A.H.; Khalel, K.I. Antioxidant and antimicrobial activities of essential oil and extracts of fennel (Foeniculum vulgare L.) and chamomile (Matricaria chamomilla L.). Ind. Crop. Prod. 2013, 44, 437-445. [CrossRef]

196. EL-Kamali, H.H.; Yousif, M.O.; Ahmed, O.I.; Sabir, S.S. Phytochemical analysis of the essential oil from aerial parts of Pulicaria undulata (L.) Kostel from Sudan. Ethnobot. Leafl. 2009, 13, 467-471.

197. Nematollahi, F.; Rustaiyan, A.; Larijani, K.; Nadimi, M.; Masoudi, S. Essential oil composition of Artemisia biennisz Willd. and Pulicaria undulata (L.) CA Mey.: Two compositae herbs growing wild in Iran. J. Essent. Oil Res. 2006, 18, 339-341. [CrossRef] 
198. Ali, A.; Demirci, B.; Kiyan, H.T.; Bernier, U.R.; Tsikolia, M.; Wedge, D.E.; Khan, I.; Baser, K.; Tabanca, N. Biting deterrence, repellency, and larvicidal activity of Ruta chalepensis (Sapindales: Rutaceae) essential oil and its major individual constituents against mosquitoes. J. Med. Entomol. 2013, 50, 1267-1274. [CrossRef] [PubMed]

199. Znini, M.; Bouklah, M.; Majidi, L.; Kharchouf, S.; Aouniti, A.; Bouyanzer, A.; Hammouti, B.; Costa, J.; Al-Deyab, S.S. Chemical composition and inhibitory effect of Mentha spicata essential oil on the corrosion of steel in molar hydrochloric acid. Int. J. Electrochem. Sci. 2011, 6, 691-704.

200. Ziaei, A.; Ramezani, M.; Wright, L.; Paetz, C.; Schneider, B.; Amirghofran, Z. Identification of spathulenol in Salvia mirzayanii and the immunomodulatory effects. Phytother. Res. 2011, 25, 557-562. [CrossRef] [PubMed] 